\title{
JURISPRUDÊNCIA E EMENTÁRIO
}

JURISPRUDENCE AND ABRIDGEMENT OF LAW

\section{BRASIL}

DIREITO PÚBLICO SANITÁRIO. CONSTITUCIONAL. ANS. UNIMED Regional Nova Friburgo - Cooperativa de Trabalho Médico interpõe recurso extraordinário fundado na alínea "a" do permissivo constitucional contra acórdão do Tribunal Regional Federal da 2a ${ }^{a}$ Região, assim ementado: TRIBUTÁRIO. APELAÇÃO EM MANDADO DE SEGURANÇA. TAXA DE SAÚDE SUPLEMENTAR - TSS. LEI N. 9.961/2000. CONSTITUCIONALIDADE E LEGALIDADE DA TSS. ARTIGOS 196 E 197 DA CONSTITUIÇÃO FEDERAL. LEIS DE N. 9.656/98 E DE N. 9.961/2000. PODER DE POLÍCIA. ART. 192, INCISO II, DA CONSTITUIÇÃO FEDERAL. A questão dos autos gira em torno da constitucionalidade e da legalidade da Taxa de Saúde Suplementar - TSS, instituída pela Lei n. 9.961/2000. A Constituição e de acordo com o seu art. 196, a saúde é um direito de todos e dever do Estado. O art. 197, da Carta Magna dispõe que são de relevância pública as ações e serviços de saúde, cabendo ao Poder Público dispor, nos termos da lei, sobre sua regulamentação, fiscalização e controle, devendo sua execução ser feita diretamente ou através de terceiros e, também, por pessoa física ou jurídica de direito privado. Foram promulgadas a Lei n. 9.656/1998, que dispôs sobre os planos e seguros privados de assistência à saúde, e a Lei n. 9.961/2000, que criou a Agência Nacional de Saúde Suplementar - ANS. Não merece prosperar a questão da inconstitucionalidade decorrente da interferência estatal no funcionamento das cooperativas, conforme arguido pela Apelante. Inexiste qualquer afronta ao princípio da livre-iniciativa - parágrafo único, do art. 170, da CF. As Leis de n. 9.656/98 e de n. 9.961/2000, dizem respeito à lei abstratamente prevista no final do parágrafo único do referido dispositivo constitucional. O art. 174 da Constituição Federal respalda o poder de intervenção do Estado na ordem econômica, uma vez que outorga ao Estado a função de fiscalização, do incentivo e do planejamento das atividades econômicas. Não merece acolhida a questão de afronta ao art. 199, da Constituição Federal. Prosseguindo, mister se faz a análise do exercício do poder de polícia pela Agência Nacional de Saúde Suplementar - ANS, legitimando a instituição das referidas Taxas de Saúde Suplementar. Conforme o disposto no art. 145, inciso II, 
da Constituição Federal e no art. 77, do Código Tributário Nacional, a Taxa é uma espécie de tributo que tem como fato gerador o exercício regular do poder de polícia. Não há que se falar em inexistência de contraprestação para efetivar o exercício do poder de polícia. Não há a exigência de que este poder seja efetivo ou específico. O Poder de Polícia encontra-se bem definido no referido art. 78, do CTN. No que se refere à base de cálculo utilizada no inciso I, do art. 20, da Lei n. 9.961/2000, não há qualquer óbice ao parâmetro utilizado para quantificar o valor da taxa referente ao exercício do poder de polícia, a incidir sobre as operadoras de plano de saúde. Não houve afronta ao art. 192, inciso II, da Constituição Federal (atualmente revogado com a edição de EC 40/2003), uma vez que a MP n. 2.122/2000, convertida na Lei n. 10.185 , de 12 de fevereiro de 2001, somente estabeleceu critérios para a transição das sociedades seguradoras em seguradoras especializadas em planos de saúde, com a consequente transferência da responsabilidade pela regulamentação e fiscalização da SUSEP para a ANS, de modo que não houve a criação de órgão fiscalizador, mas tão somente a transferência de competência anteriormente instituída. Não houve qualquer ofensa ao ato jurídico perfeito e ao direito adquirido. Inexiste qualquer inconstitucionalidade ou ilegalidade, tanto do ponto de vista material, como também, do formal, na cobrança da Taxa de Saúde Suplementar - TSS. Negado provimento à apelação da UNIMED REGIONAL NOVA FRIBURGO - COOPERATIVA DE TRABALHO MÉDICO, e dado provimento à remessa necessária e à apelação da AGÊNCIA NACIONAL DE SAÚDE SUPLEMENTAR - ANS. (fl. 458) No apelo extremo, alega o recorrente contrariedade ao disposto no art. 145, $\S 2$ 을 da Constituição Federal. Sustenta a inconstitucionalidade da Taxa de Saúde Complementar, instituída pela Lei n. 9.961/2000. Contrarrazões, pela União, às fls. 486. Decido. Não merece prosperar a irresignação. A jurisprudência desta Corte tem firme o entendimento no sentido de que para acolher a pretensão da recorrente e ultrapassar o entendimento do Tribunal de origem a respeito da controvérsia que envolve a taxa de saúde suplementar seria necessária a análise de legislação infraconstitucional (Lei n. 9.961/ 2000). Destarte, a alegada violação dos dispositivos constitucionais invocados, se ocorresse, seria indireta ou reflexa, o que não enseja reexame em recurso extraordinário. Nesse sentido, confira-se: AGRAVO REGIMENTAL EM AGRAVO DE INSTRUMENTO. TRIBUTÁRIO. TAXA DE SAÚDE SUPLEMENTAR. LEI N. 9.961/00. MATÉRIA INFRACONSTITUCIONAL. OFENSA INDIRETA. AGRAVO IMPROVIDO. I - A decisão agravada está de acordo com entendimento adotado por ambas as Turmas desta Corte, que consolidaram a jurisprudência no sentido de que a discussão referente à legitimidade da Taxa de Saúde Suplementar, instituída pela Lei n. 9.961/00, depende da análise de norma infraconstitucional e, por isso, a afronta à Constituição, se ocorrente, seria indireta. Precedentes. II - Agravo regimental improvido. (Al 720.733-AgR, Rel. Min. Ricardo Lewandowski, 1a Turma, DJe 8/4/2011) AGRAVO REGIMENTAL EM AGRAVO DE INSTRUMENTO. TAXA DE SAÚDE SUPLEMENTAR. MATÉRIA INFRACONSTITUCIONAL. OFENSA INDIRETA 
OU REFLEXA. O debate sobre a legitimidade da taxa de saúde suplementar demanda exame de legislação infraconstitucional, o que torna inadmissível o recurso extraordinário. Agravo regimental a que se nega provimento. (Al 634.885-AgR, Rel. Min. Joaquim Barbosa, $2^{\text {a }}$ Turma, DJe 30/9/2010). No mesmo sentido: RE 438.047-AgR-AgR, Rel. Min. Ricardo Lewandowski, DJe 22/4/10; Al 505.636-AgR, Rel. Min. Cármen Lúcia, DJe 25/6/09; RE 524.336AgR, Rel. Min. Ellen Gracie, DJe 5/3/09; e Al 496.550-AgR, Rel. Min. Gilmar Mendes, DJe 18/10/07. Ante o exposto, nos termos do art. 557, caput, do Código de Processo Civil, nego seguimento ao recurso extraordinário. Publique-se. Brasília, 18 de abril de 2011. Ministro DIAS TOFFOLI, Relator.

Documento assinado digitalmente

Supremo Tribunal Federal

Processo: RE 524347/RJ - RIO DE JANEIRO RECURSO EXTRAORDINÁRIO

Relator: Dias Toffoli

Julgamento: 18.4.11

DIREITO PÚBLICO SANITÁRIO. POLÍTICA PÚBLICA. FORNECIMENTO DE MEDICAMENTO. Uma das matérias discutidas no presente recurso extraordinário, relativa à obrigatoriedade de o Estado fornecer medicamento de alto custo à pessoa portadora de moléstia grave e o possível comprometimento da assistência à saúde prestada de forma geral, teve sua repercussão geral reconhecida no exame do RE n. 566.471/RN, Relator o Ministro Marco Aurélio, e terá seu mérito oportunamente julgado no Plenário deste Supremo Tribunal Federal. Destarte, determino o sobrestamento do feito até a conclusão do julgamento do mencionado RE n. 566.471/RN. Devem os autos permanecer na Secretaria Judiciária. Publique-se. Brasília, 18 de abril de 2011. Ministro DIAS TOFFOLI, Relator.

Supremo Tribunal Federal

Processo: RE 622611/PB - PARAÍBA RECURSO EXTRAORDINÁRIO Relator: Dias Toffoli

Julgamento: 18.4.11

DIREITO PÚBLICO SANITÁRIO. RESSARCIMENTO AO SUS. Trata-se de embargos de declaração opostos de acórdão que negou provimento ao agravo regimental, sob o fundamento de que o Supremo Tribunal Federal, ao julgar a ADI 1.931-MC/DF, Rel. Min. Maurício Corrêa, entendeu ser constitucional o ressarcimento ao Sistema Único de Saúde - SUS, instituído pelo art. 32 da Lei n. 9.656/1998. Verifica-se que, neste caso, o recurso extraordinário versa sobre matéria cuja repercussão geral já foi reconhecida pelo Supremo Tribunal Federal (RE 597.064-RG/RJ, Rel. Min. Gilmar Mendes). Ademais, o Plenário desta Corte, em 20/8/2008, ao apreciar Questão de Ordem suscitada no RE 540.410/RS, Rel. Min. Cezar Peluso, decidiu estender a aplicação do art. 543-B do Código de Processo Civil aos recursos 
cujo tema constitucional apresente repercussão geral reconhecida pelo Plenário, ainda que interpostos contra acórdãos publicados antes de 3 de maio de 2007. Todavia, observo que não é possível determinar a devolução destes autos ao Tribunal de origem para a observância do disposto no art. 543-B do CPC, tendo em vista que os autos estão em fase de embargos de declaração opostos de acórdão da Primeira Turma. Nessa situação, o processo com recurso pendente de julgamento pelo Colegiado ficará sobrestado nesta Corte, conforme entendimento adotado pela Primeira Turma na Sessão do dia 1\%/2/2011, no julgamento do RE 511.696-AgR-ED-ED/MG, Redator para o acórdão Min. Marco Aurélio. Assim, determino o sobrestamento deste feito na Secretaria do Gabinete até o julgamento do RE 597.064-RG/RJ. Publique-se. Brasília, 13 de abril de 2011. Ministro RICARDO LEWANDOWSKI, Relator.

\section{Supremo Tribunal Federal \\ Processo: RE 595050 AgR-ED/RJ — RIO DE JANEIRO EDCL NO AGRG NO RECURSO EXTRAORDINÁRIO \\ Relator: Ricardo Lewandowsk \\ Julgamento: 13.4.11}

DIREITO SANITÁRIO CONSUMERISTA. PLANO DE SAÚDE. Relatório. 1. Agravo de instrumento contra decisão que não admitiu recurso extraordinário, interposto com base na alínea a do inc. III do art. 102 da Constituição da República. 2. O Tribunal de Justiça de São Paulo julgou apelação em ação ordinária, nos termos seguintes: "APELAÇÃO - Plano de saúde - A legitimidade de parte da operadora de plano de saúde está demonstrada, pois o art. 31 da Lei n. 9.656/98 assegura a manutenção do aposentado como beneficiário do plano e o cumprimento dessa disposição pode ser exigido da empresa prestadora do serviço - A ex-empregadora também é parte legítima para figurar no polo passivo da demanda - Inocorrência de prescrição - Mérito - Aposentadoria de empregado contribuinte - Prova da contribuição durante mais de dez anos - Direito de manutenção do benefício, nos termos do art. 31, 'caput', da Lei n. 9.656/98, desde que assuma o pagamento integral da prestação - Recurso do autor provido e desprovido o da corré (voto 7885)" (fl. 296). Os embargos declaratórios opostos foram assim julgados: "Embargos de declaração - Omissão, obscuridade ou contradição inexistentes - Embargos rejeitados (voto 8848)" (fl. 310). 3. A decisão agravada teve como fundamentos para a inadmissibilidade do recurso extraordinário as circunstâncias de que a ofensa constitucional, se tivesse ocorrido, seria indireta e de que não teria havido contrariedade ao inc. IX do art. 93 da Constituição. 4. A Agravante argumenta, em síntese, que: "demonstrou claramente em seu recurso extraordinário a violação de dispositivos da Constituição Federal pelo v. acórdão recorrido, motivo pelo qual se requer seja dado provimento ao presente agravo, de forma que o recurso extraordinário seja processado e julgado" (fl. 11). No recurso extraordinário, alega que o Tribunal 'a quo' teria contrariado os arts. 5º, inc. II 
e XXXV, e 93, inc. IX, da Constituição. Apreciada a matéria trazida na espécie, DECIDO. 5. Razão jurídica não assiste à Agravante. Anote-se, inicialmente, que, quanto à alegação de nulidade do acórdão por ofensa ao inc. IX do art. 93 da Constituição da República, embora em sentido contrário à pretensão da Agravante, o acórdão recorrido apresentou suficiente fundamentação. E, tal como se firmou na jurisprudência do Supremo Tribunal Federal: "O que a Constituição exige, no art. 93, IX, é que a decisão judicial seja fundamentada; não que a fundamentação seja correta, na solução das questões de fato ou de direito da lide: declinadas no julgado as premissas, corretamente assentadas ou não, mas coerentes com o dispositivo do acórdão, está satisfeita a exigência constitucional" (RE 140.370, Rel. Min. Sepúlveda Pertence, Primeira Turma, DJ 21.5.1993). 6. Registre-se, também, o que observado pelo Desembargador Relator: "No que se refere à legitimidade passiva da ex-empregadora - General Motors do Brasil — esta Colenda Câmara já deixou assentado: 'Sob tal ótica, parece evidente que a empregadora tem papel participativo na oferta de plano de saúde, quer exercendo intermediação entre a prestadora de serviço e seus empregados e ex-empregados, quer propiciando a própria oferta de seguro-saúde, que, finalmente, apresentando as informações pertinentes à aferição da existência ou não do direito, como condições da dispensa, valores pagos e/ou subsidiados, etc. (...) Concluindo, a General Motors é parte legítima para, em princípio, responder pela obrigação de possibilitar a prestação do serviço de saúde, nos moldes existentes ao tempo do vínculo trabalhista, ainda que com a integralidade do custo atribuída ao ex-empregado (...)'. O contrato de plano de saúde teve início em 20.03.76 e, que consta, não sofreu interrupção, restando comprovada a contribuição pelo prazo de dez anos, como exige o art. 31 da Lei n. 9.656/98. Destarte, faz jus à manutenção do plano de saúde, como beneficiário, nas mesmas condições de cobertura vigentes até a data em que foi rescindido o contrato de trabalho, devendo arcar com o valor integral das mensalidades" (fls. 297 e 299). Conforme se verifica, concluir de forma diversa do que foi decidido pelas instâncias originárias demandaria o reexame do conjunto fático-probatório constante dos autos, procedimento incabível de ser adotado validamente em recurso extraordinário, nos termos do que dispõe a Súmula n. 279 deste Supremo Tribunal. O novo exame do julgado impugnado exigiria, ainda, a análise prévia da legislação infraconstitucional aplicada à espécie (Lei $n$. 9.656/1988). Assim, a alegada contrariedade à Constituição da República, se tivesse ocorrido, seria indireta, o que não viabiliza o processamento do recurso extraordinário. Nesse sentido: "CONSUMIDOR. CONTRATO DE PLANO DE SAÚDE. CONTROVÉRSIA DECIDIDA COM FUNDAMENTO NA LEGISLAÇÃO INFRACONSTITUCIONAL. SÚMULAS STF 279 E 454. 1. Concluir de forma diversa do assentado no julgado do Tribunal de origem demandaria a prévia análise de fatos, provas, cláusulas contratuais (Súmulas STF 279 e 454) e da legislação infraconstitucional aplicável à espécie (CDC e Lei n. 9.656/98), hipóteses inviáveis em sede extraordinária. Precedentes. 
2. Agravo regimental improvido" (Al 761.879-AgR, Rel. Min. Ellen Gracie, Segunda Turma, DJe 24.9.2010 - grifei). 7. Ressalte-se, ao final, que este Supremo Tribunal assentou que a alegação de contrariedade ao princípio da legalidade e a verificação, no caso concreto, da ocorrência, ou não, de ofensa ao direito adquirido, ao ato jurídico perfeito, à coisa julgada ou, ainda, aos princípios do devido processo legal, da ampla defesa, do contraditório e da prestação jurisdicional, se dependentes de análise prévia da legislação infraconstitucional, configurariam apenas ofensa constitucional indireta. Nesse sentido: "AGRAVO REGIMENTAL EM AGRAVO DE INSTRUMENTO. ALEGADA VIOLAÇÃO AOS PRINCÍPIOS DA AMPLA DEFESA, DO CONTRADITÓRIO E DO DEVIDO PROCESSO LEGAL E DO DIREITO ADQUIRIDO. MATÉRIA INFRACONSTITUCIONAL. OFENSA INDIRETA. INEXISTÊNNCIA DE OFENSA AO ART. 93, IX, DA CARTA MAGNA. ACORDÃO SUFICIENTEMENTE FUNDAMENTADO. AGRAVO IMPROVIDO. I - A jurisprudência desta Corte fixou-se no sentido de que a afronta aos princípios do devido processo legal, da ampla defesa, do contraditório, do direito adquirido, dos limites da coisa julgada e da prestação jurisdicional, se dependente de reexame prévio de normas infraconstitucionais, em regra, seria indireta ou reflexa. Precedentes. II - A exigência do art. 93, IX, da Constituição, não impõe que seja a decisão exaustivamente fundamentada. $\mathrm{O}$ que se busca é que o julgador informe de forma clara e concisa as razões de seu convencimento. III - Agravo regimental improvido" (Al 816.034-AgR, Rel. Min. Ricardo Lewandowski, Primeira Turma, DJe 23.2.2011 - grifei). A decisão agravada, embasada nos dados constantes do acórdão recorrido, está em harmonia com a jurisprudência deste Supremo Tribunal, razão pela qual nada há a prover quanto às alegações da Agravante. 8. Pelo exposto, nego seguimento a este agravo de instrumento (art. 557, 'caput', do Código de Processo Civil e art. 21, § 1ㅇ, do Regimento Interno do Supremo Tribunal Federal). Publique-se. Brasília, 13 de abril de 2011. Ministra CÁRMEN LÚCIA, Relatora.

\section{Supremo Tribunal Federal \\ Processo: Al 770037 / SP — SÃO PAULO AGRAVO DE INSTRUMENTO Relatora: Cármen Lúcia \\ Julgamento: 13.4 .11}

DiREITO SANITÁRIO CONSUMERISTA. PLANOS DE SAÚdE. AUTORIZAÇÃO PARA PROCEDIMENTO CIRÚRGICO NEGADA. Trata-se de agravo contra decisão que negou seguimento a recurso extraordinário interposto de acórdão, cuja ementa segue transcrita, no que importa: "CONSUMIDOR. PLANOS DE SAÚDE. AUTORIZAÇÃO PARA PROCEDIMENTO CIRÚRGICO NEGADA. DANO MORAL CONFIGURADO. QUANTUM INDENIZATÓRIO MANTIDO. 1. Plenamente cabível indenização por danos morais decorrentes da negativa de autorização para procedimento cirúrgico. 2. Quantum indenizatório mantido, por ser proporcional e razoável. 
Sentença confirmada por seus próprios fundamentos. Recurso improvido" (fl. 88). No RE, fundado no art. 102, III, a, da Constituição, alegou-se ofensa, em suma, os arts. 5으. II, V, X, XXXV, XXXVI, LIV, LV e § $2^{\circ}$, e 93, IX, da mesma Carta. O agravo não merece acolhida. Isso porque, os dispositivos constitucionais apontados como violados não foram devidamente prequestionados. Assim, como tem consignado o Tribunal, por meio da Súmula 282, é inadmissível o recurso extraordinário se a questão constitucional suscitada não tiver sido apreciada no acórdão recorrido. Ademais, não opostos embargos declaratórios para suprir essa omissão, é inviável o recurso, a teor da Súmula 356 do STF. Nesse sentido: "AGRAVO REGIMENTAL EM AGRAVO DE INSTRUMENTO. AUSÊNCIA DE PREQUESTIONAMENTO DAS MATÉRIAS CONSTITUCIONAIS SUSCITADAS. INCIDÊNCIA DAS SÚMULAS 282 E 356 DO STF. 1. Os temas constitucionais suscitados no apelo extremo não foram objeto de análise prévia, e conclusiva, pela Instância Judicante de origem. Pelo que incidem as Súmulas 282 e 356 desta Corte. 2. Agravo regimental desprovido" (AI 770.103-AgR/RJ, Rel Min. Ayres Britto, Primeira Turma). Isso posto, nego seguimento ao recurso. Publique-se. Brasília, 13 de abril de 2011. Ministro RICARDO LEWANDOWSKI, Relator.

Supremo Tribunal Federal

Processo: ARE 638569/PA — PARÁ RECURSO EXTRAORDINÁRIO COM AGRAVO

Relator: Ricardo Lewandowski

Julgamento: 13.4.11

DIREITO SANITÁRIO PREVIDENCIÁRIO. APOSENTADORIA ESPECIAL. Trata-se de mandado de injunção contra alegada omissão na elaboração da norma regulamentadora prevista no art. 40, § 4, III, da Constituição Federal. A Advocacia-Geral da União manifestou-se pelo não conhecimento da impetração. É o breve relatório. Decido. Inicialmente, consigno que deixei de ouvir a Procuradoria-Geral da República, uma vez que, em inúmeros outros casos que versavam sobre a mesma questão constitucional, manifestou-se o Parquet pelo deferimento parcial do mandamus, em razão da ausência de regulamentação do art. 40, § 4․ III, da Carta Magna. Nesse sentido, cito, entre outros, os seguintes processos: Mandados de Injunção 928/DF, 895/ DF e 865/DF, todos de minha relatoria. Assento, também, que a via do mandado de injunção é adequada para dirimir a questão sob comento: saber qual a lei a ser aplicada a fim de assegurar, na espécie, o direito à aposentadoria especial, em razão do exercício de atividade exercida exclusivamente sob condições que prejudiquem a saúde ou a integridade física, prevista no $\S 4^{\circ}$, III, do art. 40 da Constituição Federal, verbis: "Art. 40 (...) $\S 4^{\circ}$ É vedada a adoção de requisitos e critérios diferenciados para a concessão de aposentadoria aos abrangidos pelo regime de que trata este artigo, ressalvados, nos termos definidos em leis complementares, os casos de servidores: (...) III - cujas atividades sejam exercidas sob condições 
especiais que prejudiquem a saúde ou a integridade física" (grifos meus). Com efeito, nos termos do art. 5ํ, LXXI, da Constituição Federal: "conceder-se-á mandado de injunção sempre que a falta de norma regulamentadora torne inviável o exercício dos direitos e liberdades constitucionais e das prerrogativas inerentes à nacionalidade, à soberania e à cidadania". Conforme assente na jurisprudência da Corte, não existe lei regulamentadora do direito à aposentadoria especial em razão de atividade exercida exclusivamente sob condições que prejudiquem a saúde ou a integridade física, prevista no $\S 4^{\circ}$ do art. 40 da Constituição Federal. Assim, afigura-se correto o remédio constitucional escolhido, pois não há, à falta de previsão legal, direito líquido e certo amparável por meio do mandado de segurança. Nessa linha, a jurisprudência do Supremo Tribunal Federal, após o julgamento dos Mandados de Injunção 721/DF e 758/DF, Rel. Min. Marco Aurélio, passou a adotar a tese que essa garantia constitucional destina-se à concretização, caso a caso, do direito constitucional não regulamentado, assentando, ainda, que com ele não se objetiva apenas declarar a omissão legislativa, dada a sua natureza nitidamente mandamental. Transcrevo a ementa do MI 758/DF citado: "MANDADO DE INJUNÇÃO - NATUREZA. Conforme disposto no inciso LXXI do art. 5 da Constituição Federal, conceder-se-á mandado de injunção quando necessário ao exercício dos direitos e liberdades constitucionais e das prerrogativas inerentes à nacionalidade, à soberania e à cidadania. Há ação mandamental e não simplesmente declaratória de omissão. A carga de declaração não é objeto da impetração, mas premissa de ordem a ser formalizada. MANDADO DE INJUNÇÃO DECISÃO - BALIZAS. Tratando-se de processo subjetivo, a decisão possui eficácia considerada a relação jurídica nele revelada. APOSENTADORIA TRABALHO EM CONDIÇỐES ESPECIAIS - PREJUÍZO À SAÚDE DO SERVIDOR - INEXISTÊNCIA DE LEI COMPLEMENTAR - ART. 40, § 4º, DA CONSTITUIÇÃO FEDERAL. Inexistente a disciplina específica da aposentadoria especial do servidor, impõe-se a adoção, via pronunciamento judicial, daquela própria aos trabalhadores em geral - art. 57, § 1ㅜㄹ da Lei n. 8.213/91". Referido entendimento foi reafirmado nos julgamentos dos Mandados de Injunção 795, 797, 809, 828, 841, 850, 857, 879, 905, 927, 938, 962, 998, 788, 796, 808, 815 e 825, conforme se observa da notícia publicada em 15/4/2009, no sítio eletrônico do STF, abaixo transcrita: "Nesta quarta-feira (15), o Supremo Tribunal Federal (STF) permitiu que pedidos de aposentadoria de servidores públicos que trabalham em situação de insalubridade e de periculosidade sejam concedidos de acordo com as regras do art. 57 da Lei n. 8.213/91, que regulamenta a aposentadoria especial de celetistas. Os pedidos devem ser analisados caso a caso e dependem de o interessado provar que cumpre os requisitos legais previstos para a concessão do benefício. A decisão seguiu precedente (MI 721) do Plenário que, em agosto de 2007, permitiu a aplicação da norma a uma servidora da área da saúde. Ela teve sua aposentadoria negada por falta de regulamentação do dispositivo constitucional que permite a aposentadoria 
especial no caso de trabalho insalubre e de atividades de risco. A regra está disposta no parágrafo $4^{\circ}$ do art. 40 da Constituição Federal, mas depende de regulamentação. Por isso, pedidos de aposentadoria feitos por servidores públicos acabam sendo rejeitados pela Administração. Para garantir a concessão do benefício, o Supremo está permitindo a aplicação da Lei $\mathrm{n}$. 8.213/91, que regulamenta a concessão de benefícios da Previdência Social. Ao todo, foram julgados 18 processos de servidores, todos mandados de injunção, instrumento jurídico apropriado para garantir o direito de alguém prejudicado diante da omissão legislativa na regulamentação de normas da Constituição. Nesta tarde, os ministros decretaram a omissão legislativa do presidente da República em propor lei que trate da matéria, que está sem regulamentação há mais de 10 anos. A Corte também determinou que os ministros poderão aplicar monocraticamente essa decisão aos processos que se encontram em seus gabinetes, sem necessidade de levar cada caso para o Plenário" (grifei). Dessa forma, a concessão de aposentadoria em razão do exercício de atividade exercida exclusivamente sob condições que prejudiquem a saúde ou a integridade física deve ser analisada com a aplicação do art. 57 da Lei n. 8.213/91, norma que dispõe sobre os Planos de Benefícios da Previdência Social, que se encontra assim redigido: "Art. 57. A aposentadoria especial será devida, uma vez cumprida a carência exigida nesta Lei, ao segurado que tiver trabalhado sujeito a condições especiais que prejudiquem a saúde ou a integridade física, durante 15 (quinze), 20 (vinte) ou 25 (vinte e cinco) anos, conforme dispuser a lei. § 1ㅇ A aposentadoria especial, observado o disposto no art. 33 desta Lei, consistirá numa renda mensal equivalente a $100 \%$ (cem por cento) do salário de benefício. $\S 20$ A data de início do benefício será fixada da mesma forma que a da aposentadoria por idade, conforme o disposto no art. 49. § 3ํㅗ A concessão da aposentadoria especial dependerá de comprovação pelo segurado, perante o Instituto Nacional do Seguro Social - INSS, do tempo de trabalho permanente, não ocasional nem intermitente, em condições especiais que prejudiquem a saúde ou a integridade física, durante o período mínimo fixado. $\S 4^{\circ}$ O segurado deverá comprovar, além do tempo de trabalho, exposição aos agentes nocivos químicos, físicos, biológicos ou associação de agentes prejudiciais à saúde ou à integridade física, pelo período equivalente ao exigido para a concessão do benefício. $\S 5^{\circ} \mathrm{O}$ tempo de trabalho exercido sob condições especiais que sejam ou venham a ser consideradas prejudiciais à saúde ou à integridade física será somado, após a respectiva conversão ao tempo de trabalho exercido em atividade comum, segundo critérios estabelecidos pelo Ministério da Previdência e Assistência Social, para efeito de concessão de qualquer benefício. $\S 600$ benefício previsto neste artigo será financiado com os recursos provenientes da contribuição de que trata o inciso II do art. 22 da Lei n. 8.212, de 24 de julho de 1991, cujas alíquotas serão acrescidas de doze, nove ou seis pontos percentuais, conforme a atividade exercida pelo segurado a serviço da empresa permita a concessão de aposentadoria especial após 
quinze, vinte ou vinte e cinco anos de contribuição, respectivamente. $\S 7^{\circ} \mathrm{O}$ acréscimo de que trata o parágrafo anterior incide exclusivamente sobre a remuneração do segurado sujeito às condições especiais referidas no caput. $\S 8^{\circ}$ Aplica-se o disposto no art. 46 ao segurado aposentado nos termos deste artigo que continuar no exercício de atividade ou operação que o sujeite aos agentes nocivos constantes da relação referida no art. 58 desta Lei". Ocorre, todavia, que a contagem de tempo, com todas as suas intercorrências, somente pode ser aferida, de forma concreta, pela Administração Pública, à luz dos dados constantes do prontuário do servidor, razão pela qual o pleito não pode ser provido, desde logo, de forma integral. Vale ressaltar, ademais, que, enquanto não editada a lei a que se refere o art. 40, § 4ํㅡㄴ III, da Constituição, o parâmetro a ser utilizado é apenas a Lei $n$. 8.213/1991, não podendo ocorrer combinação de regimes, conforme decidiu este Tribunal por ocasião do julgamento do MI 758-ED/DF, Rel. Min. Marco Aurélio, cujo acórdão foi assim ementado: "EMBARGOS DECLARATÓRIOS - PRESTAÇÃO JURISDICIONAL. Os embargos declaratórios visam ao aperfeiçoamento da prestação jurisdicional, devendo, por isso mesmo, merecer compreensão por parte do órgão julgador. APOSENTADORIA ESPECIAL - SERVIDOR PÚBLICO - TRABALHO EM AMBIENTE INSALUBRE - PARÂMETROS. Os parâmetros alusivos à aposentadoria especial, enquanto não editada a lei exigida pelo texto constitucional, são aqueles contidos na Lei n. 8.213/91, não cabendo mesclar sistemas para, com isso, cogitar-se de idade mínima”. Registro, ainda, que esse entendimento aplica-se a todos os servidores públicos, independentemente do ente da federação ao qual pertençam, conforme assentado por esta Corte no julgamento do RE 238.591-AgR/DF, Rel. Min. Ellen Gracie, que foi assim ementado: "CONSTITUCIONAL E ADMINISTRATIVO. APOSENTADORIA ESPECIAL. ATIVIDADE INSALUBRE. SERVIDORA DISTRITAL. JURISPRUDÊNCIA CONSOLIDADA: MANDADOS DE INJUNÇÃO 721/DF E 758/DF. 1. Eventual alteração de regime funcional da ora agravada, bem como o fato de ter sido servidora distrital, não impedem a aplicação da jurisprudência do Supremo Tribunal Federal (Mandados de Injunção 721/DF e 758/DF), ainda que considerado o disposto no art. 40, $\S 1^{\circ}$, da Constituição da República, o qual, por si só, também não elidiria a incidência dos citados precedentes. 2. Os julgados citados na decisão recorrida, porque proferidos pelo Plenário desta Corte, nos autos do MI 721/DF e do MI 758/DF, todos da relatoria do Min. Marco Aurélio, pub. DJE 30.11.2007 e 26.09.2008, respectivamente, traduzem a jurisprudência dominante do Supremo Tribunal Federal sobre a matéria aqui discutida, o que faz incidir o disposto no art. 557, caput, do CPC, não havendo falar que os efeitos daquelas decisões somente seriam inter pars. 3. Agravo regimental improvido". Isso posto, considerada a falta do diploma regulamentador a que se refere o art. 40, $4^{\circ}$, III, da Constituição Federal, concedo a ordem em parte para que o pleito de aposentadoria especial seja analisado pela autoridade administrativa, a quem compete a verificação do preenchimento ou não dos requisitos legais, em 
especial os do art. 57 da Lei n. 8.213/1991. Publique-se. Brasília, 12 de abril de 2011. Ministro RICARDO LEWANDOWSKI, Relator.

Supremo Tribunal Federal

Processo: MI 3769/DF - DISTRITO FEDERAL MANDADO DE INJUNÇÃO

Relator: Ricardo Lewandowski

Julgamento: 12.4.11

DIREITO SANITÁRIO PREVIDENCIÁRIO. APOSENTADORIA ESPECIAL. De início, defiro o pedido de justiça gratuita (Lei n. 1.060/50). Passo, ora, à análise da causa. Trata-se de mandado de injunção impetrado contra suposta omissão na edição da lei complementar prevista no art. 40, § 4º, da Constituição da República. O impetrante afirma ser servidor público e ter desempenhado suas funções, de forma permanente, em contato com agentes nocivos à saúde e à integridade física. Nesse sentido, pleiteia a contagem diferenciada do tempo de serviço prestado em condições insalubres e, sucessivamente, a aplicação, ao caso, do disposto na legislação que regulamenta a aposentadoria especial dos trabalhadores do setor privado, a exemplo do art. 57 da Lei $n$. $8.213 / 1991$. Preliminarmente, verifico ser incabível o writ no que diz respeito ao primeiro pedido formulado pelo impetrante. Diferentemente do que afirmado na inicial, a Constituição não dispõe sobre o suposto direito à contagem diferenciada do tempo de serviço prestado em condições prejudiciais à saúde ou à integridade física, tampouco exige a sua regulamentação. O inciso III do $\S 4^{\circ}$ do art. 40 da Constituição assegura tão somente o direito à aposentadoria especial para os servidores que tenham exercido suas atividades em tais condições. Portanto, não conheço do presente mandado de injunção no que se refere ao pedido de contagem diferenciada do tempo de serviço exercido em condições insalubres. Passo a analisar o segundo pedido formulado na inicial. Conforme afirmado por diversas vezes na jurisprudência deste Tribunal, verifico que não há lei regulamentadora do direito dos servidores públicos à aposentadoria especial em razão de atividade exercida nas condições do $\S 4^{\circ}$ do art. 40 da Constituição. Nesse sentido, esta Corte, no julgamento do MI 721, de relatoria do Ministro Marco Aurélio, deferiu parcialmente o pedido para determinar a aplicação do art. 57, § 1ำ da Lei n. 8.213/1991, de modo a viabilizar a análise do requerimento de aposentadoria especial formulado por servidora pública que realizara, por mais de 25 anos, atividade em ambiente insalubre. Eis o teor da ementa desse julgado: "MANDADO DE INJUNÇÃO - NATUREZA. Conforme disposto no inciso LXXI do art. $5^{\circ}$ da Constituição Federal, conceder-se-á mandado de injunção quando necessário ao exercício dos direitos e liberdades constitucionais e das prerrogativas inerentes à nacionalidade, à soberania e à cidadania. Há ação mandamental e não simplesmente declaratória de omissão. A carga de declaração não é objeto da impetração, mas premissa da ordem a ser formalizada. MANDADO DE INJUNÇÃO DECISÃO - BALIZAS. Tratando-se de processo subjetivo, a decisão possui 
eficácia considerada a relação jurídica nele revelada. APOSENTADORIA TRABALHO EM CONDIÇÕES ESPECIAIS - PREJUÍZO À SAÚDE DO SERVIDOR - INEXISTÊNCIA DE LEI COMPLEMENTAR — ART. 40, § 4은 DA CONSTITUIÇÃO FEDERAL. Inexistente a disciplina específica da aposentadoria especial do servidor, impõe-se a adoção, via pronunciamento judicial, daquela própria aos trabalhadores em geral - art. 57, § 1, da Lei $n$. 8.213/91." (MI 721, Rel. Min. Marco Aurélio, DJ 30.11.2007). Essa orientação foi reiterada no julgamento do MI 795, nos seguintes termos: "MANDADO DE INJUNÇÃO. APOSENTADORIA ESPECIAL DO SERVIDOR PÚBLICO. ART. $40, \S 4^{\circ}$, DA CONSTITUIÇÃO DA REPÚBLICA. AUSÊNCIA DE LEI COMPLEMENTAR A DISCIPLINAR A MATÉRIA. NECESSIDADE DE INTEGRAÇÃO LEGISLATIVA. 1. Servidor público. Investigador da polícia civil do Estado de São Paulo. Alegado exercício de atividade sob condições de periculosidade e insalubridade. 2. Reconhecida a omissão legislativa em razão da ausência de lei complementar a definir as condições para o implemento da aposentadoria especial. 3. Mandado de injunção conhecido e concedido para comunicar a mora à autoridade competente e determinar a aplicação, no que couber, do art. 57 da Lei n. 8.213/91." (MI 795, Rel. Min. Cármen Lúcia, DJe 94, divulgado em 21.5.2009). Nessa ocasião, o Plenário, em questão de ordem suscitada pelo Ministro Joaquim Barbosa, autorizou aos Ministros que decidam monocrática e definitivamente os casos idênticos aos MI 721, 758 e 795. Nesse ponto, citem-se os seguintes precedentes: MI 788, Rel. Min. Ayres Britto, DJ 8.5.2009; MI 925, Rel. Min. Cezar Peluso, DJ 23.6.2009; MI 1.328, Rel. Min. Ricardo Lewandowski, DJ 1‥2.2010; MI 1.527, Rel. Min. Eros Grau, DJ 5.3.2010; MI 2.120, Rel. Min. Joaquim Barbosa, DJ 24.3.2010; MI 1.785, Rel. Min. Ellen Gracie, DJ 29.3.2010; MI 2.701, Rel. Min. Celso de Mello, DJ 24.5.2010; MI 1.493, Rel. Min. Cármen Lúcia, DJ 4.6.2010. Em todas as decisões, deferiu-se parcialmente a ordem para determinar a análise do caso dos impetrantes à luz do disposto na disciplina conferida aos trabalhadores em geral. Referida disciplina consiste, entre outras normas, nos artigos 57, 58 e 65 da Lei n. 8.213/1991 e no Anexo IV do Regulamento da Previdência Social (Decreto 3.048/1999). É necessário esclarecer que a decisão proferida por esta Corte nos mandados de injunção impetrados contra omissão na regulamentação do art. 40, § 4ํㅡㄹ da Constituição não determina a concessão da aposentadoria especial ao impetrante. A decisão do STF determina apenas que a autoridade administrativa analise o caso do impetrante à luz da disciplina da aposentadoria especial dos trabalhadores do setor privado. Nesse sentido, para ter o direito à aposentadoria especial, o servidor deve comprovar à Administração ter trabalhado, ininterruptamente, em contato com agentes nocivos à saúde ou à integridade física durante 15, 20 ou 25 anos (Parágrafos $3^{\circ}$ e $4^{\circ}$ do art. 57 da Lei n. 8.213/1991). A relação de agentes considerados nocivos, bem como o tempo de exposição necessário para ensejar a concessão da aposentadoria especial, encontra-se no Anexo IV do Regulamento da Previdência Social (Decreto 3.048/1999), 
periodicamente atualizado. Assim, uma vez concedida a ordem por esta Corte, caberá à autoridade administrativa a verificação do atendimento, ou não, pelo impetrante, dos requisitos necessários à concessão da aposentadoria especial (tempo de serviço exercido nas condições prejudiciais, apresentação de laudo pericial etc.). Da leitura da petição inicial e dos documentos acostados aos autos, verifico que o presente caso configura hipótese análoga àquelas já decididas por esta Corte. Ante o exposto, conheço parcialmente o mandado de injunção e, nessa parte, concedo parcialmente a ordem, tão somente para determinar à autoridade administrativa que analise o requerimento de aposentadoria especial do impetrante à luz da disciplina conferida aos trabalhadores em geral, de modo a verificar se o servidor comprova - inclusive por meio de laudo técnico circunstanciado de condições ambientais das atividades exercidas - ter exercido suas atividades em contato com os agentes nocivos listados no Anexo IV do Regulamento da Previdência Social (Decreto n. 3.048/1999) de forma ininterrupta durante o tempo ali determinado. Publique-se. Comunique-se às autoridades impetradas, ao Município de Porto Alegre e ao Departamento Municipal de Previdência dos Servidores do Município de Porto Alegre. Brasília, 12 de abril de 2011. Ministro GILMAR M ENDES, Relator.

Supremo Tribunal Federal

Processo: MI 3295/DF — DISTRITO FEDERAL MANDADO DE INJUNÇÃO

Relator: Gilmar Mendes

Julgamento: 12.4.11

DIREITO PÚBLICO DA SAÚDE. FEDERALISMO. SUS. Andreia Pichorim interpõe recurso extraordinário, com fundamento na alínea "a" do permissivo constitucional, contra acórdão da $2^{\text {a }}$ Turma Recursal do Tribunal de Justiça do Estado do Paraná, que declarou "a ilegitimidade passiva da União Federal, e considerando a impossibilidade da remessa do processo ao Juízo competente, julgá-lo extinto, sem julgamento do mérito, por força do art. 267, VI, do CPC" (fl. 138). Alega a recorrente que "a responsabilidade solidária da União Federal no provimento da saúde aos cidadãos brasileiros está estampada nos artigos 196, caput e 198, caput e respectivo $\S 1^{\circ}$, não podendo ser suprimida por normas infraconstitucionais" (fl. 147). Contra-arrazoado (fls. 181 a 193), o recurso extraordinário (fls. 140 a 150) foi admitido (fls. 194 a 197). Decido. Anote-se, inicialmente, que o recurso extraordinário foi interposto contra acórdão publicado após 3/5/07, quando já era plenamente exigível a demonstração da repercussão geral da matéria constitucional objeto do recurso, conforme decidido na Questão de Ordem no Agravo de Instrumento n. 664.567/RS, Tribunal Pleno, Relator o Ministro Sepúlveda Pertence, DJ de 6/9/07. Todavia, apesar da petição recursal haver trazido a preliminar sobre o tema, não é de se proceder ao exame de sua existência, uma vez que, nos termos do art. 323 do Regimento Interno do Supremo Tribunal Federal, com a redação introduzida pela Emenda Regimental n. 21/ 
07, primeira parte, o procedimento acerca da existência da repercussão geral somente ocorrerá "quando não for o caso de inadmissibilidade do recurso por outra razão". Merece prosperar a irresignação. O Tribunal de origem decidiu a controvérsia sobre a legitimidade passiva da União na obrigação de fornecer medicamentos de forma contrária a jurisprudência desta Corte. Nesse sentido, anote-se o seguinte julgado do Plenário desta Corte: "Suspensão de Segurança. Agravo Regimental. Saúde pública. Direitos fundamentais sociais. Art. 196 da Constituição. Audiência Pública. Sistema Único de Saúde - SUS. Políticas públicas. Judicialização do direito à saúde. Separação de poderes. Parâmetros para solução judicial dos casos concretos que envolvem direito à saúde. Responsabilidade solidária dos entes da Federação em matéria de saúde. Fornecimento de medicamento: Zavesca (miglustat). Fármaco registrado na ANVISA. Não comprovação de grave lesão à ordem, à economia, à saúde e à segurança públicas. Possibilidade de ocorrência de dano inverso. Agravo regimental a que se nega provimento" (SS n. 175/CE-AgR, Segunda Turma, Relator o Ministro Gilmar Mendes, DJ de 30/4/10)" (STA n. 175/CE-AgR, Relator o Ministro Gilmar Mendes, DJ de 30/4/10). Aplicando essa orientação, a Primeira Turma deste Supremo Tribunal Federal, no julgamento do RE n. 808.059/RS-AgR, Relator o Ministro Ricardo Lewandowski, publicado no DJe de 1\%/2/11, "fixou entendimento no sentido de que a obrigação dos entes da federação no que tange ao dever fundamental de prestação de saúde é solidária". Desse modo, a responsabilidade dos entes federados é solidária e subsidiária no dever fundamental de prestação de saúde. Nesse sentido, as recentes decisões monocráticas: Al n. 817.241/RS, Relator o Ministro Joaquim Barbosa, DJe de 14/10/10; RE n. 839.594/MG, Relatora a Ministra Cármen Lúcia, DJe de 3/3/ 11, e AI n. 732.582/SP, Relatora a Ministra Ellen Gracie, DJe de 17/3/11. Ante o exposto, nos termos do art. 557, § 1-A, do Código de Processo Civil, conheço do recurso extraordinário e lhe dou provimento para reconhecer a legitimidade passiva da União e determinar o retorno dos autos à origem para regular prosseguimento do feito, como de direito. Publique-se. Brasília, 12 de abril de 2011. Ministro DIAS TOFFOLI, Relator.

Supremo Tribunal Federal

Processo: RE 587084/PR — PARANÁ RECURSO EXTRAORDINÁRIO Relator: Dias Toffoli

Julgamento: 12.4.11

MEIOS DE CONTROLE EM DIREITO SANITÁRIO. VIGILÂNCIA SANITÁRIA. FEDERALISMO. 1. Trata-se de recursos extraordinários interpostos pelo Município de Erechim e pelo Ministério Público do Rio Grande do Sul, contra acórdão o qual determinou ao Município de Erechim - RS que se abstenha de interditar poço artesiano clandestino, escavado em área urbana, em virtude da existência de prova de potabilidade da água. 2. Em seu RE, o Ministério Público Estadual alega violação aos arts. 23, VI e XI, e 225, caput, da Constituição Federal, sustentando, em síntese, que o município tem 
competência material para exercer o poder de polícia acerca da exploração de poços artesianos, porquanto os recursos hídricos são bens de natureza ambiental (fls. 255-264). O Município de Erechim alega violação ao art. 23, II, VI e XI, da Constituição Federal, sustentando, em síntese, competir à vigilância sanitária municipal fiscalizar o uso e consumo de água em desacordo com a legislação (fls. 248-253). 3. Admitidos os recursos na origem (fls. 266-267v.), subiram os autos. 4. O Ministério Público Federal manifestou-se pelo provimento dos recursos (fls. 279-282). 5. Os recursos não merecem prosperar. Preliminarmente, verifico que o art. 225, caput, da Constituição Federal, apontado como violado no recurso do Ministério Público Estadual não se encontra prequestionado, porque não abordado pelo acórdão recorrido, nem suscitado nos embargos de declaração opostos para satisfazer o requisito do prequestionamento. Incidem, na espécie, as Súmulas STF 282 e 356. 6. Ademais, verifico que o Tribunal de origem decidiu a controvérsia com fundamento no conjunto fático-probatório dos autos e na legislação infraconstitucional que disciplina a matéria. Veja-se: "No caso dos autos, entretanto, diante da existência de prova da potabilidade da água oriunda do poço artesiano, conforme se comprova com as análises periodicamente realizadas pela impetrante e juntadas às fls. 17-20, o Município não mais se mostra competente para proceder à devida fiscalização ou mesmo proceder no lacramento do poço artesiano, porquanto sua competência está estritamente relacionada com o problema relativo à saúde pública, hipótese descartada na presente situação. É que neste caso houve o deslocamento da controvérsia a respeito da possibilidade, ou não, do uso do poço artesiano em zona servida por rede pública de água, para fora do âmbito da saúde pública. (...) E ao que se constata do julgamento do auto de infração de fls. 16, a impetrante fora autuada por infração aos artigos 81 ao 98 do Decreto Estadual n. 23.430/74, ou seja, por estar utilizando água de fonte alternativa de abastecimento em zona servida por rede pública e não por qualquer questão relacionada à saúde pública, como, por exemplo, por impotabilidade da água (fl. 211). Assim, diante da preocupação com a finitude deste bem essencial à vida, é que foi instituída a Política Nacional de Recursos Hídricos e criado o Sistema Nacional de Gerenciamento de Recursos Hídricos, regulamentando o inciso XIX do art. 21 da Constituição Federal, Lei n. 9.433/ 97, mais conhecida como Lei das Águas, cujos fundamentos e objetivos são: 'Art. 1ํ A Política Nacional de Recursos Hídricos baseia-se nos seguintes fundamentos: I - a água é um bem de domínio público; II - a água é um recurso natural limitado, dotado de valor econômico; III - em situações de escassez, o uso prioritário dos recursos hídricos é o consumo humano e a dessedentação de animais; IV — a gestão dos recursos hídricos deve sempre proporcionar o uso múltiplo das águas; $V$ - a bacia hidrográfica é a unidade territorial para implementação da Política Nacional de Recursos Hídricos e atuação do Sistema Nacional de Gerenciamento de Recursos Hídricos; VI a gestão dos recursos hídricos deve ser descentralizada e contar com a 
participação do Poder Público, dos usuários e das comunidades. CAPÍTULO II - DOS OBJETIVOS. Art. 2o São objetivos da Política Nacional de Recursos Hídricos: I - assegurar à atual e às futuras gerações a necessária disponibilidade de água, em padrões de qualidade adequados aos respectivos usos; II - a utilização racional e integrada dos recursos hídricos, incluindo o transporte aquaviário, com vistas ao desenvolvimento sustentável; III - a prevenção e a defesa contra eventos hidrológicos críticos de origem natural ou decorrentes do uso inadequado dos recursos naturais. sem grifos no original'” (fls. 210-211). Assim, para o exame das violações alegadas, seria necessária a análise de fatos e provas (Súmula STF 279) e de legislação infraconstitucional e local (Lei n. 9.433/97 e Decreto Estadual 23.430/74), hipóteses inviáveis em sede extraordinária. 7. Ademais, frise-se que contra 0 acórdão recorrido os recorrentes interpuseram, concomitantemente, recurso especial (REsp 927.788/RS, rel. Min. José Delgado, trânsito em julgado em 20.6.2007) ao qual fora negado seguimento por inexistir ofensa à legislação federal e pela necessidade de reexame da legislação local (Súmula STF 280). Permanece válido, portanto, o fundamento infraconstitucional suficiente para a manutenção do acórdão recorrido, referente à aplicação da Lei n. 9.433/97. Incide, pois, a Súmula STF 283. Nesse sentido foi o decidido no RE 592.690/RS, rel. Min. Cármen Lúcia DJe 09.9.2009, caso semelhante ao dos presentes autos, em que também aparece como recorrente o Município de Erechim, cuja ementa transcrevo: "RECURSO EXTRAORDINÁRIO. UTILIZAÇÃO DE ÁGUA PROVENIENTE DE FONTE ALTERNATIVA. JULGADO RECORRIDO COM FUNDAMENTO INFRACONSTITUCIONAL AUTÔNOMO: INCIDÊNCIA DA SÚMULA 283 DO SUPREMO TRIBUNAL FEDERAL. REPERCUSSÃO GERAL DA QUESTÃO CONSTITUCIONAL: DESNECESSIDADE. INTIMAÇÃO DO ACÓRDÃO RECORRIDO ANTERIOR A 3.5.2007. RECURSO AO QUAL SE NEGA SEGUIMENTO".8. Ante o exposto, nego seguimento aos recursos extraordinários (art. 557, caput, do CPC). Publique-se. Brasília, 06 de abril de 2011. Ministra ELLEN GRACIE, Relatora.

\section{Supremo Tribunal Federal \\ Processo: RE 553722/RS - RIO GRANDE DO SUL RECURSO EXTRAORDINÁRIO \\ Relatora: Ellen Gracie \\ Julgamento: 6.4.11}

DIREITO PÚBLICO SANITÁRIO. ADMINISTRATIVO. ESTADO DE NECESSIDADE. TRÂNSITO. 1. Tem-se hipótese em que o veículo do recorrido foi autuado por duas infrações de trânsito, consistentes ambas em excesso de velocidade. $O$ condutor recorrido não nega o cometimento das infrações, mas discute a aplicação das penalidades, sustentando que cometeu as irregularidades em estado de necessidade (pois levava a filha ao hospital 
em razão de queimaduras extremamente lesivas à saúde da criança). 2. A parte recorrente aduz que a disciplina penal do estado de necessidade não é suficiente para afastar a incidência das penalidades, devendo prevalecer o interesse público geral, consubstanciado na proteção à vida e na garantia de trânsito em condições seguras. Alega-se, ainda, com base no art. 29, inc. VII, alíneas "a" a "d", do CTB, que mesmo os veículos destinados a socorro devem obedecer as regras de trânsito, razão por que os particulares não podem deixar de a elas se submeterem também. 3. O estado de necessidade não é instituto inerente apenas ao Direito Penal; ao contrário, tem-se aí conceito ligado a todo o Direito Sancionador - inclusive nos ramos cível e administrativo. 4. A figura do estado de necessidade liga-se à ideia de que não pode existir atentado ao Direito, ao justo, na conduta praticada a fim de salvaguardar bem jurídico de maior relevância que o bem jurídico maculado. A lógica é evidente: o ordenamento jurídico não pode deslegitimar conduta que é benéfica a bem jurídico a que ele próprio confere valor diferenciado (para mais). 5. A legitimidade da conduta, neste caso, deve ser compreendida de forma abrangente, englobando tanto o aspecto penal, como os aspectos cível e administrativo. 6. Tanto é assim que o Código Civil em vigor, na esteira do que já dispunha o Código Civil revogado, dispõe serem lícitos os atos praticados em perigo iminente, desde que obedecida a proporcionalidade (em seus três testes: adequação, necessidade e proporcionalidade em sentido estrito). 7. Frise-se: apesar de a sistemática estabelecida pelo art. 188, inc. II e p. ún., do novo Código Civil não afastar o dever de reparação quando a conduta for praticada em estado de necessidade, ainda assim é caso literal de ato lícito (observados os contornos do p. único do dispositivo). 8. Na esfera administrativa, em razão da inexistência de codificação, não há dispositivo expresso sobre o instituto. Nada obstante, a construção de precedentes dos órgãos julgadores da Administração Pública e dos órgãos judiciais sempre foi no sentido do pleno reconhecimento e da real efetividade do estado de necessidade na seara administrativa. 9. Neste sentido, por exemplo, não custa trazer à baila os casos de ação de improbidade administrativa ajuizadas em face de administradores que, após realizarem o recolhimento das contribuições, não procedem ao devido repasse à Previdência em razão da necessidade de alocação das quantias em prol do interesse público. 10. Em tais hipóteses, esta Corte Superior, em reiterados precedentes, vem afastando a caracterização da improbidade administrativa por considerar configurado o estado de necessidade - da mesma forma como ocorre em relação aos arts. $2^{\circ}$, inc. I, da Lei n. 8.137/90 e 168-A do Código Penal - embora o estado de necessidade não disponha de previsão expressa na legislação administrativa. 11. Mais do que isto, conforme consta do acórdão recorrido, existe, no âmbito do Detran/DF (recorrente), entendimento segundo o qual, "nos casos de cometimento de infrações de trânsito em estado de necessidade, notadamente para atendimentos de urgências médicas, [deve ser] apresentada a Guia de Atendimento de Emergência (GAE)". 12. Assim sendo, o próprio recorrente reconhece que o estado de 
necessidade é suficiente para excluir os efeitos das infrações de trânsito apuradas, mas condiciona o reconhecimento da excludente à apresentação da GAE - o que, por certo, viola o direito dos administrados de provarem, por quaisquer meios legítimos, a ocorrência do estado de necessidade, dada a atipicidade dos meios probatórios. Em resumo: o Detran/DF já possui orientação administrativa pela invocabilidade do estado de necessidade como causa excludente das infrações de trânsito, havendo apenas discussão quanto aos meios de prova. 13. Não custa relembrar também os exemplos das grandes metrópoles, que, por conta da violência extrema, liberaram de controle por "pardais" alguns semáforos a partir de determinados horários, a fim justamente de impedir o perigo à vida dos cidadãos - medida preventiva a perigos eventuais. 14. Há ainda o argumento referente ao princípio da proporcionalidade. Basta que se proceda ao raciocínio seguinte: apenas uma conduta foi realizada, ou seja, direção de veículo automotor a $83 \mathrm{~km} / \mathrm{h}$ e $121 \mathrm{~km} / \mathrm{h}$, em vias cujas velocidades máximas são, respectivamente, $60 \mathrm{~km} / \mathrm{h}$ e $70 \mathrm{~km} / \mathrm{h}$. Suponha-se que, desta conduta, tenha havido dois resultados: infração administrativa à legislação de trânsito (excesso de velocidade, como na espécie) - que, consequentemente, reclamaria sanção administrativa e infração penal (e. g., lesão corporal culposa) - sancionável, em tese, por aplicação de reprimenda penal. 15. Seria no mínimo, desarrazoado - a não dizer injusto - , admitir-se que o estado de necessidade se prestaria a excluir uma infração penal relativa à proteção do bem jurídico integridade física e, ao mesmo tempo, ser inservível para excluir uma infração administrativa, que protege abstratamente a segurança pública, em razão de uma conduta singular, realizada em tempo, modo e condições únicos. 16. "Exige-se coerência e unidade de critérios, com obediência à segurança jurídica, de parte do Estado, quando pretende selecionar comportamentos proibidos e castigá-los. [...] A relação punitiva, na qual o Estado aparece com seus poderes e o indivíduo, a pessoa, não importa se física ou jurídica, com seus direitos em jogo, há de ser proporcional. [...] Um dos elementos que permite ao Judiciário o exame da proporcionalidade é, sem dúvida, a constatação de um mínimo de coerência legislativa nos atos sancionadores. Tal exigência decorre, também, da unidade do sistema jurídico e dos princípios da igualdade e da segurança jurídica. O legislador não é uma entidade mágica, dotada de ilimitados poderes, que não deve prestar contas aos demais poderes do Estado" (Direito administrativo sancionador, 2005, p. 228/231). 17. Apesar de a lição doutrinária se referir aos tipos sancionadores em si, nada impede a sua aplicação às questões relativas às excludentes gerais de ilicitude, porque a necessidade de observância de coerência decorre da inserção das normas, de quaisquer esferas, em um sistema - no caso, um sistema jurídico. 18. Recurso especial não provido. Acórdão. Vistos, relatados e discutidos esses autos em que são partes as acima indicadas, acordam os Ministros da SEGUNDA TURMA do Superior Tribunal de Justiça, na conformidade dos votos e das notas taquigráficas, o seguinte resultado de julgamento: "A Turma, por unanimidade, negou provimento ao recurso, nos 
termos do voto do Sr. Ministro Relator, sem destaque." Os Srs. Ministros Cesar Asfor Rocha, Castro Meira, Humberto Martins (Presidente) e Herman Benjamin votaram com o Sr. Ministro Relator.

Superior Tribunal de Justiça

Processo: REsp 1123876/DF RECURSO ESPECIAL 2009/0028809-8

Relator: Ministro Mauro Campbell Marques

Órgão Julgador: T2 — SEGUNDA TURMA

Data do Julgamento: 5.4.11

ÉTICA SANITÁRIA. DIREITO CIVIL DA SAÚDE. DANOS MORAIS E MATERIAIS. DIREITO À INTIMIDADE. I - O direito à intimidade, não é absoluto, aliás, como todo e qualquer direito individual. Na verdade, é de se admitir, excepcionalmente, a tangibilidade ao direito à intimidade, em hipóteses em que esta se revele necessária à preservação de um direito maior, seja sob o prisma individual, seja sob o enfoque do interesse público. Tal exame, é certo, não prescinde, em hipótese alguma, da adoção do princípio da dignidade da pessoa humana, como princípio basilar e norteador do Estado Democrático de Direito, e da razoabilidade, como critério axiológico; II — Sob o prisma individual, o direito de o indivíduo não saber que é portador do vírus HIV (caso se entenda que este seja um direito seu, decorrente da sua intimidade), sucumbe, é suplantado por um direito maior, qual seja, o direito à vida, o direito à vida com mais saúde, o direito à vida mais longeva e saudável; III - Mesmo que o indivíduo não tenha interesse ou não queira ter conhecimento sobre a enfermidade que lhe acomete (seja qual for a razão), a informação correta e sigilosa sobre seu estado de saúde dada pelo Hospital ou Laboratório, ainda que de forma involuntária, tal como ocorrera na hipótese dos autos, não tem o condão de afrontar sua intimidade, na medida em que Ihe proporciona a proteção a um direito maior; IV - Não se afigura permitido, tão pouco razoável que o indivíduo, com o desiderato inequívoco de resguardar sua saúde, após recorrer ao seu médico, que lhe determinou a realização de uma série de exames, vir a juízo aduzir justamente que tinha o direito de não saber que é portador de determinada doença, ainda que o conhecimento desta tenha se dado de forma involuntária. Tal proceder aproxima-se, em muito, da defesa em juízo da própria torpeza, não merecendo, por isso, guarida do Poder Judiciário; V - No caso dos autos, o exame efetuado pelo Hospital não contém equívoco, o que permite concluir que o abalo psíquico suportado pelo ora recorrente não decorre da conduta do Hospital, mas sim do fato de o recorrente ser portador do vírus HIV, no que o Hospital recorrido, é certo, não possui qualquer responsabilidade; VI — Sob o enfoque do interesse público, assinala-se que a opção de o paciente se submeter ou não a um tratamento de combate ao vírus HIV, que, ressalte-se, somente se tornou possível e, certamente, mais eficaz graças ao conhecimento da doença, dado por ato involuntário do Hospital, é de seu exclusivo arbítrio. Entretanto, o comportamento destinado a omitir-se sobre o conhecimento da doença, que, em última análise, gera condutas igualmente 
omissivas quanto à prevenção e disseminação do vírus HIV, vai de encontro aos anseios sociais; VII - Num momento em que o Poder Público, por meio de exaustivas campanhas de saúde, incentiva a feitura do exame anti HIV como uma das principais formas de prevenção e controle da disseminação do vírus HIV, tem-se que o comando emanado desta augusta Corte, de repercussão e abrangência nacional, no sentido de que o cidadão teria o direito subjetivo de não saber que é soropositivo, configuraria indevida sobreposição de um direito individual (que, em si não se sustenta, tal como demonstrado) sobre o interesse público, o que, data maxima venia, não se afigura escorreito; VII - Recurso Especial improvido. Acórdão. Vistos, relatados e discutidos os autos em que são partes as acima indicadas, acordam os Ministros da TERCEIRA TURMA do Superior Tribunal de Justiça, na conformidade dos votos e das notas taquigráficas a seguir, prosseguindo no julgamento, após o voto-vista do Sr. Ministro Sidnei Beneti, a Turma, por maioria, negou provimento ao recurso especial. Vencida a Sra. Ministra Relatora Nancy Andrighi. Votaram com o Sr. Ministro Massami Uyeda os Srs. Ministros Sidnei Beneti, Paulo de Tarso Sanseverino e Vasco Della Giustina (Desembargador convocado do TJ/RS). Lavrará o acórdão o Sr. Ministro Massami Uyeda.

Superior Tribunal de Justiça

Processo: REsp 1195995/SP - RECURSO ESPECIAL N. 2010/ 0098186-7

Relatora: Nancy Andrighi

Relator p/ Acórdão: Massami Uyeda

Órgão Julgador: T3 - TERCEIRA TURMA

Data do Julgamento: 22.3.11

DIREITO SANITÁRIO DO TRABALHO. DURAÇÃO DA JORNADA DE TRABALHO. EXERCÍCIO DE ATIVIDADES PREJU̧DICIAIS À SAÚDE. 1. O Decreto 4345/2005 não extrapola os limites da lei ao fixar a carga horária de 40 horas semanais para os servidores públicos, previsão esta já existente na Lei n. 13.666/2002 que, no entanto, poderá ser alterada desde que haja perícia comprovando o exercício de atividades prejudiciais à saúde, sendo certo, ainda, que a fixação da jornada de trabalho é tema sujeito aos critérios de oportunidade e conveniência do Poder Público. 2. A legislação federal estabeleceu como jornada de trabalho para os técnicos de radiologia 24 horas semanais, assim como o Decreto estadual, tendo em conta o fato de ser uma atividade prejudicial à saúde. Contudo, isso não significa que o servidor que exerce essa função não pode, nas 16 horas restantes para complementar a jornada de 40 horas semanais, desenvolver tarefas correlatas. Desse modo, não há que se falar em desvio de função. 3. Consoante a jurisprudência deste Superior Tribunal de Justiça, é vedada, no julgamento de recurso ordinário em mandado de segurança, a apreciação de matéria não abordada pelo Tribunal de origem, sob pena de supressão de instância. 4. Recurso ordinário conhecido parcialmente e improvido. Acórdão. Vistos, relatados e discutidos os autos em que são partes as acima indicadas, 
acordam os Ministros da Sexta Turma do Superior Tribunal de Justiça: "A Turma, por unanimidade, conheceu em parte do recurso em mandado de segurança e, nessa parte, negou-Ihe provimento, nos termos do voto da Sra. Ministra Relatora." Os Srs. Ministros Og Fernandes, Celso Limongi (Desembargador convocado do TJ/SP) e Haroldo Rodrigues (Desembargador convocado do TJ/CE) votaram com a Sra. Ministra Relatora. Presidiu o julgamento a Sra. Ministra Maria Thereza de Assis Moura.

Superior Tribunal de Justiça

Processo: RMS 23475/PR RECURSO ORDINÁRIO EM MANDADO DE SEGURANÇA 2007/0003733-5

Relatora: Maria Thereza de Assis Moura

Órgão Julgador: T6 — SEXTA TURMA

Data do Julgamento: 17.3.11

DIREITO SANITÁRIO CONSUMERISTA. DIREITO CIVIL DA SAÚDE. CONTRATO DE ADMINISTRAÇÃO DE PLANOS DE SEGURO-SAÚDE. I — Atendimento, mesmo após a extinção do contrato de administração de planos de seguro-saúde pactuado entre as partes, dos segurados da seguradora administrada na rede médico-hospitalar disponibilizada pela administradora. II - Suspensão, porém, pela seguradora administrada, do ressarcimento devido à administradora, que continuou a ter os atendimentos dos segurados daquela cobrados pela rede médico-hospitalar. III - Reconhecimento, pelo Tribunal de origem, do direito da administradora ser ressarcida, com a imposição de multa contratual de $10 \%$ à administrada, pelos atendimentos prestados posteriormente ao rompimento do contrato. IV - Rejeição das preliminares da recorrida de intempestividade do recurso especial e de não preenchimento dos requisitos do art. 541 do CPC. V - Inexiste violação ao art. 535 do CPC se o acórdão se manifesta a respeito das questões reputadas como não examinadas ou se a ausência de manifestação não configura omissão relevante para a solução da controvérsia. Precedentes. VI — Inviável, em razão do óbice da Súmula 07 deste Superior Tribunal de Justiça, o conhecimento das alegações de violação aos arts. 166, II, do CC; 389, 396, 407 e 408 do CC; e 422 do CC. VII - Embora, ao firmar o seu entendimento sobre a tese da recorrente de que o contrato teria sido resolvido por inadimplemento da recorrida, não tenha o Tribunal de origem observado a redação do art. 474 do CC, a aferição de quem causou a extinção do contrato não possui relevância, pois controvertidas apenas as questões do ressarcimento e da multa. VIII - Possibilidade de redistribuição, no caso concreto, dos honorários advocatícios, devendo ambas as partes arcar com a mesma quantia, devidamente compensada. IX - RECURSO ESPECIAL CONHECIDO EM PARTE E, NESTA, PROVIDO APENAS PARA REDISTRIBUIR OS HONORÁRIOS ADVOCATÍCIOS. Acórdão. Vistos, relatados e discutidos os autos em que são partes as acima indicadas, acordam os Ministros da Terceira Turma do Superior Tribunal de Justiça, por unanimidade, conhecer em parte do recurso especial e, nessa parte, dar-lhe 
provimento, nos termos do voto do(a) Sr(a). Ministro(a) Relator(a). Os Srs. Ministros Vasco Della Giustina (Desembargador convocado do TJ/RS), Nancy Andrighi e Massami Uyeda votaram com o Sr. Ministro Relator. Ausente, ocasionalmente, o Sr. Ministro Sidnei Beneti. Dr(a). LUÍS FELIPE FREIRE LISBÔA, pela parte RECORRENTE: GENERALI DO BRASIL COMPANHIA NACIONAL DE SEGUROS Dr(a). ALYSSON SOUSA MOURÃO, pela parte RECORRIDA: ASSOCIAÇÃO SULAMERICANA DE ASSISTÊNCIA MÉDICA - SULAMED

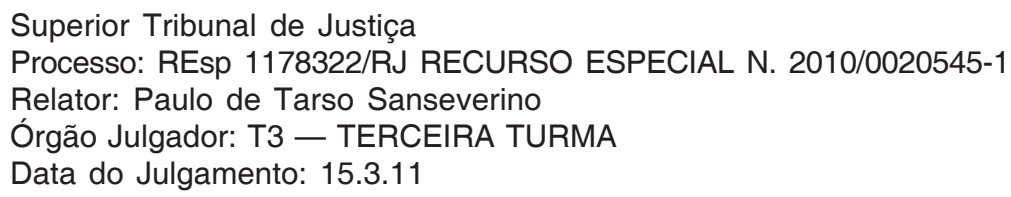

MEIOS DE CONTROLE EM DIREITO SANITÁRIO. PODER DE POLÍ́CIA. OFERECIMENTO DE BEBIDAS ALCÓOLICAS PARA CONSUMO LOCAL E LOCALIZAÇÃO EM ÁREA RURAL ÀS MARGENS DE RODOVIA FEDERAL. 1. Segundo a premissa de fato fixada pelo tribunal de origem, a recorrida encontra-se em área rural, às margens da rodovia federal, e oferece bebidas alcóolicas para consumo no local, embora não constitua empresa precipuamente destinada ao comércio de bebidas alcóolicas, já que sua atividade é no ramo de motel. 2. Vê-se que a recorrida se enquadra perfeitamente na parte final do caput do art. $2^{\circ}$ e no art. $3^{\circ}$ da Lei n. 11.705/08, já que tais normas se aplicam inclusive às empresas não precipuamente destinadas ao comércio de bebidas alcóolicas, notadamente quando não há provas de estar o estabelecimento localizado em área urbana. 3. Não é demais observar que, à luz do princípio da proporcionalidade, diante das condições fáticas e jurídicas do caso, nada mais houve senão a ponderação entre a relevância da proteção à vida, à saúde, à incolumidade física dos indivíduos, de um lado, e, de outro, a preservação da liberdade de comércio, da propriedade, da livre-iniciativa e outros direitos de defesa assegurados constitucionalmente, o que justifica a atuação do Estado editando atos normativos como a lei em testilha. 4. Recurso especial conhecido e provido. Acórdão. Vistos, relatados e discutidos esses autos em que são partes as acima indicadas, acordam os Ministros da SEGUNDA TURMA do Superior Tribunal de Justiça, na conformidade dos votos e das notas taquigráficas, o seguinte resultado de julgamento: "A Turma, por unanimidade, deu provimento ao recurso, nos termos do voto do Sr. Ministro Relator, sem destaque." Os Srs. Ministros Cesar Asfor Rocha, Castro Meira, Humberto Martins (Presidente) e Herman Benjamin votaram com o Sr. Ministro Relator.

Superior Tribunal de Justiça

Processo: REsp 1127179/RS RECURSO ESPECIAL 2009/0043019-0

Relator: Mauro Campbell Marques

Órgão Julgador: T2 — SEGUNDA TURMA

Data do Julgamento: 15.3.11 
DIREITO SANITÁRIO CONSUMERISTA. DIREITO À INFORMAÇÃO ADEQUADA. PROTEÇÃO À SAÚDE. 1. A motivação contrária ao interesse da parte ou mesmo omissa em relação a pontos considerados irrelevantes pelo decisum não se traduz em insuficiência de fundamentação do julgado, sendo descabido, na hipótese, falar em ofensa aos arts. 165, 458, II e III, e 515, do CPC. 2. São legitimados para sua propositura, além do Ministério Público, detentor da função institucional de fazê-lo no resguardo de interesses difusos e coletivos (CF/88, art. 129, III), a União, os Estados, os Municípios, as Autarquias, as empresas públicas, as sociedades de economia mista e as associações civis. 3. Não se exige das associações civis que atuam em defesa aos interesses do consumidor, como sói ser a ora recorrida, autorização expressa de seus associados para o ajuizamento de ação civil que tenha por objeto a tutela a direitos difusos dos consumidores, mesmo porque, sendo referidos direitos metaindividuais, de natureza indivisível, e especialmente, comuns a toda uma categoria de pessoas não determináveis que se encontram unidas em razão de uma situação de fato, impossível seria a individualização de cada potencial interessado. 4. À luz dos enunciados sumulares n. s 282/STF e 356/STF, é inadmissível o recurso especial que demande a apreciação de matéria sobre a qual não tenha se pronunciado a Corte de origem. 5. Inexistindo nos autos elementos que conduzam à necessidade de formação de litisconsórcio passivo necessário da União com a recorrente, já que a demanda diz respeito exclusivamente às informações contidas no rótulo de uma das marcas de cerveja desta, não há falar, in casu, em competência da Justiça Federal. 6. A comercialização de cerveja com teor alcoólico, ainda que inferior a $0,5 \%$ em cada volume, com informação ao consumidor, no rótulo do produto, de que se trata de bebida sem álcool, a par de inverídica, vulnera o disposto nos arts. $6^{\circ}$ e $9^{\circ}$ do CDC, ante o risco à saúde de pessoas impedidas ao consumo. 7. O fato de ser atribuição do Ministério da Agricultura a padronização, a classificação, o registro, a inspeção, a produção e a fiscalização de bebidas, não autoriza a empresa fabricante de, na eventual omissão deste, acerca de todas as exigências que se revelem protetivas dos interesses do consumidor, malferir o direito básico deste à informação adequada e clara acerca de seus produtos. 8. A dispensa da indicação no rótulo do produto do conteúdo alcóolico, prevista no já revogado art. 66, III, "a", do Decreto n. 2.314/97, não autorizava a empresa fabricante a fazer constar neste mesmo rótulo a não veraz informação de que o consumidor estaria diante de cerveja "sem álcool", mesmo porque referida norma, por seu caráter regulamentar, não poderia infirmar os preceitos insculpidos no Código de Defesa do Consumidor. 9. O reexame do conjunto fático-probatório carreado aos autos é atividade vedada a esta Corte superior, na via especial, nos expressos termos do enunciado sumular $\mathrm{n} .07$ do STJ. 10. Recurso especial a que se nega provimento. Acórdão. Vistos, relatados e discutidos estes autos, acordam os Ministros da Terceira Turma do Superior Tribunal de Justiça, prosseguindo no julgamento, após o voto-vista da Sra. Ministra Nancy Andrighi, por unanimidade, negar provimento 
ao recurso especial, nos termos do voto do(a) Sr(a). Ministro(a) Relator(a). Os Srs. Ministros Nancy Andrighi, Massami Uyeda e Paulo de Tarso Sanseverino votaram com o Sr. Ministro Relator. Impedido o Sr. Ministro Sidnei Beneti.

Superior Tribunal de Justiça

Processo: REsp 1181066/RS RECURSO ESPECIAL 2010/0031557-0

Relator: Vasco Della Giustina (Desembargador convocado do TJ/RS)

Órgão Julgador: T3 - TERCEIRA TURMA

Data do Julgamento: 15.3.11

DIREITO PÚBLICO DA SAÚDE. ADMINISTRATIVO. FORNECIMENTO DE MEDICAMENTO. 1. É comum, durante um tratamento médico, haver alteração dos fármacos, sem resultar em ofensa ao art. 264 do CPC. Levando-se em conta que o ordenamento constitucional garante a todos o direito à saúde, a simples troca nos medicamentos postulados na inicial não configura modificação do pedido, o qual é o próprio tratamento médico. Precedentes do STJ. 2. Agravo Regimental não provido. Acórdão. Vistos, relatados e discutidos os autos em que são partes as acima indicadas, acordam os Ministros da Segunda Turma do Superior Tribunal de Justiça: "A Turma, por unanimidade, negou provimento ao agravo regimental, nos termos do voto do Sr. Ministro Relator, sem destaque." Os Srs. Ministros Mauro Campbell Marques, Cesar Asfor Rocha, Castro Meira e Humberto Martins (Presidente) votaram com o Sr. Ministro Relator.

Superior Tribunal de Justiça

Processo: AgRg no REsp 1222387/RS AGRAVO REGIMENTAL NO RECURSO ESPECIAL 2010/0215583-2

Relator: Herman Benjamin

Órgão Julgador: T2 - SEGUNDA TURMA

Data do Julgamento: 15.3.11

MEIOS DE CONTROLE EM DIREITO SANITÁRIO. EXERCÍCIO PROFISSIONAL. PRESENÇA ININTERRUPTA DE ENFERMEIROS: DEVIDA "SI ET IN QUANTUM" (ART. 273/CPC) 1 - Dado que, de regra, o TRF1/T7 (AC n. 2003.38.00.030400-5/AC), alicerçado em precedentes do STJ, examinando a legislação correlata de regência (Leis n. 5.905/1973 e n. 7.498/ 1986 e Resolução COFEN N. 146/1992), entende necessária a presença permanente e exclusiva de enfermeiros para orientar técnicos/auxiliares de enfermagem, tal convicção mais avulta no caso (em cognição sumária), porque a atividade desenvolvida pela ré é de risco sensível (serviços médicos/ psicológicos a pacientes com psicoses, neuroses graves e dependentes químicos) e a verificação da ausência dos profissionais se deu como desdobramento de fiscalização iniciada por ação do Ministério Público do Trabalho (MPT) e da Promotoria de Justiça de Defesa da Saúde do MPDFT: a manutenção de enfermeiro em todo o período de atividade da ré é, no momento, salva cognição exauriente, medida que se impõe em antecipação de tutela. 2 - Pode-se discordar - aspecto técnico discricionário - sobre 
"quantos enfermeiros são necessários para quantos técnicos/auxiliares", mas não se pode opor óbice ao fato de que eles devem estar presentes em quantidade suficiente no nosocômio, de modo ininterrupto e permanente, para que se possa atingir ao fim colimado pela Lei n. 7.498/1986. 3 - Agravo de Instrumento provido. 4 - Peças liberadas pelo Relator, em Brasília, 29 de março de 2011., para publicação do acórdão. Decisão: A Turma DEU PROVIMENTO ao agravo de instrumento por unanimidade.

Tribunal Regional Federal 1a Região

Processo: AG 0065382-23.2010.4.01.0000/DF; AGRAVO DE INSTRUMENTO

Relator: Luciano Tolentino Amaral

Órgão Julgador: SÉTIMA TURMA

Julgamento: 29.3.11

MEIOS DE CONTROLE EM DIREITO SANITÁRIO. VIGILÂNCIA SANITÁRIA. 1. A Lei $n$. 8.080/1990 confere à administração pública a obrigação legal de promover a regulação e a fiscalização dos serviços de saúde. 2. Inexiste, assim, direito líquido e certo, na hipótese, em que se pretende tolher o desempenho de regular atividade estatal. 3. Ademais, o impetrante não demonstrou, em nenhum momento, o efetivo prejuízo que a atividade fiscalizadora, com fundamento no PNASH, possa causar a seus filiados. 4. Sentença confirmada. 5. Apelação desprovida. Decisão: A Turma, por unanimidade, negou provimento à apelação.

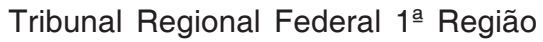

Processo: AMS 0036586-12.2007.4.01.3400/DF; APELAÇÃO EM MANDADO DE SEGURANÇA

Relator: Daniel Paes Ribeiro

Órgão Julgador: SEXTA TURMA

Julgamento: 14.3.11

MEIOS DE CONTROLE EM DIREITO SANITÁRIO. VIGILÂNCIA SANITÁRIA. PROPRIEDADE INDUSTRIAL. ANVISA. ANUÊNCIA PRÉVIA. I — Entidades Estatais não podem abandonar, alterar ou modificar os objetivos institucionais a que vinculados pela lei de criação/fundação - princípio administrativo da especialidade - CF art. 37, XIX. II - INPI — Leis n. 5.648/70 e n. 9.279/98 finalidade de executar as normas que regulam a propriedade industrial. III ANVISA — Lei n. 9.782/99 — finalidade de promover a proteção da saúde da população, por intermédio de controle sanitário da produção e da comercialização de produtos e serviços submetidos à vigilância sanitária. IV - Lei posterior, cuja norma não tenha expressamente alterada a finalidade institucional, não pode acrescer rol de atribuições por mera interpretação extensiva ou integração.V - Em questão de patente de fármacos não pode a ANVISA reavaliar os requisitos de patenteados, exceto no que diz respeito ao risco, ainda que apenas potencialmente, de causar mal à saúde ou quando 
houver dúvidas sobre a sua eficácia. VI - Não são patenteáveis o que for contrário à moral, aos bons costumes, à segurança, à ordem e à SAÚDE públicas. VII — Patente requerida há cerca de 10 (dez) anos sem anuência da ANVISA com base apenas em regras de patenteabilidade, demonstra necessidade de antecipação parcial dos efeitos da tutela, para determinar à ANVISA reexame do pleito administrativo com vistas à sua finalidade precípua (riscos à saúde humana e/ou eficácia duvidosa). VIII — Agravo de Instrumento parcialmente provido, antecipada, em parte, o efeito da tutela na ação ordinária em curso perante a instância monocrática, item VII. Decisão: A Turma, por unanimidade, deu parcial provimento ao agravo de instrumento.

Tribunal Regional Federal 1 ${ }^{\mathrm{a}}$ Região

Processo: AG 0070304-44.2009.4.01.0000/DF; AGRAVO DE INSTRUMENTO

Relator: Jirair Aram Meguerian

Órgão Julgador: SEXTA TURMA

Julgamento: 14.3.11

DIREITO CIVIL DA SAÚDE. RESPONSABILIDADE OBJETIVA. ERRO DE DIAGNÓSTICO. 1. Ante a ocorrência de grave dano moral à parturiente, por diagnóstico equivocado de AIDS, comprovado está o nexo de causalidade entre o ato do hospital público e o referido dano, razão por que se acha caracterizada a responsabilidade civil objetiva do Estado (CF, art. 37, § 6). Precedentes. 2. Caso em que a autora, em trabalho de parto, após realizar exame de sangue em maternidade pública, recebeu resultado de que era portadora do vírus do HIV, tendo sido, por isso, submetida a cesariana e, após realização de outro exame, com novo resultado positivo, mas negativo para o consorte-varão, foi separada da filha, recém-nascida, e impedida de amamentá-la logo após o parto, sendo ambas submetidas ao uso de AZT. Todavia, nos dias que se seguiram, ao realizar novo exame, no próprio hospital, assim como outro exame, um mês depois, em outro laboratório, recebeu resultado diverso, atestando a ausência do vírus HIV. 3. A par de a conduta do hospital ter sido a mais indicada para os casos da espécie, isso, entretanto, não afasta os graves traumas, induvidosos, decorrentes do erro de diagnóstico quanto a enfermidade, assaz grave, como sucedeu no caso (AIDS). De efeito, é bastante traumático para uma pessoa receber a notícia de que é portadora de uma doença que, via de regra, é tão degradante, acarretando dor física e emocional. Além de ocasionar a morte, ainda expõe o seu portador a discriminação e sobrevida, em geral, de péssima qualidade. 4. As consequências são ainda mais danosas em se tratando de mulher grávida, prestes a dar à luz, que se viu sem chance de tentar parto normal, bem assim privada de amamentar seu rebento e tê-lo ao seu lado ao término do parto. A questão da amamentação é de extrema importância, não só para a satisfação pessoal da mãe, mas para saúde psicológica e física da recémnascida. Acresce a circunstância de que a mãe se achava em situação de 
fragilidade física e psicológica e foi submetida a forte medicação (AZT), cujos efeitos colaterais são sabidamente ocorrentes. 5. Some-se, ainda, a situação vexatória a que foi submetida a parturiente, diante do seu marido, tanto mais porque este teve o resultado negativo para HIV, o que pode ter gerado naturais dúvidas quanto à fidelidade conjugal da esposa. Isto é, houve risco, até mesmo, de ruptura da entidade familiar. 6. A questão referente aos maustratos no hospital, entretanto, não foi suficientemente comprovada. 7. Majorase o montante da condenação, fixada em $R \$ 15.500,00$, a título de danos morais, para $R \$ 18.000,00$, a fim de adequá-lo ao precedente da Quinta Turma, da lavra do juiz então convocado, Avio Mozar Jose Ferraz de Novaes, na AC 1999.36.00.006117-3/MT, e-DJF1 de 21/02/2008. 8. Apelação da UFBA desprovida. 9. Apelação da autora provida a fim de majorar para $R \$$ 18.000,00 (dezoito mil reais) o valor da condenação a título de danos morais. Decisão: A Turma, por unanimidade, negou provimento à apelação da UFBA, e deu provimento ao apelo da autora.

Tribunal Regional Federal 1a Região

Processo: AC 0017277-48.2006.4.01.3300/BA; APELAÇÃO CÍVEL

Relator: Fagundes de Deus

Órgão Julgador: QUINTA TURMA

Julgamento: 16.3.11

DIREITO PÚBLICO DA SAÚdE. RELEVÂNCIA. PÚBLICA. AGÊNCIA NACIONAL DE SAÚDE SUPLEMENTAR. 1. As pessoas jurídicas constituídas com o fito de desenvolver atividades relacionadas à prestação de serviços de assistência de saúde suplementar, ante a relevância pública de seu mister, visto que o bem tutelado é a saúde e a vida, devem se submeter a determinado tipo de ingerência estatal, conforme deflui do disposto no art. 197 da Constituição Federal, segundo o qual são de relevância pública as ações e serviços de saúde, cabendo ao poder público dispor, nos termos da lei, sobre sua regulamentação, fiscalização e controle, devendo sua execução ser feita diretamente ou através de terceiros e, também, por pessoa física ou jurídica de direito privado. 2. A garantia prevista no art. 50, inciso XVIII, da Constituição Federal, deve estar adstrita à não interferência do Estado na relação jurídica estabelecida entre a entidade cooperativa e seus cooperativados, sendo certo que os atos interna corporis alusivos a esta relação refogem à ingerência estatal, que apenas se estabelece a partir do momento em que as cooperativas de trabalho médico, ao introduzirem no mercado interno planos privados de assistência à saúde, passam a afetar a sociedade. 3. As empresas operadoras de planos de saúde, independentemente da forma jurídica como se encontram constituídas (cooperativas, sociedades civis ou comerciais), subsumem-se às regras constitucionais pertinentes aos princípios gerais da ordem econômica e, por conseguinte, aos ditames do art. 174 da CRFB/88, que preconiza o dever do Estado de, na qualidade de agente normativo e regulador da atividade econômica, exercer as funções de fiscalização, incentivo e planejamento. 4. Não é razoável que as 
cooperativas de trabalho médico se eximam dos desígnios firmados pelas Leis ns. 9.656/98 e 9.961/00, em virtude da dicção do art. 5º, inciso XVIII, da $\mathrm{CRFB} / 88$, até porque os indigitados diplomas legais não impediram a criação ou o funcionamento destas entidades, mas apenas estabeleceram parâmetros básicos para uma satisfatória prestação de serviços aos adquirentes dos planos de saúde por elas comercializados. Recurso improvido. Sentença mantida. Precedente: AC n. 2003.51.01.014221-5/RJ — Relator DF Sergio Schwaitzer - DJU:23/06/2005. 5.

Tribunal Regional Federal 2a ${ }^{\mathrm{a}}$.RegiãoAcórdão

Processo: 2002.51.01.025346-0 — AC — APELAÇÃO CÍVEL — 428471

Orgão Julgador: SEXTA TURMA ESPECIALIZADA

Julgamento: 28.3.11

DIREITO PÚBLICO DA SAÚDE. FEDERALISMO. FORNECIMENTO DE MEDICAMENTOS. Em sede de fornecimento de medicamentos, são solidariamente responsáveis a União, o Estado e o Município. Caso em que, de acordo com informações dos autos, o medicamento requerido está previsto no rol do Programa de Assistência Farmacêutica para a Atenção Básica do SUS. O fornecimento se impõe, e a previsão no Programa não afasta a pretensão autoral. Logo, deve ser entregue o medicamento, na forma prescrita pelo médico. Verifica-se que a sentença é ultra petita, pois a pretensão do autor é referente apenas ao fornecimento o medicamento "DARUNAVIR 300 mg" (fls. 7/8), e não à prestação de exames laboratoriais também determinado na decisão. Assim, impõe-se, por conseguinte, a redução da sentença aos limites do pedido. Honorários advocatícios moderadamente fixados na sentença, em 5\% (cinco por cento) sobre o valor da causa. Remessa necessária e apelação da União parcialmente provida. Apelo do Município do Estado do Rio de Janeiro desprovido.

Tribunal Regional Federal 2a ${ }^{-}$Região

Processo: 2008.51.01.000851-0 - APELREEX - APELAÇÃO/

REEXAME NECESSÁRIO - 506849

Orgão Julgador: SEXTA TURMA ESPECIALIZADA

Julgamento: 28.3.11

DIREITO PÚBLICO DA SAÚDE. FORNECIMENTO DE MEDICAÇÃO. 1. Não há falar-se em falta de comprovação da negativa administrativa do pleito, a gerar falta de interesse de agir. De fato, a própria resistência da União, a insurgir-se contra o pedido através desta apelação já demonstra a necessidade de obtenção da tutela jurisdicional, restando atendida a condição da ação acima referida. 2. Não se verifica motivação plausível para a negativa da medicação ao paciente quando este é necessário - o genótipo da paciente requer o tipo de interferon requisitado - e quando a negativa se estriba em vedação regulamentar invencível para a autora. Explica-se: a Fazenda estadual argumenta que seria necessária a realização de biópsia 
do fígado para que se cumpra o protocolo da Portaria 863/2002, mas é dos autos que a paciente tem sérias dificuldades de coagulação e se encontra, pois, impossibilitada de realizar a biópsia exigida (fls. 11). Alias, já foram feitas três tentativas malsucedidas, conforme se verifica do mesmo documento médico. 3. Não pode prevalecer, portanto, uma regulamentação proibitiva genérica de um ato administrativo quando as circunstâncias concretas apontam a necessidade de fornecimento dos medicamentos referidos. Negar tal direito seria negar o direito à saúde a partir de uma interpretação burocrática injustificável. 4. Apelações e remessa oficial improvidas.

Tribunal Regional Federal 2a ${ }^{a}$ Região

Processo: 2003.61.26.007326-1 — AC — APELAÇÃO CÍVEL — 1146556

Relator: Juiz Convocado Leonel Ferreira

Órgão Julgador: TURMA D

Julgamento: 30.3 .11

MEIOS DE CONTROLE EM DIREITO SANITÁRIO. EXERCÍCIO PROFISSIONAL. RESPONSABILIDADE TÉCNICA. 1. Encontra-se pacificada a jurisprudência, firme no sentido de que a lei não exige a contratação de responsável técnico farmacêutico em dispensários de unidades hospitalares, em que não existe manipulação de fórmulas nem fornecimento de medicamentos ao público em geral, mas tão somente aos próprios pacientes, diretamente assistidos por médicos. 2. Nem cabe cogitar de violação ao princípio da isonomia, da proporcionalidade ou ao direito universal à saúde, nem a de que seria absurdo a aplicação de súmula de jurisprudência consolidada, pois evidenciada sua compatibilidade com a própria Lei n. 5.991/ 73, ao referir-se ao dispensário de medicamentos como setor de fornecimento de medicamentos de unidade hospitalar, distinguindo situações jurídicas mediante critério objetivo e sem qualquer ofensa à garantia universal da saúde, vez que preservada a assistência médica na prescrição medicamentosa para público restrito em âmbito hospitalar específico, sem risco à dignidade da pessoa humana, conforme reconhecido pela jurisprudência. 3. A base legal para a exigência de responsável técnico é o art. 15 da Lei n. 5.991/73, cuja interpretação não admite a inclusão, no alcance impositivo da norma, dos dispensários de medicamentos de hospitais, que não são farmácias nem drogarias. A invocação da Súmula 140/TFR vale pela prevalência que confere ao princípio da legalidade como única fonte normativa válida para impor restrição à liberdade de ação, constitucionalmente assegurada. A alegação de que o Ministério da Saúde editou portarias (1.044/04 e 4.283/ 10) é irrelevante, pois o administrador não pode, por ato administrativo, criar dever, restrição e sanção inexistentes na disciplina legal específica, contrariando não apenas a norma, a vontade do legislador, como a própria lógica do sistema legal, que excluiu os dispensários hospitalares de medicamento da exigência de contratação de responsável técnico, por não 
atuarem na manipulação de fórmulas nem no fornecimento de medicamentos ao público em geral. 4. Apelação e remessa oficial desprovidas.

Tribunal Regional Federal 2 ${ }^{\mathrm{a}}$ Região

Processo: 2009.61.00.020795-4 — APELAÇÃO EM MANDADO DE SEGURANÇA - 323915

Relator: Nery Junior

Órgão Julgador: TERCEIRA TURMA

Julgamento: 31.3.11

DIREITO PÚBLICO SANITÁRIO. FEDERALISMO. FORNECEMENTO DE MEDICAÇÃO. LITISCONSÓRCIO PASSIVO FACULTATIVO. Trata-se de agravo de instrumento interposto contra despacho/decisão exarado(a) na Ação Ordinária n. 2009.72.11.001987-6/SC (fls. 53/54), nos seguintes termos: "Trata-se de ação ordinária ajuizada, originariamente perante a Comarca de Curitibanos/SC, por EVELYN DEPINE WESTPHAL, neste ato representada por sua mãe KELLY CRISTINA DEPINE em face do ESTADO DE SANTA CATARINA e do MUNICÍPIO DE CURITIBANOS, na qual postula a autora, inclusive em sede de antecipação dos efeitos da tutela, sejam os réus compelidos ao fornecimento de medicamento em seu favor. O Estado de Santa Catarina, em sua contestação, pugnou pelo chamamento ao processo da União. É o breve relato. Decido. A controvérsia, neste momento processual, inclusive por se tratar de matéria de ordem pública - fixação de competência —, reside em reconhecer-se ou não o litisconsórcio passivo necessário entre a União Federal, Estado e Município, em demanda cuja causa de pedir é a negativa, pelo SUS (seja pelo gestor municipal, estadual ou federal), de prestação na área de saúde, tais como o fornecimento de medicamento, ou seu custeio, em favor de pessoas desprovidas de recursos financeiros. Nesses casos, até um passado não muito distante, vinha decidindo pela ausência de litisconsórcio passivo necessário, a despeito da solidariedade entre os entes federados, e rejeitando, via de consequência, o chamamento ao processo da União. Todavia, nada obstante o tratamento que vinha sendo dado ao tema por este juízo com base em precedentes diversos do TRF4 e do STJ, a jurisprudência oscilou, posteriormente, passando a admiti-lo. Entretanto, mais recentemente, parece-nos que a situação mudou. Isso porque desponta na jurisprudência do TRF4 e do STJ a consolidação da tese que aponta para a rejeição do chamamento ao processo da União Federal, em ações que versam sobre o fornecimento de medicamentos, ao reconhecer que, a despeito da solidariedade entre os entes federados, não se trata de litisconsórcio passivo necessário, de tal forma que, se a parte autora escolhe litigar somente contra um ou dois dos entes federados, não há obrigatoriedade de inclusão dos demais. Nesse sentido, trago à colação recentes e elucidativos precedentes das $3^{\underline{a}}$ e 4 ${ }^{a}$ Turmas do Egrégio Tribunal Regional Federal da 4 ${ }^{a}$ Região, verbis: ADMINISTRATIVO E CONSTITUCIONAL. FORNECIMENTO DE MEDICAMENTOS. ENTES POLÍTICOS - RESPONSABILIDADE SOLIDÁRIA. INEXISTÊNCIA DE LITISCONSÓRCIO NECESSÁRIO. DIREITO AO 
RECEBIMENTO DE MEDICAMENTOS - REQUISITOS. CRITÉRIOS PARA PONDERAÇÃO. ANÁLISE DE CASO CONCRETO. HONORÁRIOS ADVOCATÍCIOS - REFORMATIO IN PEJUS. 1. A União, Estados-Membros e Municípios têm legitimidade passiva e responsabilidade solidária nas causas que versam sobre fornecimento de medicamentos. 2. A jurisprudência da Turma é firme no sentido de que, em se tratando de fornecimento de medicamentos, existe solidariedade entre os entes da Federação, mas não litisconsórcio necessário. (grifei) (APELREEX 00025157820094047005, 3 $3^{\text {a }}$ Turma, Relator Guilherme Beltrami, por unanimidade, D.E. 06.10.2010). PROCESSUAL CIVIL. AGRAVO EM AGRAVO DE INSTRUMENTO. FORNECIMENTO DE MEDICAMENTO. CHAMAMENTO AO PROCESSO. Se a parte escolhe litigar somente contra um ou dois dos entes federados, não há a obrigatoriedade de inclusão dos demais. Agravo desprovido. (AG 00057698820104040000, 3 ${ }^{\mathrm{a}}$ Turma, Relator Carlos Eduardo Thompson, por unanimidade, D.E. 12/05/2010). PROCESSUAL CIVIL. MEDICAMENTOS. LEGITIMDIADE. SOLIDARIEDADE. LITISCONSÓRCIO PASSIVO FACULTATIVO. Havendo solidariedade passiva entre os entes federados no que se refere ao fornecimento de medicamentos, não há falar em litisconsórcio passivo necessário. Tratando-se da hipótese de litisconsórcio facultativo e excluído o ente que justificava a tramitação do feito da Justiça Federal, correta a decisão que determina a devolução dos autos à Justiça Estadual. (AG 00045175020104040000, Relatora Marga Inge Barth Tessler, 4⿳亠丷厂 Turma, por unanimidade, D.E. 24/05/2010). E, na mesma linha de entendimento, colaciono precedente da $1^{\text {a }}$ Seção do Superior Tribunal de Justiça: PROCESSUAL CIVIL. CONFLITO NEGATIVO DE COMPETÉNCIA. JUÍZO FEDERAL E JUÍZO ESTADUAL. AÇÃO ORDINÁRIA. FORNECIMENTO DE MEDICAMENTOS. AUSÊNCIA DE INTERESSE DA UNIÃO DA LIDE. ART. 109, I, DA CF/88. INCIDÊNCIA DAS SÚMULAS 150 E 254 DO STJ. COMPETÊNCIA DA JUSTIÇA ESTADUAL. (...) 2. O interesse jurídico da União, in casu, foi afastado pelo Juízo Federal, que, por seu turno, indeferiu expressamente o pleito de chamamento da pessoa jurídica de direito público ao feito. 3. Inteligência das Súmulas 150 e 254 do STJ. Súmula 150: Compete à Justiça Federal decidir sobre a existência de interesse jurídico que justifique a presença da União, no processo, da União, suas Autarquias ou Empresas Públicas. Súmula 254: A decisão do Juízo Federal que exclui da relação processual ente federal não pode ser reexaminada no Juízo Estadual. (...) (AGRCC - AGRAVO REGIMENTAL NO CONFLITO DE COMPETÊNCIA 108289, Primeira Seção, Relator LUIZ FUX, por unanimidade, DJE: 22/09/ 2010). Por conseguinte, tratando-se de litisconsórcio passivo facultativo, impõe-se não só a exclusão da União Federal do polo passivo da presente demanda, mas também a devolução dos autos à Justiça Estadual, juízo competente para apreciar e julgar o presente feito. Diante do exposto, rejeito o chamamento ao processo da União, e determino: a) a sua exclusão do polo passivo da presente demanda, nos termos da fundamentação supra, e, por conseguinte, b) a devolução dos presentes autos à Comarca de Curitibanos/ 
SC. Intime(m)-se. Operada a preclusão, remetam-se os autos ao juízo competente. Cópia deste despacho servirá como carta de intimação ao Estado de Santa Catarina e ao Município de Curitibanos/SC. Caçador, 01 de fevereiro de 2011. (a) EDUARDO CORREIA DA SILVA — Juiz Federal Substituto". É o sucinto relato. Decido. A ação de origem foi ajuizada na Justiça Estadual contra o Estado de Santa Catarina. Este, por sua vez, ao contestar o feito, postulou o chamamento ao processo da União. O art. 196 da Constituição Federal de 1988 dispõe que "a saúde é direito de todos e dever do Estado, garantido mediante políticas sociais e econômicas que visem à redução do risco de doença e de outros agravos e ao acesso universal e igualitário às ações e serviços para sua promoção, proteção e recuperação". O § 1ำ do art. 198, a seu turno, determina que "o sistema único de saúde será financiado, nos termos do art. 195, com recursos do orçamento da seguridade social, da União, dos Estados, do Distrito Federal e dos Municípios, além de outras fontes". À União incumbe a gestão e o financiamento do Sistema Único de Saúde - SUS, enquanto que, aos Estados, Municípios e Distrito Federal, cabe a execução de suas atividades, consoante descentralização das ações de serviço de saúde, circunstância esta que, por si só, permite a eleição, pela parte demandante, daqueles contra quem pretende demandar, inclusive isoladamente. Daí falar-se em obrigação solidária, pois, da mesma obrigação (prestacional) concorre mais de um devedor, cada um obrigado à dívida toda (art. 264, Código Civil). O direito social à saúde, previsto no art. 6ํ da Carta Magna, pode ser pleiteado pelo cidadão frente a qualquer dos três entes estatais. Sobre o tema já se manifestou o STF no RE 195.192-3/RS, no RE 280.642/RS, e, recentemente, nas Suspensões de Tutela Antecipada 175 e 178: EMENTA: Suspensão de Segurança. Agravo Regimental. Saúde pública. Direitos fundamentais sociais. Art. 196 da Constituição. Audiência Pública. Sistema Único de Saúde - SUS. Políticas públicas. Judicialização do direito à saúde. Separação de poderes. Parâmetros para solução judicial dos casos concretos que envolvem direito à saúde. Responsabilidade solidária dos entes da Federação em matéria de saúde. Fornecimento de medicamento: Zavesca (miglustat). Fármaco registrado na ANVISA. Não comprovação de grave lesão à ordem, à economia, à saúde e à segurança públicas. Possibilidade de ocorrência de dano inverso. Agravo regimental a que se nega provimento.(STA 175 AgR, Relator(a): Min. GILMAR MENDES (Presidente), Tribunal Pleno, julgado em 17/03/2010, DJe-076 DIVULG. 2904-2010 PUBLIC. 30-04-2010 EMENT. VOL. 02399-01 PP-00070) Também o STJ possui o mesmo entendimento: PROCESSUAL CIVIL. RECURSO ESPECIAL. ART. 105, III, "B". EMENDA CONSTITUCIONAL N. 45/2004. HONORÁRIOS DE ADVOGADO DEVIDOS PELO ESTADO À DEFENSORIA PÚBLICA. IMPOSSIBILIDADE. CONFUSÃO. ART. 1.049 DO CÓDIGO CIVIL DE 1916. SISTEMA ÚNICO DE SAÚDE — SUS. FORNECIMENTO DE MEDICAMENTOS. RESPONSABILIDADE SOLIDÁRIA DOS ENTES FEDERATIVOS. (...) 4. Sendo o Sistema Único de Saúde (SUS) composto pela União, Estados-Membros, Distrito Federal e Municípios, impõe-se o 
reconhecimento da responsabilidade solidária dos aludidos entes federativos, de modo que qualquer um deles tem legitimidade para figurar no polo passivo das demandas que objetivam assegurar o acesso à medicação para pessoas desprovidas de recursos financeiros. 5. Recurso especial parcialmente provido. (REsp 674.803/RJ, Rel. Ministro JOÃO OTÁVIO DE NORONHA, SEGUNDA TURMA, julgado em 15.02.2007, DJ 06.03.2007 p. 251) Em sendo reconhecida a solidariedade entre os entes políticos, nos termos do art. 46 do Estatuto Processual Civil, é possível litigar, no mesmo processo, contra um ou mais devedores. Inexiste, no caso, litisconsórcio passivo necessário, mas, antes, facultativo, cabendo à parte a escolha daquele contra quem deseja litigar, sem obrigatoriedade de inclusão dos demais. O Estado de Santa Catarina postula o chamamento ao processo da União, com base no art. 77, inciso III, do CPC, por entender que, ao estar configurada a responsabilidade solidária, seria cabível tal intervenção: Art. 77. É admissível o chamamento ao processo: I - (...); II - (...); III — de todos os devedores solidários, quando o credor exigir de um ou de alguns deles, parcial ou totalmente, a dívida comum. Ocorre que, segundo demonstra Athos Gusmão Carneiro (Intervenção de Terceiros, 15ā ed., Saraiva, 2003, p. 152-164), é necessário o preenchimento de dois pressupostos para o seu deferimento. 0 primeiro exige que o chamado seja também devedor da obrigação frente ao credor, em caráter principal ou subsidiário. O segundo requer que, em face da relação de direito material deduzida em juízo, o pagamento da dívida pelo "chamante" dê a este o direito de reembolso, total ou parcialmente, contra o chamado. O ilustre Ministro aposentado cita lição de Vicente Greco Filho (Da intervenção de terceiro, $2^{a}$ ed., Saraiva, 1986, p. 96), segundo o qual "ao réu não assiste interesse processual em chamar o terceiro como seu litisconsorte se não puder, pelo menos em tese, exercer posteriormente direito de regresso contra ele. O chamamento existe por causa da economia processual, como vimos, para atender o interesse do réu coobrigado, não para facilitar o atendimento da pretensão material do autor que escolheu, entre os codevedores, contra quem demandar". Por óbvio, o instituto não beneficia o credor. Antes, o obriga a litigar contra quem não pretendia inicialmente, além de lhe causar tumulto na relação processual inicialmente estabelecida, pois traz à lide relação jurídica diversa. Por isso, não é qualquer responsabilidade solidária que indica a necessidade de se deferir o chamamento ao processo. O "chamante" precisa justificar o seu interesse na participação do "chamado" no processo. Ademais, o chamamento ao processo da União nas hipóteses em que se pleiteia direito relacionado à saúde, desloca a competência do feito necessariamente para a Justiça Federal. Deixa o cidadão de ter o direito de litigar contra o Município ou contra o Estado na Justiça Estadual local, já que, em se tratando de prestação inerente à saúde, não permite a Constituição Federal o ajuizamento do feito em Comarca que não seja sede de vara do juízo federal, a exemplo do que se vislumbra nas hipóteses previstas no art. 109, § 3º, da CF. O direito social à saúde fica, assim, limitado, toda a vez que 
o ente estatal contra quem o cidadão tenha ajuizado a demanda suscite o chamamento ao processo da União. Na grande maioria litigam pessoas hipossuficientes que não têm condições financeiras de arcar com o medicamento/tratamento. Se assim é, com muito mais razão não terão condições econômicas de se deslocar para a Subseção sede da Justiça Federal e pleitear direito que lhes assiste. Em se admitindo o chamamento ao processo amplo e irrestrito, pelo simples fato de se estar diante de responsabilidade solidária, limitar-se-ia consideravelmente o acesso à prestação. E mais, sem qualquer benefício claro e direto para o Estado. Afinal, não prevê a Constituição Federal ou a Lei n. 8.080/90 a obrigação da União em ressarcir o Estado parcial ou totalmente das despesas inerentes ao medicamento/tratamento aqui pleiteado. A distribuição de recursos para os Estados tem regra específica, conforme prevê o art. 35 da Lei n. 8.080/90, e não será majorada necessariamente em virtude do provimento desta ação. Pactuam do entendimento, embora com fundamentos relativamente diversos, a Primeira Turma do STJ e a Terceira Turma desse Tribunal, conforme arrestos abaixo transcritos: PROCESSUAL CIVIL E ADMINISTRATIVO. FORNECIMENTO DE MEDICAMENTO. AÇÃO MOVIDA CONTRA ESTADO. CHAMAMENTO DA UNIÃO AO PROCESSO. CPC, ART. 77, III. INVIABILIDADE. 1. A hipótese de chamamento ao processo prevista no art. 77, III do CPC é típica de obrigações solidárias de pagar quantia. Tratando-se de hipótese excepcional de formação de litisconsórcio passivo facultativo, promovida pelo demandado, não comporta interpretação extensiva para alcançar prestação de entrega de coisa certa, cuja satisfação efetiva não comporta divisão. 2. Recurso Especial improvido. (STJ, REsp 1.125.537/SC, Primeira Turma, Rel. Min. Teori Albino Zavascki, unânime, julgado em 16/03/2010) AGRAVO DE INSTRUMENTO. MEDICAMENTO. SUS. CHAMAMENTO. UNIÃO. DESNECESSIDADE. A responsabilidade é solidária entre as três esferas de governo, o que autoriza a propositura da ação contra um, alguns ou todos os responsáveis solidários, conforme opção do interessado e respeitados os limites subjetivos da lide. Não há a configuração de litisconsórcio necessário. A propositura da ação contra mais de um dos entes responsáveis pelo SUS forma mero litisconsórcio facultativo. (TRF4, AG 2009.04.00.032245-6, Terceira Turma, Relatora Des. Fed. Maria Lúcia Luz Leiria, julgado em 11/05/2010) PROCESSUAL CIVIL. AGRAVO EM AGRAVO DE INSTRUMENTO. FORNECIMENTO DE MEDICAMENTO. CHAMAMENTO AO PROCESSO. Se a parte escolhe litigar somente contra um ou dois dos entes federados, não há a obrigatoriedade de inclusão dos demais. Agravo desprovido. (TRF4, AG 000576988.2010.404.0000, Terceira Turma, Relator Des. Fed. Carlos Eduardo Thompson Flores Lenz, julgado em 27/04/2010) Portanto, descabida a pretensão do Estado de promover o chamamento ao processo da União, manejada já quando da distribuição do feito na Justiça Estadual. Como compete à Justiça Federal decidir sobre a existência de interesse jurídico que justifique a sua presença no processo (Súmula 150/STJ), inviável o provimento do recurso. Considerando os princípios da economia e da 
celeridade processuais, bem como a falta de proveito prático voltado contra decisão que somente suspenda a tramitação da ação principal ou eleja o Juízo competente, postergando a discussão central para o futuro, com fulcro no art. 557 do Código de Processo Civil, nego seguimento ao agravo. Publique-se e intimem-se. Decorrido o prazo legal, dê-se baixa na distribuição e remetam-se os autos à Vara de origem.

Tribunal Regional Federal 4⿳亠丷⿵冂⿱十口𧰨 Região

Processo: AG - AGRAVO DE INSTRUMENTO - Acão Ordinária n. 2009.72.11.001987-6/SC

Relatora: Marga Inge Barth Tessler

Julgamento: 7.4.11

MEIOS DE CONTROLE EM DIREITO SANITÁRIO. VIGILÂNCIA SANITÁRIA. BRONZEAMENTO ARTIFICIAL1. A acolhida de agravo de instrumento interposto a hostilizar o deferimento de antecipação de tutela - em ação ordinária tendente à declaração de ilegalidade das Resoluções ANVISA RDC 56/2009 e RE 5.184/09 quanto à proibição da atividade de bronzeamento artificial para fins estéticos - pressupõe vigoroso combate aos fundamentos do decisum, sob pena de malogro. 2. Apelação provida.

Tribunal Regional Federal 4a Região

Processo: Apelação/Reexame Necessário N. 5023613-06.2010.404.7100/

RS

Relator: Carlos Eduardo Thompson Flores Lenz

Julgamento: 19.4.11

DIREITO PÚBLICO DA SAÚDE. ÉTICA SANITÁRIA. FINANCEIRO. OBRA DE EXTREMA IMPORTÂNCIA. 1. Não se pode privar a municipalidade do recebimento de recursos federais - saúde, educação e assistência social, como forma de coerção ao pagamento de dívida ou à prestação de contas. 2. Suficiente a atitude tomada pela atual gestão municipal no sentido de concluir as obras de hospital, obra de extrema importância para a região, conforme comprovam as correspondências enviadas ao Ministério da Saúde e recomendação efetuada pelo Ministério Público Federal. 3. Agravo desprovido.

Tribunal Regional Federal 4⿳亠丷厂 Região

Processo: Agravo em Apelação/Reexame Necessário N. 500037012.2010.404.7204/SC

Relator: Carlos Eduardo Thompson Flores Lenz

Julgamento: 19.4.11

DIREITO PÚBLICO DA SAÚDE. TRIBUTÁRIO. TAXA DE FISCALIZAÇÃO DE VIGILÂNCIA SANITÁRIA. Trata-se de apelação interposta pela AGÊNCIA NACIONAL DE VIGILÂNCIA SANITÁRIA - ANVISA contra sentença de primeira instância que julgou procedente a presente ação ordinária, na qual pretende a autora seja declarada a ilegalidade e inconstitucionalidade da cobrança da Taxa de Fiscalização de Vigilância Sanitária para emissão de autorização para funcionamento de empresa distribuidora de medicamentos. Sustenta a apelante a legalidade e constitucionalidade da Taxa de 
Fiscalização de Vigilância Sanitária cobrada anualmente. Afirma a inexistência de bis in idem entre a taxa de licenciamento estadual e a TFVS. Requer a apreciação do agravo retido. É o relatório. Decido. Do agravo retido: Tendo em vista que o objeto do agravo retido confunde-se com o mérito da ação, será com ele analisado. Do mérito: A parte autora insurge-se contra o pagamento de taxa para renovar sua autorização de funcionamento como distribuidora de medicamentos. A Lei n. 9.782, de 26 de janeiro de 1999, instituiu a referida Taxa de Fiscalização de Vigilância Sanitária, devida à ANVISA, nos seguintes termos: Art. 23. Fica instituída a Taxa de Fiscalização de Vigilância Sanitária. $§ 1^{\circ}$ Constitui fato gerador da Taxa de Fiscalização de Vigilância Sanitária a prática dos atos de competência da Agência Nacional de Vigilância Sanitária constantes do Anexo II. O Anexo II da referida lei passou a vigorar na forma do Anexo da Medida Provisória n. 2190-34/2001. Segundo suas disposições, constitui fato gerador da taxa de fiscalização e vigilância sanitária (item 3.1.5) a "Autorização e autorização especial de funcionamento de empresa, bem como as respectivas renovações. A pretensão da apelante não procede. Mantida a atividade principal da empresa, deverá pagar a taxa relativa a autorização para funcionamento ou renovação. Compulsando a Lei n. 9.782/99, se extrai que ao Sistema Nacional de Vigilância Sanitária cabe a atividade de regulação, normatização, controle e fiscalização na área de vigilância sanitária. Sendo que a competência de fiscalização da União será exercida pela Agência Nacional de Vigilância Sanitária, autarquia vinculada ao Ministério da Saúde e com atuação em todo o território nacional, podendo delegar aos Estados, ao Distrito Federal e aos Municípios a execução de atribuições que lhe são próprias, excetuadas as previstas nos incisos I, V, VIII, IX, XV, XVI, XVII, XVIII e XIX do art. 7ํ da lei em referência. Ou seja, a administração e arrecadação da taxa de fiscalização e vigilância sanitária, instituída pelo art. 23 desta lei, só poderão ser exercidas pelos Estados, Distrito Federal e Municípios por delegação da ANVISA. Mesmo ante a amplitude e complexidade da competência da ANVISA, a cobrança da Taxa de Fiscalização de Vigilância Sanitária encontra conforto na regra do art. 78 do CTN. Art. 78. Considera-se poder de polícia atividade da administração pública que, limitando ou disciplinando direito, interesse ou liberdade, regula a prática de ato ou abstenção de fato, em razão de interesse público concernente à segurança, à higiene, à ordem, aos costumes, à disciplina da produção e do mercado, ao exercício de atividades econômicas dependentes de concessão ou autorização do Poder Público, à tranquilidade pública ou ao respeito à propriedade e aos direitos individuais ou coletivos. Parágrafo único. Considera-se regular o exercício do poder de polícia quando desempenhado pelo órgão competente nos limites da lei aplicável, com observância do processo legal e, tratando-se de atividade que a lei tenha como discricionária, sem abuso ou desvio de poder. Nesse sentido já decidiu este Tribunal Regional Federal da 4aㅡ Região: TRIBUTÁRIO. TAXA DE FISCALIZAÇÃO DE VIGILÂNCIA SANITÁRIA. LEI N. 9.782/99. FATO GERADOR. ENQUADRAMENTO FISCAL. 1. O fato gerador da taxa de vigilância sanitária é o exercício do poder de polícia. 2. O faturamento é 
considerado pelo Poder Público apenas para efeito de enquadramento fiscal porquanto é necessário se estabelecer o porte da empresa. 3. A graduação segundo a capacidade econômica do contribuinte prevista no texto constitucional diz com impostos, espécie de tributo não vinculado, não se estendendo à taxa, espécie tributária estritamente vinculada ao exercício do Poder de Polícia. 4. Apelação improvida (AC 2001.7200007398-1, 1a Turma, Rel. Des. Álvaro Eduardo Junqueira, DJ 21/05/2008) TAXA DE FISCALIZAÇÃO DE VIGILÂNCIA SANITÁRIA. LEI N. 9.782/1999. ANVISA. VALOR FIXO. EQUIVALÊNCIA COM O CUSTO DA ATIVIDADE ESTATAL. LEGALIDADE. BITRIBUTAÇÃO. INOCORRÊNCIA. PRECEDENTES. 1. A Taxa de Fiscalização de Vigilância Sanitária, instituída pela Lei n. 9.782/99, tem como fato gerador atividade administrativa relacionada ao exercício do poder de polícia legalmente atribuído à ANVISA, no sentido de inibir-se a possibilidade de que surja qualquer risco sanitário à população brasileira. 2. "... 1. O fato gerador da taxa de vigilância sanitária, consoante a sua matriz jurídica, Lei $n$. 9.782/99, é o exercício do poder de polícia. (...) (AMS 2000.72.00.004234-7, Rel. Juiz Federal Marcos Roberto Araújo dos Santos, D.E. 19/02/2008). 3. “... 2. O faturamento da empresa foi utilizado somente para efeito de enquadramento do seu tipo empresarial, como referência para fixação do quantum devido a título de taxa de fiscalização sanitária, o qual varia conforme o porte da empresa e o grau de atividade sujeita à fiscalização e vigilância sanitária. (...) (AMS 2001.04.01.064986-8, Rel. Des. Fed. Joel Ilan Paciornick, D.E. 04/03/2008). 4. Ao decidir pela constitucionalidade da taxa de fiscalização da Comissão de Valores Mobiliários - CVM, a Corte Suprema admitiu a cobrança de valor fixo (RE 177.835, Rel. Min. Carlos Velloso, 2001). 5. A equivalência com o custo da atividade estatal foi estimada pelo legislador, não havendo indício de que estejam dissociados dos gastos suportados pelo erário para manter a estrutura de fiscalização e a realização das atividades inerentes à concessão da autorização, e deve ser suportado por quem da causa e se beneficie diretamente desta atividade. 6. Não há bitributação pelo fato de o sujeito passivo estar submetido à fiscalização sanitária por mais de um ente estatal, haja vista que cada ente cobra uma taxa pela atividade fiscalizatória que exerce, conforme a competência que Ihe cabe, definida em Lei. (APELAÇÃO CíVEL N. 0029232-07.2007.404.7100/ RS, Rel. Des. Federal OTÁVIO ROBERTO PAMPLONA, $2^{a}$ Turma, DJ 21/09/ 2010) Outrossim, inexiste bis in idem entre a taxa de licenciamento estadual e a referida Taxa de Fiscalização e Vigilância Sanitária, conforme se verifica no precedente do E. STJ: TRIBUTÁRIO. TAXA DISTRITAL DE VIGILÂNCIA SANITÁRIA. BITRIBUTAÇÃO. NÃO OCORRÊNCIA. COMPROVAÇÃO DE EFETIVA FISCALIZAÇÃO. DESNECESSIDADE. 1. Hipótese em que a recorrente argumenta ser inválida a taxa distrital de vigilância sanitária. Alega: a) bitributação em relação à taxa cobrada pela União e b) cobrança do tributo sem comprovação de efetiva fiscalização. 2. À luz do art. 145, II, da CF, a competência tributária para instituir taxa de poder de polícia decorre da 
competência material para realizar a fiscalização. 3. Havendo duas esferas estatais (União e Distrito Federal) que exercem a fiscalização sanitária, é de reconhecer, analogamente, duas áreas de competência tributária distintas. Dito de outra forma, não há falar em bitributação, pois os fatos geradores e as respectivas competências tributárias não se confundem ou se anulam. 4. Isso porque a fiscalização sanitária é competência comum da União, Estados e Municípios no âmbito do Sistema Único de Saúde, conforme o art. 200, II, da CF. 5. A execução das ações de vigilância sanitária compete, preponderantemente, aos Estados e aos Municípios, o que implica inafastável competência material do Distrito Federal, conforme os arts. 17 e 18 da Lei do SUS (Lei n. 8.080/1990). Disso deflui necessariamente a competência tributária para instituir a taxa de fiscalização correspondente. 6. A jurisprudência atual do STF e do STJ reconhece que a notoriedade da fiscalização realizada pelas autoridades públicas afasta a necessidade de comprovação do efetivo exercício de poder de polícia. Por essa razão, foi cancelada a Súmula 157/ STJ. 7. Recurso Ordinário não provido. (RMS 21752/DF, Rel. Ministro Herman Benjamin, Segunda Turma, unânime, Dje 20/08/2009) Por todo exposto, o exercício da atividade de vigilância sanitária requer fiscalização constante, de modo a reconhecer como legítima a cobrança da Taxa de Fiscalização de Vigilância Sanitária (TFVS) e suas renovações devidas pelas empresas que desempenhem atividades sujeitas ao controle e fiscalização sanitária, conforme previsto na Lei n. 9.782/99. Assim, entendo ser legítima a cobrança da TFVS e da taxa de renovação. Honorários: Reformada a sentença, cabível a inversão da sucumbência. É entendimento desta Turma os honorários de advogado devem ser fixados em $10 \%$ sobre o valor da causa ou da condenação, afastando-se desse critério somente quando tal valor for exorbitante ou quando restar muito aquém daquilo que efetivamente deveria receber o advogado, nos termos do art. 20, § $4^{\circ}$, do CPC, levando em conta as alíneas do $\S$ 3으 do mesmo dispositivo legal, a serem corrigidos pelo IPCAE. Assim, fixo a verba honorária em favor da União no percentual de $10 \%$ sobre o valor atualizado da causa. Dispositivo: Em face do exposto, nos termos do art. 557, $\S 1^{\circ}-\mathrm{A}$, do CPC, dou provimento ao recurso de apelação e ao agravo retido. Publique-se. Intimem-se.

Tribunal Regional Federal 4 $4^{\mathrm{a}}$ Região

Processo: AC - APELAÇÃO CIVEL 2007.72.00013721-3/SC

Relator: Álvaro Eduardo Junqueira

Órgão Julgador: PRIMEIRA TURMA

Julgamento: 5.4.11

MEIOS DE CONTROLE EM DIREITO SANITÁRIO. EXERCÍCIO PROFISSIONAL. ACUPUNTURA. 1. O fato de não haver lei em sentido estrito definindo o conceito de ato médico no Brasil e enquadrando a prática de acupuntura como tal não é suficiente para que seja alcançada a conclusão de que essa prática não é atividade médica exclusiva e, portanto, estaria ao 
livre alcance de outros profissionais da área de saúde. 2. A prática da acupuntura, que é ramo da medicina tradicional chinesa, o qual, na própria China, conforme demonstra o documento de fls. 129/130 é atividade médica privativa, engloba o diagnóstico nosológico (avaliação explicativa das queixas do paciente sob o aspecto patológico) e a indicação do tratamento adequado do ponto de vista da terapêutica alternativa vinculada aos conhecimentos desse ramo médico tradicional chinês. 3. Não há, portanto, em face desse quadro estrutural da prática em questão como deixar de entender a prática da acupuntura como prática médica e, portanto, sujeita à tutela dos órgãos de fiscalização profissional médicos e ao exercício exclusivo por médicos reconhecidos por estes. 4. Não provimento ao agravo de instrumento.

Tribunal Regional Federal - 5 ${ }^{\text {a }}$ Região

Processo: 0002072-95.2011.4.05.0000 - Classe: AGTR - Agravo de Instrumento

Relator: Emiliano Zapata Leitão

Órgão Julgador: Primeira Turma

Julgamento: 17.3 .11

DIREITO PÚBLICO DA SAÚDE. FORNECIMENTO DE TRATAMENTO. PRÓTESE. 1. Decisão do $\mathrm{mm}$. juízo a quo que indeferiu pedido liminar de realização de procedimento cirúrgico não fornecido pelo SUS. 2. A agravante é portadora de coxartrose grave nos quadris (cid10 $\mathrm{m} 16$ ) devido a artrite reumatoide de evolução grave, e por isso necessita de procedimento cirúrgico nomeado "artroplasia total de quadril". 3. A prótese de cerâmica, não fornecida pelo SUS, é a indicada pelos médicos, posto que sua não utilização implicaria a necessidade de mais duas intervenções cirúrgicas na paciente. 4. É dever - constitucionalmente garantido - do estado garantir a saúde e a vida. Não restou, outrossim, comprovada limitação orçamentária que impossibilite a realização da cirurgia. 5. Agravo de instrumento a que se dá provimento. Prejudicado o agravo regimental.

Tribunal Regional Federal $-5^{\text {a }}$ Região

Processo: 0017569-86.2010.4.05.0000 - Classe: AGTR - Agravo de Instrumento

Relator: Paulo Gadelha

Órgão Julgador: Segunda Turma

Julgamento: 15.3.11

DIREITO SANITÁRIO CONSUMERISTA. PROCESSUAL.Trata-se de Agravo de Instrumento interposto por Sônia Tudesco de Almeida, contra a r. decisão de fl. 58 TJ, proferida pelo MM. Juiz de Direito da 8avara cível da Comarca de Juiz de Fora que, nos autos da ação de obrigação de fazer cumulada com indenização por danos morais, por ela proposta contra UNIMED Belo Horizonte Cooperativa de Trabalho Médico Ltda., indeferiu o pedido de antecipação de tutela, aduzindo estarem "ausentes os requisitos legais a respaldar a concessão da medida, notadamente o periculum in mora". Alega 
a autora/recorrente, em síntese, que a r. decisão hostilizada não merece prosperar, uma vez que seus efeitos causarão grave lesão ao seu direito. Pugna pelo provimento do recurso, com a concessão do efeito suspensivo ativo, para determinar "que a agravada, em um prazo máximo de 24 horas, autorize e cubra (...) a prótese cardíaca stent implantada na agravante." Presentes os pressupostos de admissibilidade, conheço do agravo. Para a concessão de efeito suspensivo, necessário que demonstre a agravante a possibilidade de que a r. decisão agravada possa lhe causar dano grave e de difícil reparação, devendo ainda haver relevante fundamentação jurídica para tal, requisitos que não vislumbro no presente recurso. É que em análise superficial dos autos não verifico desacerto da decisão agravada. Importante salientar que não há neste momento questionar a gravidade do estado da agravante. Assim como decidiu o MM. Juiz, também entendo estar ausente o periculum in mora, "considerando que já houve a implantação do stent na suplicante que, inclusive, já recebeu alta médica no dia 18.03.2011". Neste sentido, já decidiu este E. Tribunal: EMENTA: AGRAVO DE INSTRUMENTO - TUTELA ANTECIPADA EM SEDE RECURSAL - EFEITO ATIVO EXIGÊNCIA DOS REQUISITOS DO ART. 273 DO CÓDIGO DE PROCESSO CIVIL - PLANO DE SAÚDE — TRATAMENTO HOME CARE — NEGATIVA - EXISTÊNCIA DE CLÁUSULAS LIMITATIVAS E PROIBITIVAS POSSIBILIDADE - VOTO VENCIDO. Nos termos do art. 527, III, do Código de Processo Civil, o relator poderá conceder a tutela antecipada em sede recursal. Em outras palavras, quando a decisão recorrida tiver conteúdo negativo, pode ser deferida a medida pleiteada em primeiro grau. Está-se diante do chamado efeito ativo. Os contratos de adesão são permitidos em lei, com possibilidade, inclusive, de limitação de alguns direitos do consumidor. Todavia, ressalta-se que, além da exigência legal de que as cláusulas sejam destacadas para imediata e clara compreensão, não são todos os direitos que podem ser limitados. (TJMG. AGRAVO N. 1.0024.07.666313-7/001 — RELATOR: EXMO. SR. DES. MARCELO RODRIGUES. Data da Publicação: 15/12/2007). Assim, num juízo de conhecimento prefacial, não há deferir a antecipação de tutela pretendida pela recorrente. Mediante tais considerações, com fulcro no art. 527, II, do CPC, converto o presente agravo em retido, por não vislumbrar lesão grave ou de difícil reparação. À Comarca de origem para apensamento aos autos principais. P. R. I. Belo Horizonte, 05 de abril de 2011. Belo Horizonte, 06 de abril de 2011. DES ${ }^{a}$ SELMA MARQUES, Relatora.

Tribunal de Justiça de Minas Gerais

Processo: 0186307-45.2011.8.13.0000

Relator: Selma Marques

Julgamento: 6.4.11

DIREITO CIVIL DA SAÚDE. RESPONSABILIDADE. ERRO MÉDICO. A ação de reparação decorrente de suposto erro médico necessita de produção de 
prova da culpa do profissional. - A responsabilidade contratual médica não depende dos resultados, restringindo-se à necessidade de utilização de todos os meios disponíveis. - Comprovado nos autos que inexistiu imperícia, imprudência ou negligência no procedimento realizado, não se pode falar em indenização. RECURSO CONHECIDO E IMPROVIDO.

Tribunal de Justiça do Amazonas

Processo: 2010.005008-2 - Apelação Cível

Relator: Domingos Jorge Chalub Pereira

Órgao Julgador: Primeira Câmara Cível

Julgamento: 28.3.11

DIREITO PÚBLICO DA SAÚDE. PARTICIPAÇÃO DA COMUNIDADE. CONSELHO DA SAÚDE. Evidente violação ao direito líquido e certo dos impetrantes ante a ilegalidade do ato promovido pela autoridade coatora na destituição do conselho de saúde e nomeação de novos membros em detrimento dos que ocupavam os cargos anteriormente. Configuração da ocorrência do abuso de poder realizado pela autoridade coatora ao se esquivar em assinar o mandado de intimação, bem como ao descumprir determinação judicial. Manutenção integral da sentença guerreada pelos seus próprios fundamentos em sede de reexame de sentença. Recurso conhecido e improvido à unanimidade. Acórdão. Vistos, relatados e discutidos os autos. Acordam, os Excelentíssimos Desembargadores integrantes da Segunda Câmara Cível Isolada do Tribunal de Justiça do Estado, à unanimidade de votos, em CONHECER DO REEXAME DE SENTENÇA E APELAÇÃO CÍVEL, E NEGAR-LHES PROVIMENTO, nos termos do voto do Relator. Custas na forma da lei. Este julgamento foi presidido pelo Exmª Des ${ }^{\underline{a}}$ Helena Percila de Azevedo Dornelles. Belém(PA), 4 de abril de 2011. Desembargador CLÁUDIO A. MONTALVÃO NEVES, Relator.

Tribunal de Justiça do Pará

Processo: REEXAME NECESSÁRIO/APELAÇÃO CÍVEL: 2009.3014013-8 Relator: Cláudio A. Montalvão Neves

Julgamento: 4.4 .11

DIREITO PÚBLICO DA SAÚDE. FORNECIMENTO DE EQUIPAMENTO. Portador de doença degenerativa. Troca de equipamento hospitalar necessário a tratamento domiciliar. Pessoa hipossuficiente. Liminar concedida. Necessidade e urgência do pleito. Garantia constitucional. Concessão da segurança. É dever do Estado fornecer equipamento necessário a tratamento domiciliar de Paciente portador de doença neurodegenerativa progressiva. Vistos, relatados e discutidos estes autos do Mandado de Segurança n. 0501319-93.2010.8.01.0000, de Rio Branco, em que figuram como partes as supranominadas, ACORDA, à unanimidade, o Tribunal Pleno do Egrégio Tribunal de Justiça do Estado do Acre, em 
conceder a segurança, tudo nos termos do voto do Relator e notas taquigráficas arquivadas. Rio Branco, 13 de abril de 2011.

Tribunal de Justiça do Acre

Processo: 0501319-93.2010.8.01.0000 — Mandado de Segurança / Saúde

Órgão julgador: Tribunal Pleno

Relator: Francisco das Chagas Praça

Julgamento: 13.4.11

DIREITO CIVIL DA SAÚDE. RESPONSABILIDADE. ERRO MÉDICO. Tutela antecipada concedida. Preliminares: não conhecimento do recurso por perda de objeto - rejeição; ilegitimidade passiva ad causam - não conhecimento. Mérito: alegação de ausência dos requisitos para concessão da tutela descabimento; plano de saúde e patologia grave incontroversos - perfuração do septo nasal; situação de urgência comprovada; necessidade de cirurgia com profissional especializado de outra localidade - ausência de profissional habilitado na rede cooperada. Presença dos requisitos do art. 273 do Código de Processo Civil. Custeio de passagens e hospedagem da usuária para realização do procedimento: impossibilidade - ausência de previsão contratual. Recurso parcialmente provido.

Tribunal de Justiça do Mato Grosso

Processo: AGRAVO DE INSTRUMENTO N. 2364/2011 — CLASSE CNJ $-202$

Relatora: Marilsen Andrade Addario

Órgão Julgador: SEGUNDA CÂMARA CÍVEL

Julgamento: 30.3 .11

DIREITO SANITÁRIO CONSUMERISTA. PLANO DE SAÚDE. USO DE MATERIAL IMPORTADO. 1. Conforme entendimento do Superior Tribunal de Justiça, mesmo sendo aparentemente válida a cláusula que veda o fornecimento de material importado para uso em cirurgia, não pode ela ser aplicada no caso concreto se o contrato de plano de saúde prevê a cobertura do ato cirúrgico ao qual aquele produto está ligado e se a sua utilização foi recomendada pelo médico assistente como necessário ao êxito do procedimento cirúrgico. 2. Restando demonstrado nos autos que a cirurgia recomendada pelo profissional de saúde é essencial para solucionar o grave problema de saúde da agravada e que a demora em sua realização poderá Ihe acarretar sequelas irreversíveis, é de ser concedida a tutela antecipada para autorizar o fornecimento dos materiais necessários ao sucesso do ato cirúrgico, sejam eles importados ou não. 3. Inexistindo obrigação legal para a fixação de caução como condição para a concessão de tutela antecipada, cabe ao magistrado singular aferir a sua necessidade de acordo com as peculiaridades do caso concreto e considerando que "a exigência da irreversibilidade inserta no $\S 2^{\circ}$ do art. 273 do CPC não pode ser levada ao 
extremo, sob pena de o novel instituto da tutela antecipatória não cumprir a excelsa missão a que se destina". (STJ-REsp n. 144.656-ES).

Tribunal de Justiça do Mato Grosso

Processo: AGRAVO DE INSTRUMENTO N. 98556/2010 — CLASSE $\mathrm{CNJ}-202$

Órgão Julgador: SEXTA CÂMARA CÍVEL

Relator: José Ferreira Leite

Julgamento: 23.3.11

DIREITO PÚBLICO DA SAÚDE. OBRIGAÇÃO DO ESTADO EM ARCAR COM PAGAMENTO DE INTERNAÇÃO EM UTI DE HOSPITAL PARTICULAR. Insuficiência de vagas na rede pública de saúde. Dano irreparável ou de difícil reparação. Situação emergencial: preterição dos trâmites administrativos. É inviável o julgamento do recurso pelo art. 557, do CPC, se os autos envolvem questão fática que ainda precisa ser decidida pelo Juízo a quo. Os documentos citados na decisão recorrida e que fundamentaram o deferimento da tutela antecipada são úteis para a correta compreensão do pedido recursal, incumbindo ao agravante juntá-los ao agravo, conforme dispõe o art. 525, II, do CPC. Comprovado pela decisão recorrida que havia urgência na internação do autor em leito de UTI face ao quadro de dengue hemorrágica grave, bem como que inexistiam vagas na rede pública, mostra-se correto o deferimento da tutela antecipada para que o Estado arque com o pagamento das despesas em hospital particular, havendo justificativas plausíveis para que os trâmites administrativos fossem adotados apenas posteriormente. É cabível a fixação da astreintes contra o Poder Público para assegurar que o mesmo cumpra a obrigação específica fixada por decisão judicial, nos termos do art. 461, §§ $4^{\circ}$ e 5으, do CPC.

Tribunal de Justiça do Mato Grosso

Processo: AGRAVO DE INSTRUMENTO N. 38649/2010 - CLASSE

$\mathrm{CNJ}-202$

Órgão Julgador: QUARTA CÂMARA CÍVEL

Relator: Antônio Horacio da Silva Neto

Julgamento: 22.3.11

DIREITO PÚBLICO DA SAÚDE. FEDERALISMO. FORNECIMENTO DE MEDICAMENTOS. 1. O Sistema Único de Saúde é composto pela União, Estados e Municípios, havendo responsabilidade solidária, entre os entes federativos, nas demandas que objetivam realizações de cirurgias, custeios de tratamentos médicos, bem como fornecimento de medicamentos. 2. Por se tratar de responsabilidade solidária entre os entes federativos, deve ser reconhecida a legitimidade de qualquer deles para figurar no polo passivo da demanda, cabendo ao autor a escolha do demandado, não havendo, assim, que se falar em litisconsórcio passivo necessário, mas sim, em hipótese de litisconsórcio passivo facultativo. 3. Restando demonstrada a desnecessidade de citação da União para integrar o polo passivo, não há que se falar em 
competência da Justiça Federal para a causa. 4. Nos casos em que o Parquet busca o fornecimento de medicamento, em favor de substituído, para tratamento de tumor cerebral, ou seja, situação cujo bem da vida tutelado é o direito à saúde, e até mesmo o próprio direito à vida do substituído, resta caracterizada a legitimidade ativa ad causam, uma vez que ao Ministério Público é atribuída a defesa dos direitos individuais indisponíveis. 5. A apresentação de documentos comprobatórios da enfermidade, bem como da necessidade de utilização do medicamento vindicado, tais como receituário, laudos de exames e relatórios médicos, são suficientes para caracterizarem a prova pré-constituída, sendo desnecessária qualquer dilação probatória. 6 . O direito constitucional à saúde, que se concretiza com o fornecimento de medicamentos pelo Estado, não pode ser obstaculizado em razão de mera formalidade administrativa, qual seja, a necessidade de inclusão do medicamento em lista elaborada pelo Ministério da Saúde. 7. Não cabe ao Demandante provar a inexistência de tratamento alternativo fornecido pelo SUS. Caso contrário, estaria o Poder Judiciário a exigir de todas as pessoas que demandam por fornecimento de medicamentos, na maioria das vezes, pessoas que possuem baixo grau de instrução, conhecimento acerca de todos os medicamentos constantes nas listas elaboradas pelo Poder Executivo, para, assim, comprovar que nenhum desses possui eficácia suficiente para o tratamento da enfermidade. 8. O Princípio da Separação dos Poderes, previsto no art. $2^{\circ}$ da Constituição Federal, se apresenta como um sistema de freios e contrapesos, estabelecendo uma repartição equilibrada de poderes, visando impedir que qualquer deles ultrapasse seus limites, ou seja, visa coibir o abuso e o arbítrio de qualquer dos poderes da República. 9. A omissão do Impetrado em fornecer o medicamento vindicado pelo substituído se afigura como um abuso do Poder Executivo, suficiente a autorizar a atuação do Poder Judiciário, uma vez que o direito à saúde, consagrado no art. 196, da Constituição Federal, é direito fundamental que integra o mínimo existencial, não podendo, sua concretização, ficar ao bel-prazer do administrador. 10. Como bem acentuou o Ministro Celso de Mello, "(...) a intervenção jurisdicional, justificada pela ocorrência de arbitrária recusa governamental em conferir significação real ao direito à saúde, tornar-se-á plenamente legítima (sem qualquer ofensa, portanto, ao postulado da separação de poderes), sempre que se impuser, nesse processo de ponderação de interesses e de valores em conflito, a necessidade de fazer prevalecer a decisão política fundamental que o legislador constituinte adotou em tema de respeito e de proteção ao direito à saúde". (STF, AgRg na SL n. 47, Rel. Min. Gilmar Mendes, Órgão Julgador: Tribunal Pleno, Julgamento: 17/03/2010. Pesquisa realizada no sítio www.stf.jus.br, em 08/03/2011) 11. A reserva do possível não se apresenta como óbice ao Poder Executivo em concretizar as ações de saúde, haja vista, o seu caráter integrador do mínimo existencial. 12. Embora venha o STF adotando a "Teoria da Reserva do Possível" em algumas hipóteses, em 
matéria de preservação dos direitos à vida e à saúde, aquela Corte não aplica tal entendimento, por considerar que ambos são bens máximos e impossíveis de ter sua proteção postergada. (STJ, REsp 784.241/RS, Rel. Ministra Eliana Calmom, Segunda Turma, julgado em 08/04/2008, DJe 23/ 04/2008. Pesquisa realizada no sítio www.stj.jus.br, em 08/03/2011) 13. “(..) a reserva do possível é matéria a ser alegada pelo Estado como defesa processual, cabendo-Ihe o ônus de provar suficientemente - e não simplesmente alegar de maneira genérica - a impossibilidade de atendimento das prestações demandadas." (V. Marcelo Novelino. Direito Constitucional, 2010. p. 475). Decisão: ACORDAM os componentes do Egrégio Tribunal Pleno do Tribunal de Justiça do Estado do Piauí, à unanimidade, em rejeitar as preliminares de alegação de litisconsorte passivo necessário e da consequente incompetência absoluta da Justiça Estadual para a causa, da ilegitimidade ativa do Ministério Público Estadual, da alegada necessidade de dilação probatória - inadequação da via eleita, da alegação de que o Estado não é obrigado a fornecer medicamento estranho à listagem do Ministério da Saúde e da necessidade de prova, pelo autor, da ausência de tratamentos fornecidos pelo SUS e da alegada violação ao princípio da separação dos poderes e da reserva do possível; no mérito, à unanimidade, conhecer do presente agravo regimental, eis que preenchidos os requisitos legais de admissibilidade, mas para negar-Ihe provimento, mantendo a decisão agravada em todos os seus termos, até final julgamento de mérito do mandado de segurança.

Tribunal de Justiça do Piauí

Processo: 201000010032602 — Mandado de Segurança

Órgão Julgador: Tribunal Pleno

Relator: Francisco Antônio Paes Landim Filho

Julgamento: 17.3.11

DIREITO SANITÁRIO CONSUMERISTA. PLANO DE SAÙDE. DANOS MATERIAIS E MORAIS. O Juiz é o destinatário da prova e a ele incumbe decidir sobre a necessidade ou não de sua produção. Assim sendo, convencendo-se o Magistrado da desnecessidade da produção de prova testemunhal, tem ele livre-arbítrio para indeferir a realização da prova que entende prescindível para a formação do seu convencimento, conforme dispõe o art. 130 do CPC. Aplicação do CDC e das normas contidas na nova Lei dos Planos de Saúde, uma vez que se trata de contrato com renovações sucessivas, de longa duração. Abusividade na recusa à cobertura contratual ao procedimento denominado angioplastia com colocação de "stents", material que sequer se constitui em prótese. Dano moral não configurado. $\mathrm{O}$ mero descumprimento contratual não dá ensejo ao reconhecimento da indenização de natureza subjetiva. AGRAVO RETIDO DESPROVIDO. PRELIMINAR REJEITADA. APELOS DESPROVIDOS. 
Tribunal de Justiça do Rio Grande do Sul

Processo: Apelação Cível N. 70035372960

Órgão Julgador: Quinta Câmara Cível

Relator: Romeu Marques Ribeiro Filho

Julgamento: 20.4.11

DIREITO PENAL SANITÁRIO. PRINCÍPIO DA INSIGNIFICÂNCIA INAPLICÁVEL. A infração tipificada no art. 28 da Lei de Drogas se caracteriza como de menor potencial ofensivo, comportando a aplicação de penas mais brandas, dentre as quais não se insere a privação de liberdade. Impossível desconsiderar, contudo, que o seu cometimento configura dano à saúde pública, bem jurídico tutelado, não se abrindo espaço, portanto, para a aplicação do Princípio da Insignificância ou para o reconhecimento da inconstitucionalidade do dispositivo legal, uma vez que não se insere na esfera de exercício da liberdade individual. RECURSO IMPROVIDO.

Tribunal de Justiça do Rio Grande do Sul

Processo: Recurso Crime N. 71002999639

Órgão Julgador: Turma Recursal Criminal

Relator: Luiz Antônio Alves Capra

Julgamento: 18.4.11

DIREITO SANITÁRIO CONSUMERISTA. PLANO DE SAÚDE. DESCREDENCIAMENTO DE CLíNICA. Aplicação do art. 17 da Lei n. 9.656/98, entendendo-se abrangido estabelecimento de tal natureza pelo conceito legal de "entidade hospitalar". Desligamento por parte da operadora que não foi, no caso, previamente comunicado à ANS e que, por implicar ao que tudo indica redução da rede referenciada, dependia, mais do que mera ciência, de autorização por parte da agência governamental controladora do setor. Direito da conveniada em seguir o tratamento quimioterápico perante a clínica na qual vinha sendo atendida reconhecido. Indenização por danos morais não devida, entretanto, em se tratando de divergência contratual derivada de interpretação ao menos razoável da lei. Demanda parcialmente procedente. Apelação da autora parcialmente provida.

Tribunal de Justiça de São Paulo

Processo: 0015189-39.2010.8.26.0011

Órgão julgador: $2^{\mathrm{a}}$ Câmara de Direito Privado

Relator: Fabio Tabosa

Julgamento: 19.4.11

DIREITO PÚBLICO DA SAÚDE. RESSARCIMENTO. SUS. SEGURO OBRIGATÓRIO (DPVAT). Despesas médicas decorrentes de acidente automobilístico. Reembolso que só tem lugar quando a vítima efetivamente arca com o pagamento das despesas médicas. Autora que é entidade conveniada ao SUS e deste recebe as verbas para o custeio do serviço 
médico prestado. Vítima que nada tinha a pagar. Cessão de direitos que não tem conteúdo, uma vez que a vítima não possuía direitos a ceder. Ausência de condenação. Honorários advocatícios que devem ser fixados com base no art. 20, § 4º, do CPC. Recurso da autora desprovido, provido o da ré.

Tribunal de Justiça de São Paulo

Processo: 0009953-23.2010.8.26.0362

Órgão julgador: 27ำ Câmara de Direito Privado

Relator: Dimas Rubens Fonseca

Julgamento: 19.4.11

DIREITO SANITÁRIO CONSUMERISTA. Ementa: BEM MÓVEL INDENIZATÓRIA — Ingestão de produto impróprio para consumo - Agravo retido desprovido - Fato do produto comprovado - Responsabilidade solidária do supermercado com o fabricante — Ocorrência de dano moral Arbitramento sob parâmetros de razoabilidade e proporcionalidade Correção monetária da sentença e juros da citação, para os danos morais Juros de mora contados do evento danoso. Súmula n. 54 do STJ - Ação procedente - Recurso desprovido

Tribunal de Justiça de São Paulo

Processo: 9197251-58.2009.8.26.0000

Órgão julgador: 35ª Câmara de Direito Privado

Relator: Melo Bueno

Julgamento: 18.4.11

DIREITO CIVIL DA SAÚDE. Ementa: RESPONSABILIDADE CIVIL. Infecção hospitalar. Município que acorda convênio com hospital e limita sua cooperação nos termos do acordo: ilegitimidade passiva ad causam confirmada. Inexistiu cerceamento de defesa: as provas documentais acostadas foram suficientes à formação do livre convencimento do juiz. Responsabilidade objetiva do hospital. Dever de indenizar. Ocorrência do dano moral; dano ...

RESPONSABILIDADE. INFECÇÃO HOSPITALAR Município que acorda convênio com hospital e limita sua cooperação nos termos do acordo: ilegitimidade passiva "ad causam" confirmada. Inexistiu cerceamento de defesa: as provas documentais acostadas foram suficientes à formação do livre convencimento do juiz. Responsabilidade objetiva do hospital. Dever de indenizar. Ocorrência do dano moral; dano estético não comprovado Indenização fixada com apreciação equitativa. Sucumbência recíproca. Concessão de justiça gratuita à Santa Casa, pois provada sua deficiente situação financeira. Afastadas as preliminares, recursos desprovidos.

Tribunal de Justiça de São Paulo

Processo: 0000526-17.2010.8.26.0066 
Órgão julgador: $11^{a}$ Câmara de Direito Público

Relator: Francisco Vicente Rossi

Julgamento: 18.4 .11

\begin{abstract}
ARGENTINA $^{(1)}$
DIREITO SANITÁRIO PREVIDENCIÁRIO. INDENIZAÇÃO. Riscos do trabalho. Corresponde a anular a decisão que confirmou a sentença de montante fixo de indenização por morte devido à doença contraída no momento do trabalho, estendendo-se a responsabilidade aos réus e os seguros de riscos de trabalho às empresas. Negou-se provimento ao pedido do autor por razões puramente formais. Deixou sem resposta o desafio específico, que foi baseado no princípio pro homine, em violação do direito à saúde, vida, integridade física e psicológica, a proteção integral da família, direitos de propriedade e reparação integral dos danos, e deixou a assinar uma declaração que estabelece um montante específico de avaliações de danos que não corresponde aos critérios delineados pelo Tribunal e que são geralmente tidos em conta os precedentes numerosos. O parecer da Procuradoria-Geral, encaminhado à Corte Suprema.
\end{abstract}

Corte Suprema de Justicia de la Nación

C. 1907. XLIII; RHE

Julgamento: 9.3.11

INDEMNIZACIÓN. RIESGOS DEL TRABAJO. Corresponde dejar sin efecto la sentencia que confirmó el monto de condena fijado en concepto de indemnización por muerte por la enfermedad contraída en ocasión de trabajo, extendiendo la responsabilidad a las empresas demandadas y a la aseguradora de riesgo del trabajo si al desestimar el planteo de la actora por razones meramente formales dejó sin respuesta la impugnación concreta que se apoyaba en el principio pro homine, en la afectación del derecho a la salud, a la vida, a la integridad psicofísica, la protección integral de la familia, en el derecho de propiedad y la reparación integral del daño, y dejó firme un pronunciamiento que con particulares apreciaciones fija un monto indemnizatorio que no se corresponde con los criterios delineados por la Corte y que son habitualmente tenidos en cuenta en numerosos precedentes. - Del dictamen de la Procuración General, al que remitió la Corte Suprema -.

Corte Suprema de Justicia de la Nación

C. 1907. XLIII; RHE

Fecha: 9.3.11

MEIOS DE CONTROLE EM DIREITO SANITÁRIO/DIREITO PENAL SANITÁRIO. MEDICAMENTOS. TRATAMENTO DE PESSOAS. SAÚDE PÚBLICA. COMPETÊNCIA FEDERAL. Se encontrarmos a instrução em curso, não se pode excluir que as pessoas empregadas pelo acusado e encontradas em uma casa em uma cidade interiorana, devido ao seu contexto de vulnerabilidade, podem encontrar-se em situações de exploração, nos termos

(1) Nota do editor: parte das decisões latino-americanas foram traduzidas em versões reduzidas. 
da Lei n. 26.364 e frente à existência de fatos que atentariam contra a saúde pública, a fabricação ilícita de insumos de uso medicinal, que são então distribuídos em nosocômios da Capital Federal, o que não descarta uma possível violação da Lei n. 16.463, ambos os fatos devem ser investigados pela justiça federal. O parecer da Procuradoria-Geral, encaminhado à Corte Suprema.

Corte Suprema de Justicia de la Nación

C. 519. XLVI; COM

Julgamento: 16.11 .10

TRATA DE PERSONAS. SALUD PÚBLICA. COMPETENCIA FEDERAL. Si hallándose la instrucción en trámite, surge que no es posible descartar que las personas empleadas por el imputado y halladas en una vivienda de una localidad provincial, debido a su contexto de vulnerabilidad, puedan encontrarse en situación de explotación - en los términos de la ley 26.364 - y frente a la existencia de hechos que atentarían contra la salud pública - elaboración ilegal de insumos de uso medicinal, que luego son distribuidos en nosocopios de la Capital Federal -, lo que no descarta una posible infracción a la ley 16.463, ambos hechos deben ser investigados por la justicia federal. - Del dictamen de la Procuración General, al que remitió la Corte Suprema -.

Corte Suprema de Justicia de la Nación

C. 519. XLVI; COM

Fecha: 16.11 .10

DIREITO SANITÁRIO CONSUMERISTA. DIREITO À SAÚDE. AMPARO. MENOR DEFICIENTE. COBERTURA INTEGRAL DO TRATAMENTO MÉDICO ASSISTENCIAL. Reembolso das despesas realizadas. Obrigação da empresa de medicina pré-paga. RECURSO DE APELAÇÃO. REJEIÇÃO. Prestação prevista na Lei n. 24.091. Atualização do Programa Médico Obrigatório. ESPECIAL DEFESA ESPECIAL DO DIREITO À SAÚDE E A VIDA DOS DEFICIENTES. SITUAÇÃO DE VULNERABILIDADE. Obrigação da justiça de implementar AÇÕES POSITIVAS considerando o art. 75, inc. 23 da Constituição Nacional. Direito à igualdade real de oportunidades. RELAÇÃO DE CONSUMO. Critério interpretativo "favor debitoris". Arts. 3 e 37 da Lei n. 24.240. Confirmação da sentença apelada.

Câmara de Apelações Civil e Comercial de Corrientes

Processo: $39937 / 4$

Sala IV

Julgamento: 3.11 .10

DERECHO A LA SALUD. AMPARO. Menor de edad DISCAPACITADA. COBERTURA INTEGRAL DEL TRATAMIENTO MÉDICO ASISTENCIAL. Reintegro de los gastos efectuados. OBLIGACIÓN A CARGO DE LA EMPRESA DE MEDICINA PREPAGA. RECURSO DE APELACIÓN. RECHAZO. Prestación contemplada en la ley 24.091. Actualización del Programa Médico Obligatorio. ESPECIAL RESGUARDO DEL DERECHO A LA SALUD Y A LA VIDA DE LAS PERSONAS DISCAPACITADAS. 
SITUACIÓN DE VULNERABILIDAD. Obligación a cargo de la justicia de emprender ACCIONES POSITIVAS en el marco del Art. 75 inc. 23 de la CN. Derecho a la igualdad real de oportunidades. RELACIÓN DE CONSUMO. Criterio interpretativo "favor debitoris." Arts. 3 y 37 de la ley 24.240. SE CONFIRMA LA SENTENCIA APELADA

CÁMARA DE APELACIONES EN LO CIVIL Y COMERCIAL DE CORRIENTES SALA IV

Expediente N. 39937/4

Fecha: 3.11 .10

\section{CHILE}

\section{DIREITO SANITÁRIO CONSUMERISTA}

Inaplicabilidade por inconstitucionalidade do art. 38 da Lei n. 18.993, na ação sobre recurso de proteção contra a Isapre Cruz Blanca S.A. que se encontra pendente ante a Corte de Apelações de Santiago. Nos termos do art. 93, inciso $1^{\circ}$, ns. $6^{\circ}$ e $11^{\circ}$ da Constituição da Política da República, na ação impetrada se requer a não aplicação do art. 38 da Lei n. 18.933 que trata das Instituições Sociais de Saúde, porque a sua aplicação ao caso contraria os direitos reconhecidos na Constituição; Na busca por dar eficácia ao que foi decidido na sentença de inconstitucionalidade e a fim de evitar qualquer possibilidade de que a norma legal objetada seja, eventualmente, aplicada por tribunais que conhecem a pendência e ao fazê-lo, ofendam a Constituição, o presente recurso de inaplicabilidade será acolhido. O ministro José Antonio Viera-Gallo Quesney que participou da sentença prevê o seguinte: 1. Que, dado o legislador negativo do Tribunal Constitucional, os acórdãos que institui a inconstitucionalidade de uma norma jurídica que institui um único efeito erga omnes e ex nunc ou pro futuro após a sua publicação no Jornal Oficial, sem afetar a consolidada por meio de contratos celebrados ao abrigo da regra que seja declarada inconstitucional; Que os processos judiciais que suscitaram antes da sentença do Tribunal de Justiça que declarou inconstitucional parte do art. 38 da Lei n. 18.933, sobre a aplicação dos contratos de saúde validamente celebrados antes dessa data, devem ser resolvidos nos termos da legislação em vigor antes da decisão de inconstitucionalidade do Poder Judiciário, Tribunal Constitucional, composta por seu Presidente e mais sete Ministros.

Tribunal Constitucional

Sentença: Rol 1811

Julgamento: 24.4 .11

Con fecha 26 de agosto de 2010, doña Tamara Sebastiana Meza Zúñiga ha deducido acción de inaplicabilidad por inconstitucionalidad del artículo 38 ter de la Ley n. 18.933, en la causa sobre recurso de protección en contra de la Isapre Cruz Blanca S.A., que se encuentra pendiente ante la Corte de Apelaciones de Santiago, bajo el Rol de ingreso $n$. 3839-2010. El caso es que la requirente suscribió con la mencionada Isapre 
un plan de salud el 10 de septiembre de 2009 (fojas 43) y, mediante carta de 30 de junio de 2010 (fojas 23), ésta le comunicó el aumento del precio base y el cambio en su tramo de edad (25 años) con la consiguiente variación de su factor de riesgo, por lo que el precio del plan aumentó de 1,44 a 2,09 Unidades de Fomento mensuales. Sostiene el actor que el artículo 38 ter, en su aplicación al caso concreto, resulta contrario a las garantías establecidas en el artículo 19 ns. $2^{\circ}$, 9․ $18^{\circ}, 24^{\circ}$ y $26^{\circ}$ de la Constitución, que se refieren, respectivamente, a la igualdad ante la ley, al derecho de protección de la salud, al derecho a la seguridad social, al derecho de propiedad y a la garantía del contenido esencial de los derechos fundamentales.Señala, al efecto, que al autorizarse a las Isapres para ajustar los precios de los contratos de salud en relación con la edad y el sexo de los beneficiarios, la norma legal impugnada establece una diferencia entre los distintos grupos etarios y entre hombres y mujeres, de modo que, para acceder al mismo beneficio, unos deben pagar más que otros. Esta diferencia, señala el requirente, es arbitraria, porque la edad y sexo son hechos involuntarios, a diferencia de otros que involucran una exposición voluntaria al riesgo, como los hábitos de fumar o beber en exceso. Además, señala, sería erróneo pensar que el aumento de edad vaya necesariamente aparejado a una mayor ocurrencia de enfermedades. En fin, que la norma legal impugnada sería arbitraria en un sentido ético, por atentar contra la justicia. Agrega que el precepto legal cuestionado supone un cortapisa a la libertad de las personas para elegir y permanecer en el plan de salud por el que optaron al celebrar el contrato, siendo el fuerte y creciente aumento del precio una forma indirecta de obligarlas a salir del sistema privado, vulnerando así la garantía del libre e igualitario acceso a la protección de la salud y el derecho a elegir el sistema al que la persona desee acogerse, sea estatal o privado. Señala que además se estaría vulnerando el derecho a la seguridad social en medida que éste está íntimamente vinculado tanto con la protección de la salud como con la dignidad de la persona humana. En ese sentido, afirma, las Isapres, al estar facultadas para intervenir en la satisfacción del derecho a la protección de la salud de sus afiliados, deben procurar que los derechos consustanciales a la dignidad humana no sean afectados en su esencia ni menoscabados por la imposición de condiciones o requisitos que hagan imposible su libre ejercicio. En ese sentido, agrega, la obligación de los particulares de respetar y promover los derechos inherentes a la dignidad de las personas persiste incluso en las relaciones convencionales entre privados. Por ello, sostiene, un alza de precio del plan de salud que por su costo obliga a los afiliados a emigrar del sistema privado de salud, constituye un atropello ilegítimo e inconstitucional. Repara que se infringe, además, el derecho de propiedad de la actora, pues al exigirse una mayor cotización para mantener los mismos beneficios, junto con impedirle su derecho a hacer uso del sistema privado de salud así como de los beneficios que éste otorga, bienes que ya se encuentran incorporados a su patrimonio, se le estaría privando, además, injustamente de parte de dicho patrimonio, al no haber una contraprestación equiparable al aumento del precio. Observa que las tablas de factores que contempla el precepto legal impugnado impone como condición, requisito o tributo el aumento de la cotización mensual para permanecer en el sistema privado de salud y en el plan elegido, afectando así la esencia de las garantías constitucionales a que se ha aludido. Por resolución de 8 de septiembre de 2010 (fojas 31) la Primera Sala de este Tribunal admitió a trámite el requerimiento entablado y ordenó la suspensión del procedimiento en que incide; posteriormente, por resolución de 10 de noviembre del mismo año (fojas 48), lo declaró admisible. Pasados los autos al Pleno para su sustanciación, el 
requerimiento fue puesto en conocimiento de los órganos constitucionales interesados y de la Isapre Cruz Blanca S.A., sin que ésta formulara observaciones sobre el fondo dentro del plazo legal. Se ordenó traer los autos en relación y, en audiencia de fecha 25 de enero de 2011, se procedió a la vista de la causa conjuntamente con las causas roles 1697-2010 y 1822-2010. CONSIDERANDO: PRIMERO: Que, conforme con el artículo 93, incisos primero, n. 6ㅜ y undécimo de la Constitución Política de la República, según se señala en la parte expositiva de esta sentencia, en la acción deducida en autos se solicita inaplicar - en lo pertinente - el artículo 38 ter de la Ley n. 18.933, sobre Instituciones de Salud Previsional, porque su aplicación al caso específico de que se trata, resultaría contraria a los reseñados derechos reconocidos por la Constitución; SEGUNDO: Que, por sentencia de 6 de agosto de 2010 (Rol 1710), expedida con arreglo al artículo 93, incisos primero, $n$. $7^{\circ}$, y duodécimo de la Constitución, este Tribunal ya se pronunció sobre la materia, declarando inconstitucionales los números 1, 2, 3 y 4 del inciso tercero del referido precepto legal, precisamente por contravenir la Carta Fundamental; TERCERO: Que, por ende, a partir de la publicación del aludido fallo en el Diario Oficial, ocurrida el 9 de agosto de 2010, las reglas sobre alzas que preveían los ns. 1 al 4 del inciso tercero del cuestionado artículo 38 ter, correspondiente al artículo 199 del Decreto con Fuerza de Ley n. 1, de 2005, del Ministerio de Salud, perdieron validez general, de modo que no pueden seguir aplicándose, tal como razonó esta Magistratura en ese mismo veredicto (considerandos $169^{\circ}$ al $171^{\circ}$ ) y en su posterior sentencia recaída en los autos $R o l$ 1552-2009; CUARTO: Que, así las cosas, en procura de hacer eficaz lo resuelto en la mencionada sentencia de inconstitucionalidad y a fin de evitar cualquier posibilidad de que la norma legal objetada pueda, eventualmente, aplicarse por los tribunales que conocen de la gestión pendiente y que, al hacerlo, se vulnere la Constitución, el presente recurso de inaplicabilidad será acogido. Y TENIENDO, ADEMÁS, PRESENTE lo prescrito en los artículos $6^{\circ}$ y $7^{\circ}$ de la Carta Fundamental, así como las disposiciones pertinentes de la Ley Orgánica Constitucional del Tribunal Constitucional, SE RESUELVE: QUE SE ACOGE EL REQUERIMIENTO DE INAPLICABILIDAD DEDUCIDO A FOJAS UNO. Se deja sin efecto la suspensión del procedimiento decretada a fojas 31. Ofíciese al efecto a la Corte de Apelaciones de Santiago. El Ministro señor José Antonio Viera-Gallo Quesney concurre al fallo con la siguiente prevención: $1^{\circ}$ Que, dado el carácter de legislador negativo del Tribunal Constitucional, las sentencias que establecen la inconstitucionalidad de un precepto legal sólo producen efectos constitutivos erga omnes y ex nunc o pro futuro a partir de su publicación en el Diario Oficial, sin afectar situaciones consolidadas mediante contratos celebrados al amparo de la norma cuya inconstitucionalidad se declara; $2^{\circ}$ Que el tema de los efectos de tales sentencias en el tiempo fue ampliamente debatido durante la reforma a la Constitución efectuada el año 2005, cuando se introdujo la facultad contenida en el actual artículo 93 n. $7^{\circ}$ de la Constitución. En dicha ocasión, a sugerencia del Ministro Eugenio Valenzuela, se alcanzó consenso respecto a la necesidad de evitar incertidumbres del todo inconvenientes para el ordenamiento jurídico, especialmente en materia civil. Como consta en la historia fidedigna de dicha reforma, se estimó conveniente dejar expresa constancia en relación a que los fallos del Tribunal Constitucional que declaran inconstitucional un precepto legal producen efectos desde su publicación en el Diario Oficial y, en caso alguno, tienen efecto retroactivo (Segundo Informe de la Comisión de Constitución, Legislación, Justicia y Reglamento del Senado, Boletines ns. 2.526-07 y 2.534-07, p. 278); 3ํ Que lo anterior 
fue reforzado por el veto enviado por el Ejecutivo, el cual estableció que "no obstante, el precepto declarado inconstitucional en conformidad a lo dispuesto en los numerales 2, 4 ó 7 del artículo 93, se entenderá derogado desde la publicación en el Diario Oficial de la sentencia que acoja el reclamo, la que no producirá efecto retroactivo", no dejando lugar a dudas sobre los alcances exclusivamente prospectivos de tales sentencias; $4^{\circ}$ Que, al efecto, se tuvo en consideración el ejemplo de otros países, como Italia, donde impera el principio de irretroactividad de las sentencias de inconstitucionalidad, sin que se vea lesionada o menoscabada la supremacía constitucional; $5^{\circ}$ Que, en consecuencia, una declaración de inconstitucionalidad por parte de esta Magistratura no puede afectar los derechos legalmente constituidos ni las situaciones consolidadas mediante contratos celebrados con anterioridad, tal como lo sostiene la Ley sobre Efecto Retroactivo de las Leyes; 6ำ Que, por tanto, los procesos judiciales que se suscitaron antes de la sentencia de este Tribunal que declaró inconstitucional parte del artículo 38 ter de la Ley n. 18.933, sobre la aplicación de los contratos de salud válidamente celebrados con antelación a esa fecha, deben ser resueltos conforme a las disposiciones legales vigentes con anterioridad a la sentencia de inconstitucionalidad de esta Magistratura; $7^{\circ}$ Que, por ende, corresponde acoger el presente recurso de inaplicabilidad por las razones de fondo que esta Magistratura ha señalado en numerosas oportunidades, pues, efectivamente, la posible aplicación del artículo 38 ter de la Ley n. 18.933, actual artículo 199 del DFL n. 1, del Ministerio de Salud, de 2005, en el caso en cuestión provocaría efectos contrarios a la Constitución. Redactaron la sentencia los Ministros que la suscriben y la prevención su autor. Notifíquese, regístrese y archívese. Pronunciada por el Excmo. Tribunal Constitucional, integrado por su Presidente, Ministro señor Marcelo Venegas Palacios, y por los Ministros señor Raúl Bertelsen Repetto, señora Marisol Peña Torres y señores Francisco Fernández Fredes, Carlos Carmona Santander, José Antonio Viera-Gallo Quesney, Iván Aróstica Maldonado y el Suplente de Ministro señor Ricardo Israel Zipper. Autoriza la Secretaria del Tribunal, señora Marta de la Fuente Olguín.

Tribunal Constitucional

Sentencia Rol 1811

Fecha: 24.4.11

Os requerentes expressamente assinalam que a eventual inconstitucionalidade das aludidas glosas se fundamenta no fato de que elas foram incorporadas ao projeto de lei em questão, no primeiro trâmite constitucional, por indicações dos deputados (mencionados) e não por meio da forma prevista na Lei Fundamental, violando desta forma, a iniciativa legislativa exclusiva do Presidente da República e excedendo-se à ideia principal do projeto de lei, sendo ambas questões reguladas constitucionalmente. 09. A Pesquisa Nacional Urbana de Segurança Pública (ENUSC), a ser realizada anualmente pelo Instituto Nacional de Estatísticas (INE). A distribuição dos fundos de segurança pública para os municípios, vai considerar o nível de vitimização, exibida por estas comunidades na Pesquisa Nacional Urbana de Segurança Pública realizada pelo (INE) no ano anterior. 05. O mais tardar em 31 de março de 2011 a Subsecretaria da Fazenda deverá informar à Comissão Especial Mista do Orçamento sobre as linhas de ação desenvolvidas, o cronograma de implantação e os aspectos técnicos gerais, que estão dentro do âmbito das 
suas competências, relacionadas com o cumprimento do compromisso presidencial para estender a licença-maternidade para seis meses pós-parto. 06. O mais tardar em 31 de março de 2011 a Subsecretaria da Fazenda deverá informar à Comissão Especial Mista do Orçamento sobre as linhas de ação desenvolvidas, o cronograma de implantação e os aspectos técnicos gerais, que estão dentro do âmbito das suas competências, relacionadas com o cumprimento do compromisso presidencial de eliminar $7 \%$ das contribuições de saúde para os pensionistas no país. SE DECLARA: 1) Que aceita a solicitação, assim como se declara inconstitucional a glosa de número 09 da Partida 05 (Ministério do Interior), contida no projecto de Lei do Orçamento do Setor Público para o ano de 2011, que, portanto, deverá ser eliminado da Lei n. 20.481 - Lei do Orçamento do Sector Público para 2011 - publicado no Diário Oficial em sua edição de 18 de dezembro de 2010. 2) Que se rejeita 0 requerimento apresentado para as glosas 05 e 06 da Partida 08 (Ministério da Fazenda) do referido projeto de lei.

Tribunal Constitucional

Sentença: Rol 1867

Julgamento: 30.12 .10

Mediante presentación de fecha 30 de noviembre de 2010, complementada por la ingresada el día 7 de diciembre del mismo año, un grupo de 10 senadores, que representan más de la cuarta parte de los miembros en ejercicio de esa Corporación, han deducido ante esta Magistratura un requerimiento para que se declaren inconstitucionales "la Glosa 09, introducida por la Cámara de Diputados y aprobada por el Senado, mediante la indicación n. 8 a la Partida 05 (Ministerio del Interior), Capítulo 01, Programa 05 (Programa de Seguridad y Participación Ciudadana), denominada "Encuesta INE" y "las Glosas ns. 05 y 06, introducidas mediante indicación ns. 29 A y 29 B, respectivamente, en la Cámara y aprobadas por el Senado, a la Partida 08 (Ministerio de Hacienda), Capítulo 01, Programa 01; denominadas compromisos sobre ampliación del postnatal y eliminación de la cotización de salud del $7 \%$ de los pensionados", todas ellas contenidas en el proyecto de ley de Presupuestos del Sector Público para el año 2011 (Boletín 7226-05). La nómina de senadores requirentes es la siguiente: Jovino Novoa Vásquez (designado como representante), Andrés Chadwick Piñera, Juan Antonio Coloma Correa, José García Ruminot, Antonio Horvath Kiss, Hernán Larraín Fernández, Pablo Longueira Montes, Evelyn Matthei Fornet, Jaime Orpis Bouchon y Víctor Pérez Varela. A fojas 295 de los autos consta que el día 30 de noviembre de 2010 el Tribunal puso en conocimiento de S.E. el Presidente de la República la acción deducida. Las glosas cuya constitucionalidad se cuestiona en este proceso disponen: "09. La encuesta Nacional Urbana de Seguridad Ciudadana (ENUSC) que deberá realizarse anualmente por el Instituto Nacional de Estadísticas. La distribución de los fondos de seguridad ciudadana a las comunas, se hará en consideración al nivel de victimización exhibida por dicha comuna en la Encuesta Nacional Urbana de Seguridad Ciudadana realizada por el Instituto Nacional de Estadísticas (INE) en el año inmediatamente anterior." "05. A más tardar el 31 de marzo de 2011 la Subsecretaría de Hacienda deberá informar a la Comisión Especial Mixta de Presupuestos sobre las líneas de acción desarrolladas, el cronograma de implementación y aspectos técnicos generales, que estén dentro del marco de sus competencias, relacionados con el cumplimiento del compromiso presidencial de 
extender el descanso de maternidad hasta seis meses después del parto." "06. A más tardar el 31 de marzo de 2011 la Subsecretaría de Hacienda deberá informar a la Comisión Especial Mixta de Presupuestos sobre las líneas de acción desarrolladas, el cronograma de implementación y aspectos técnicos generales, que estén dentro del marco de sus competencias, relacionados con el cumplimiento del compromiso presidencial de eliminar el $7 \%$ de cotización de salud para los pensionados del país." Los requirentes expresamente señalan que la eventual inconstitucionalidad de las aludidas glosas se fundamenta en el hecho de que fueron incorporadas al proyecto de ley de que se trata, en el primer trámite constitucional, por indicaciones de los diputados que se mencionan y no por la vía idónea prevista en la Ley Fundamental, vulnerándose, de esta forma, la iniciativa legislativa exclusiva del Presidente de la República y excediéndose, además, la idea matriz del mismo proyecto de ley, ambas cuestiones reguladas constitucionalmente. Antes de entrar al fondo de la cuestión de constitucionalidad que se somete al conocimiento y resolución de este Tribunal, y como consideraciones de carácter general los requirentes se refieren en detalle a la tramitación legislativa de las reglas cuestionadas y a la oportunidad y forma en que diversos senadores formularon reserva de inconstitucionalidad a su respecto. Desarrollan también las características y principios básicos del régimen presupuestario indicando, en síntesis, que la Ley de Presupuestos sería una norma de carácter "temporal" y "sui generis" que tiene un contenido preciso y específico definido en la Constitución Política - en el artículo 67 - y en la Ley Orgánica Constitucional del Congreso Nacional. Se hace alusión, asimismo, al contenido del Mensaje con el que se inició la tramitación de este proyecto de ley, que contiene 24 artículos que, siguiendo las ideas matrices de esta clase de legislación, regulan el cálculo de ingresos y la autorización de gastos relativa a la ejecución del presupuesto y a la administración financiera del Estado. En este punto, recuerdan los requirentes que esta Magistratura Constitucional ha declarado que las expresadas constituyen las ideas matrices del proyecto de ley de Presupuestos del Sector Público, en su sentencia Rol 1005, de 2007 (considerando 12). Luego hacen hincapié en que como prioridades del correspondiente ejercicio presupuestario, el Mensaje definió las siguientes: a) Poner acento en el gasto social; b) Reforzar la seguridad ciudadana; c) Fortalecer a las regiones, $y$ d) Poner un especial énfasis en la inversión. Refiriéndose al deber de información que pesa sobre la Administración del Estado hacia el Congreso Nacional en materia presupuestaria y financiera, los requirentes, a su vez, aducen que "mediante glosas específicas, insertas en las distintas partidas de la ley de Presupuestos, se exigen (sic) a los diferentes ministerios entregar periódicamente a la Comisión Especial Mixta de Presupuestos (en su mayoría en forma trimestral) información respecto de los beneficiarios de diferentes programas, criterios de elección de éstos, monto de recursos asignados y la modalidad de asignación, individualización de proyectos beneficiados y de personas o entidades ejecutoras, y la distribución a nivel regional y comunal de los recursos ejecutados". De esta forma, indican, lo que se le exige a la Administración es informar en materias ligadas exclusivamente con "el grado y forma de ejecución del gasto estimado en la respectiva ley", lo que excluiría otro tipo de aspectos, como podrían ser las "promesas" o los "compromisos" de carácter político, que son adquiridos por "las autoridades del Ejecutivo", pero que no tienen expresión o carácter normativo y que incluso pueden contemplar asuntos ajenos a la idea matriz y a la naturaleza de la ejecución presupuestaria. Entrando al fondo de la cuestión que se plantea en el requerimiento de autos, los senadores requirentes plantean que las glosas impugnadas presentan los siguientes vicios de inconstitucionalidad de forma: En primer lugar, se afirma que aquéllas excederían la idea matriz del proyecto de ley 
de que se trata, incumpliéndose así lo dispuesto en el artículo 69 de la Carta Fundamental. En esta parte del requerimiento se efectúa una síntesis de los pronunciamientos que esta Magistratura Constitucional ha emitido en torno al concepto de idea matriz del proyecto de ley de presupuestos, partiendo con la referencia a la sentencia de 19 de enero de 1972 y continuando con la más reciente dictada en el Rol 1005, de 24 de diciembre de 2007. Acuden, también, a la cita de doctrina especializada y de normas atinentes contenidas en el Decreto Ley n. 1.263, de 1975 (artículo 9o, entre otros). Tomando esos antecedentes como base, señalan que el Presupuesto del Sector Público constituye "un cálculo anticipado de los ingresos y gastos de la nación" para el período de un año y que ésa, además, sería la idea matriz del proyecto de ley por medio del cual aquél se debe aprobar. Añaden que esa idea matriz o fundamental, a diferencia de la de otra clase de legislación, no es de libre determinación, sino que se encuentra fijada y circunscrita por la Constitución, en su artículo 67. En razón de lo anterior concluyen que las glosas 05 y 06 impugnadas infringen la idea matriz de la Ley de Presupuestos prevista en la Constitución, pues no se encuentran referidas directamente a los ingresos o gastos públicos, sino que consagran un deber de informar relacionado con el cumplimiento de normas que tampoco tienen el carácter de disposiciones legales concretas y que se refieren a ciertos compromisos o metas programáticas asumidas por el Jefe de Estado para ser cumplidas durante su mandato, como son el de extender el descanso maternal hasta 6 meses después del parto y la eliminación del $7 \%$ de la cotización de salud para los pensionados. De esta forma, a juicio de los requirentes, se estaría utilizando indebidamente el proyecto de ley en examen como instrumento de control del cumplimiento de promesas asumidas por las autoridades políticas del país. Se aduce asimismo que siendo el de Presupuestos un proyecto de ley que da origen a una ley anual, conforme a lo dispuesto en la Constitución, las glosas cuestionadas no debieran regular materias relacionadas con políticas públicas que se encuentran recogidas en otros cuerpos legales de carácter permanente, como efectivamente lo hacen. Se pone de relieve, en este aspecto, que cualquier iniciativa legislativa que diga relación con el permiso post natal, al que alude la glosa n. 05 impugnada, debiera verificarse en el ámbito del Código del Trabajo y del Decreto con Fuerza de Ley n. 44, del Ministerio del Trabajo, de 1978, que establece el cálculo de subsidios, topes, requisitos de afiliación y cotización. $Y$, a su vez, cualquier proyecto de ley referido al $7 \%$ de cotización de salud debiera abordarse dentro de la regulación contenida en el Decreto Ley n. 3.500, de 1980, en relación con el Decreto con Fuerza de Ley n. 1, del Ministerio de Salud, de 2005. El segundo vicio de inconstitucionalidad de forma que denuncian los senadores requirentes consiste en que, al haber tenido origen en indicaciones parlamentarias que inciden en la administración financiera del Estado, en la modificación de normas de seguridad social y en la determinación de nuevos deberes y potestades para ciertos órganos públicos, las glosas impugnadas invadirían el ámbito de materias de iniciativa legislativa exclusiva presidencial, previsto en el inciso tercero y en los numerales $2^{\circ}$ y $6^{\circ}$ del inciso cuarto del artículo 65 de la Carta Fundamental. Consta en autos que el requerimiento en examen fue admitido a tramitación por el Tribunal mediante resolución dictada el 9 de diciembre de 2010. Con fecha 7 de diciembre de 2010 ingresó al Tribunal una presentación suscrita por un grupo de 9 diputados en la que se solicitó al Tribunal declarar inadmisible el requerimiento, argumentando su extemporaneidad. Teniendo presente las consideraciones hechas valer en dicho escrito y examinada la acción deducida conforme a las exigencias constitucionales y legales pertinentes, por resolución fechada el 14 de diciembre pasado, el Tribunal declaró admisible el requerimiento formulado en autos y dispuso ponerlo en conocimiento del Presidente 
de la República, del Senado y de la Cámara de Diputados para que, dentro del plazo previsto en el artículo 67, inciso segundo, de la Ley Orgánica Constitucional de esta Magistratura, hicieran llegar sus observaciones y los antecedentes que estimaren necesarios. El Presidente de la República, en escrito de 19 de diciembre de 2010 , suscrito, además, por el señor Ministro Secretario General de la Presidencia, formuló observaciones y acompañó antecedentes solicitando acoger la acción planteada. A su vez, como consta a fojas 899, el Tribunal ordenó tener presente las consideraciones que hizo valer la Cámara de Diputados, representada por su Presidenta, en escrito ingresado el día 20 de diciembre del año en curso, con el objeto de fundar la petición de que el requerimiento en examen sea rechazado en definitiva. OBSERVACIONES DEL PRESIDENTE DE LA REPÚBLICA A FAVOR DEL REQUERIMIENTO MATERIA DE ESTE PROCESO CONSTITUCIONAL: En su presentación el Jefe de Estado, básicamente, apoya la argumentación que han hecho valer los honorables senadores requirentes para justificar las inconstitucionalidades de forma que afectarían a las glosas del proyecto de ley de Presupuestos del Sector Público para el año 2011 que se han impugnado en el libelo y agrega que, a su juicio, también se configurarían vicios de inconstitucionalidad de fondo. En concreto, en cuanto a las Glosas 05 y 06, denominadas ampliación del postnatal y supresión del $7 \%$ de salud de los pensionados, respectivamente, el Jefe del Estado sostiene que el deber de información que ellas establecen configura una extralimitación de atribuciones por parte del Congreso Nacional, en cuanto se entromete en las funciones que son propias del Presidente de la República en su calidad de "más poderoso colegislador" y de Jefe del Gobierno y de la Administración del Estado. En este sentido, se denuncia que las referidas glosas admiten que el Congreso Nacional intervenga en la formulación y en el diseño de políticas públicas, lo que sólo compete al Presidente de la República con la colaboración de sus Ministros de Estado, conforme a lo establecido en los artículos 24 y 33 constitucionales. Con ello se alteraría, asimismo, el régimen presidencial y el sistema de frenos y contrapesos entre las distintas funciones del Estado que se contemplan por la Carta Fundamental. En segundo lugar, el Ejecutivo plantea que estas glosas "se han saltado" la etapa de formulación y discusión que es propia del procedimiento que ha de seguir el Presupuesto de la Nación y que se encuentra a cargo de la Dirección de Presupuestos del Ministerio de Hacienda. En cuanto concierne a la Glosa 09, que ordena, como ya se ha señalado, que la Encuesta Nacional Urbana de Seguridad Ciudadana que el Ministerio del Interior debe practicar para determinar el nivel de victimización de los habitantes de cada comuna, para efectos de la asignación de recursos prevista en el respectivo programa, deba efectuarse por el Instituto Nacional de Estadísticas, el Presidente de la República denuncia que su inconstitucionalidad obedece a que, por una parte, vulnera los principios de eficiencia y eficacia que rigen la actuación de los órganos de la Administración del Estado, conforme a lo establecido en los artículos $3^{\circ}, 5^{\circ}$ y $62, n$. 8a de la Ley Orgánica Constitucional de Bases Generales de la Administración del Estado, en relación con el inciso primero del artículo $8^{\circ}$ de la Ley Fundamental, que consagra el principio de probidad. Lo anterior, ya que el mencionado organismo público no tendría las "competencias específicas" para ejercer esa función, si se atiende a lo normado en el artículo $2^{\circ}$ de su Ley Orgánica, contenida en la Ley $n$. 17.374, y, además, denuncia que la ejecución de dicha tarea distraería recursos públicos, humanos y materiales, siempre escasos. En este punto, se pide considerar que durante la tramitación del proyecto de ley de que se trata, el Ejecutivo, sin éxito, tuvo la intención de incorporar una norma que establecía la externalización del desarrollo de esta encuesta, a entes privados previa competencia verificada dentro de un proceso de licitación, lo que, 
precisamente, perseguía optimizar el uso de los recursos públicos. Por otra parte, se plantea que la Glosa 09 estaría viciada de inconstitucionalidad, toda vez que autorizaría al Estado para la realización de una actividad económica, pero sin los resguardos previstos en el artículo 19, n. 21을 de la Carta Fundamental; en concreto, sin que esta materia se regule por ley aprobada con quórum calificado. OBSERVACIONES DE LA CÁMARA DE DIPUTADOS EN CONTRA DEL REQUERIMIENTO DEDUCIDO EN ESTOS AUTOS: En su presentación, la Cámara de Diputados se refiere, en términos generales, a los caracteres del Presupuesto de la Nación como instrumento de planificación y programación, al carácter estimativo del presupuesto que converge en la flexibilidad en su ejecución y, también, a la Ley de Presupuestos propiamente tal, haciendo hincapié en su naturaleza especialísima, por su contenido y por las reglas que determinan su tramitación. Alude también esa Corporación al concepto de "idea matriz" de un proyecto de ley, el cual, indica, se extrae del Texto Constitucional, de los "requisitos técnicos materiales que debe cumplir el acto legislativo para asegurar su eficacia y conveniencia", como también de la jurisprudencia emanada de esta Magistratura Constitucional (STC de 19 de enero de 1972 y roles ns. 254, 410 y 768). En síntesis, expresa que la idea matriz o fundamental se incorporó al ordenamiento constitucional por la reforma aprobada en el año 1970, como una forma de evitar las llamadas "leyes misceláneas" y, en cuanto a su concepto, éste sería de carácter amplio y comprensivo de la representación intelectual del asunto que se quiere abordar o problema que se desea resolver con el proyecto de ley; por ende, la idea matriz, a juicio de la Cámara de Diputados, debe estar contenida en el Mensaje o Moción, respectivos. A su vez, argumenta que si las adiciones o indicaciones que se formulen durante la tramitación del proyecto de ley deben relacionarse y ajustarse a esta idea matriz en la forma de una "relación causal sincera", ellas también han de considerarse para determinar cuál es la idea matriz propia del proyecto de ley de que se trate. Se agrega que para la determinación de la idea matriz de un proyecto de ley también habrá que acudir a la discusión general del mismo proyecto en que se apruebe la idea de legislar en la respectiva Cámara o al fundamento del veto presidencial si existiere y, en fin, a todo antecedente legislativo en que ella se deduzca. La Cámara de Diputados también se refiere a la obligación de entrega de información que pesa sobre los órganos de la Administración del Estado, que se contiene en las leyes de presupuestos, la cual sería una concreción legal del principio constitucional de publicidad de las actuaciones públicas consagrado en el inciso segundo del artículo $8^{\circ}$ de la Ley Suprema. Refiriéndose al fondo de la cuestión debatida en este proceso, el organismo afirma que las tres glosas del proyecto de ley de Presupuestos que se impugnan por los honorables senadores que suscriben el requerimiento se inscriben dentro del referido principio de publicidad e inciden directamente en dos de las cuatro prioridades que tiene el mismo proyecto, según el Mensaje que inició su tramitación legislativa: la seguridad ciudadana y la salud y, por consiguiente, no serían contrarias a la Carta Fundamental. En particular, respecto de la Glosa 09 sobre seguridad pública, se señala que la realización de la encuesta de que se trata por parte del Instituto Nacional de Estadísticas (INE) no fija una atribución o función a este organismo público ni tampoco interferiría en la disposición del gasto público, por cuanto el deber y la facultad de realizar encuestas ya se encuentran radicados en el mismo ente administrativo por disposición legal precisa contenida en la letra d) del artículo $2^{\circ}$ de la Ley n. 17.374 - orgánica de la entidad - . También se sostiene que esta Glosa debe ser analizada en conjunto con la signada con el $n$. 8, que hace expresa mención a la victimización de los habitantes de la comuna, según datos que refleje la encuesta en cuestión realizada por el mismo Instituto. Sobre las glosas 05 y 06, de la Partida 08 
Ministerio de Hacienda, también cuestionadas en este proceso, la Cámara de Diputados expresa que éstas no hacen más que determinar la entrega de información, por parte de los entes públicos competentes, sobre dos materias que han estado presentes tanto en el programa del actual gobierno como en la exposición sobre el estado de la Nación que el Presidente de la República realizó ante el Congreso Nacional el pasado 21 de mayo. También tratan temas prioritarios del proyecto de ley de Presupuestos, conforme se declaró en su Mensaje. Por ello, no vulnerarían las ideas matrices o fundamentales del proyecto. El deber de información que establecen tales disposiciones que, como se ha señalado, responden a compromisos presidenciales, se inscribiría dentro de las normas sobre acceso a la información pública que buscan una mejor ejecución de los gastos y de la administración financiera del Estado; por lo tanto, la Cámara informante entiende que tales glosas no imponen, ni regulan y tampoco generan una iniciativa de gasto. Tampoco incidirían en materias de seguridad social, sino que lo que han hecho los parlamentarios al formular la respectiva indicación al proyecto de ley es una "adición" conforme a la facultad que se les reconoce en el artículo 69 constitucional. Se estima igualmente constitucional que el Congreso Nacional solicite información a la Administración del Estado, dentro del ejercicio presupuestario, ya que el acceso a la información pública tiene como objetivo el control de los gastos y, en particular, permite a ese organismo ejercer su rol como ente fiscalizador de los actos del gobierno, de acuerdo con lo establecido en el artículo 52 de la Carta Fundamental. Finalmente, el Órgano Legislativo pide a esta Magistratura tener presente que para el año 2011 el Presupuesto de la Nación contempla, en la Partida Tesoro Público, los recursos necesarios para financiar tanto proyectos de ley que se encuentran en actual tramitación legislativa como también los que se requieran para los proyectos que el Ejecutivo contempla tramitar durante el referido año. Y que las glosas impugnadas, justamente, buscan precisar si el Ejecutivo financiará con cargo a dichos recursos tanto el término del $7 \%$ de cotización de salud para los pensionados como el aumento a 6 meses del post natal, o lo hará con otras fuentes de financiamiento. Se aduce que estas mismas glosas fueron incorporadas en otras partidas del mismo proyecto de ley, siendo aprobadas por amplias mayorías, como aparece en la sesión 100ª , páginas 152 y 173, cuya acta se acompaña a la presentación. VISTA DE LA CAUSA: Habiéndose traído los autos en relación y, de conformidad con lo resuelto por el Tribunal a fojas 378, el día veintitrés de diciembre de dos mil diez se procedió a la vista de la causa, oyéndose la relación y, previo anuncio escrito, los alegatos de la abogada Olga Feliú Segovia, por los senadores requirentes. PRÓRROGA DEL PLAZO PARA DICTAR SENTENCIA EN ESTE PROCESO CONSTITUCIONAL: POI resolución fundada expedida el 23 de diciembre de 2010, el Tribunal amplió en diez días el plazo previsto en el inciso quinto del artículo 93 de la Constitución. CONSIDERANDO: I. CONSIDERACIÓN PREVIA: PRIMERO. Que, previamente, es preciso señalar que resulta innecesario entrar a dilucidar la naturaleza jurídica de las glosas de la Ley de Presupuestos, teniendo en cuenta su carácter complejo, dados los guarismos, partidas, ítems y demás clasificaciones presupuestarias que la conforman, por lo cual, para los efectos de resolver el presente conflicto constitucional, esta Magistratura estimará que las glosas forman parte de dicha ley y, por tanto, pueden ser objeto de requerimiento de inconstitucionalidad en los términos previstos en el n. $3^{\circ}$ del inciso primero del artículo 93 de la Constitución. Así se desprende, por lo demás, del fallo Rol 1005, de 2007, de este Tribunal, que señala en su considerando decimosegundo: "Que, como se aprecia, no hay obstáculo para que en la ley anual de presupuestos se incluyan normas sobre materias relativas a su ejecución o a la administración financiera del Estado..."; este mismo Tribunal ha precisado que "la voz 
indicación, referida a un proyecto de ley, comprende, para la técnica legislativa, toda proposición tendiente a corregir o adicionar un proyecto durante la etapa de su discusión y aprobación." (Sentencias roles 259 y 271). Las glosas impugnadas fueron introducidas como indicaciones parlamentarias y fueron tratadas como tales por el Congreso Nacional y por el Poder Ejecutivo; II. RESPECTO DE LA IMPUGNACIÓN PLANTEADA EN CONTRA DE LA GLOSA 09, PARTIDA 05 (MINISTERIO DEL INTERIOR), CAPÍTULO 01, PROGRAMA 05 (SEGURIDAD Y PARTICIPACIÓN CIUDADANA): SEGUNDO. Que, en primer lugar, este Tribunal resolverá el requerimiento respecto de lo planteado sobre la Glosa 09, Partida 05 (Ministerio del Interior), Capítulo 01, Programa 05 (Seguridad y Participación Ciudadana); TERCERO. Que, como ya se indicó en la parte expositiva de esta sentencia, la Glosa 09 impugnada dispone: "La Encuesta Nacional Urbana de Seguridad Ciudadana (ENUSC) que deberá realizarse anualmente por el Instituto Nacional de Estadísticas. La distribución de los fondos de seguridad ciudadana a las comunas, se hará en consideración al nivel de victimización exhibida por dicha comuna en la Encuesta Nacional Urbana de Seguridad Ciudadana realizada por el Instituto Nacional de Estadísticas (INE) en el año inmediatamente anterior"; CUARTO. Que, como consta en las actas de sesiones de la Cámara de Diputados, dicha Glosa 09 fue introducida por indicación n. 8 de los diputados señores Burgos, Harboe, Ortiz y Montes y de las diputadas señoras Sepúlveda y Pacheco, presentada en la Sala de la Cámara de Diputados, en Sesión n. 100. Asimismo, consta que dicha glosa, aprobada en la Cámara de Diputados luego de rechazarse la declaración de inadmisibilidad que había formulado la Presidenta de esa Corporación, dio origen a una indicación sustitutiva del Ejecutivo en el Senado, que fue rechazada. Al debatir la glosa 09 varios senadores hicieron expresa reserva de constitucionalidad; QUINTO. Que del análisis de la glosa impugnada se desprende que ella regula las siguientes materias: en primer lugar, establece quién deberá realizar la Encuesta Nacional Urbana de Seguridad Ciudadana, ordenando que dicha tarea corresponderá al Instituto Nacional de Estadísticas; en segundo lugar, dispone la forma en que deberá efectuase la distribución de los recursos de la Dirección de Seguridad Ciudadana del Ministerio del Interior, según el nivel de victimización de las comunas que arroje la encuesta del año anterior; SEXTO. Que, conforme al artículo 65 de la Constitución, las leyes pueden originarse por mensaje de Presidente de la República o por moción de cualquiera de los miembros de la Cámara de Diputados o del Senado. Las mociones no pueden ser firmadas por más de diez diputados ni por más de cinco senadores. Carecen de iniciativa legislativa todos los demás órganos del Estado. Los órganos facultados para dar inicio a la discusión de un proyecto de ley pueden, por regla general, hacerlo respecto de la generalidad de las materias propias de ley; SÉPTIMO. Que, sin perjuicio de la regla general enunciada en el considerando anterior, la Constitución establece que ciertas materias legislativas únicamente pueden ser de iniciativa del Presidente de la República, las cuales son enumeradas fundamentalmente en el artículo 65. Entre ellas se encuentra la administración financiera o presupuestaria del Estado, incluyendo las modificaciones de la Ley de Presupuestos; OCTAVO. Que las normas sobre iniciativa exclusiva son limitaciones constitucionales al proceso de formación de la ley, en orden a que sobre ciertas materias sólo el Presidente puede hacer propuestas legislativas, sea por la vía del mensaje, sea mediante indicaciones o formulando vetos, por lo que, como reglas de excepción de derecho estricto, deben ser interpretadas restrictivamente; NOVENO. Que la Constitución de 1925 consagraba la iniciativa exclusiva del Presidente de la República especialmente respecto de suplementos a partidas o ítems de la Ley General de Presupuestos. Al analizar los fundamentos de esta limitación a la iniciativa legislativa, la doctrina señala: "A poco 
andar el sistema legislativo diseñado por el constituyente de 1925, se advirtió que los parlamentarios no eran capaces de sustentar o apoyar una conducción económica pública unitaria. En efecto, los intereses de cada congresal movían a promover iniciativas legales con impacto económico siguiendo las necesidades particulares de cada clientela política. Para un Poder Ejecutivo deseoso de invertir recursos fiscales en programas de desarrollo técnicamente planificados, este casuismo económico representaba el creciente alejamiento de la posibilidad de llevar adelante una gestión de gobierno exitosa. De allí que ya a mediados de los años treinta el Presidente comience a reclamar la aprobación de una reforma constitucional que acabe con la iniciativa económica de los parlamentarios." (ALDUNATE L., EDUARDO; BRONFMAN V., ALAN, CORDERO Q., EDUARDO: Informe Final del Estudio "Actualización de Normas y Prácticas Parlamentarias”, encargado por el Ministerio Secretaría General de la Presidencia, Santiago, 2009); DÉCIMO. Que la iniciativa exclusiva del Presidente de la República fue fortalecida en las reformas constitucionales de 1943, durante el mandato del Presidente Juan Antonio Ríos, que agregó a las materias de iniciativa exclusiva: 1) la alteración de la división política o administrativa del país; 2) la creación de nuevos servicios públicos o empleos rentados; y 3) la concesión o aumento de sueldos y gratificaciones al personal de la administración pública, de las empresas fiscales y de las instituciones semifiscales. El Presidente Jorge Alessandri intentó ampliar su radio de acción, lo que sólo se logró por insistencia del Presidente Eduardo Frei Montalva en el año 1970, aprobándose una reforma constitucional en que las nuevas materias reservadas correspondían a: 1) suprimir, reducir o condonar impuestos o contribuciones de cualquier clase, sus intereses o sanciones, postergar o consolidar su pago y establecer exenciones tributarias totales o parciales; 2) fijar o modificar las remuneraciones y demás beneficios pecuniarios del personal de la administración del Estado, tanto centralizada como descentralizada; 3) fijar los sueldos o salarios mínimos de los trabajadores del sector privado, aumentar obligatoriamente sus remuneraciones y demás beneficios económicos o alterar las bases que sirvan para determinarlos; 4) establecer o modificar los regímenes previsionales o de seguridad social; 5) conceder o aumentar, por gracia, pensiones u otros beneficios económicos; y 6) condonar las sumas percibidas indebidamente por concepto de remuneraciones $u$ otros beneficios económicos, pensiones de jubilación, retiro o montepío o pensiones de gracia; DECIMOPRIMERO. Que la Constitución de 1980 mantuvo, con algunos ajustes, las materias de iniciativa exclusiva. A ellas agregó las siguientes: 1) todos los proyectos que tengan relación con la administración financiera o presupuestaria del Estado, incluyendo las modificaciones de la Ley de Presupuestos; 2) contratar empréstitos o celebrar otra clase de operaciones que puedan comprometer el crédito o la responsabilidad financiera del Estado, de las entidades semifiscales, autónomas, de los gobiernos regionales o de las municipalidades, y condonar, reducir o modificar obligaciones, intereses $u$ otras cargas financieras de cualquier naturaleza establecidas a favor del Fisco o de los organismos o entidades referidos; 3) establecer modalidades y procedimientos de la negociación colectiva y determinar los casos en que no se podrá negociar; 4) fijar normas sobre enajenación de bienes del Estado o de las municipalidades y sobre su arrendamiento y concesión; 5) fijar las fuerzas de aire, mar y tierra que han de mantenerse en pie en tiempo de paz o de guerra, y las normas para permitir la entrada de tropas extranjeras en el territorio de la República, como, asimismo, la salida de tropas nacionales fuera de él; DECIMOSEGUNDO. Que, como se aprecia de la evolución constitucional reseñada, ha sido una constante desde el año 1925 que dentro de las normas sobre iniciativa exclusiva del Presidente de la República se incluyan las materias que implican gasto público y las que afectan la 
administración financiera del Estado; DECIMOTERCERO. Que las normas constitucionales sobre iniciativa exclusiva del Presidente de la República en materias legislativas guardan estrecha relación con la forma como nuestra Carta Fundamental ha consagrado el régimen presidencial de Gobierno. Tales normas permiten resguardar, asimismo, las esferas de competencia que la Constitución ha reservado para el Presidente de la República. En este sentido, se ha señalado que "el constituyente desea que todas las leyes que tengan un impacto económico en la vida nacional, sean iniciadas por quien tiene a su cargo 'el gobierno y la administración del Estado', quien es el Jefe de Estado: el Presidente de la República (art. 24)." (FERMANDOIS V., ARTURO Y GARCÍA G., JOSÉ: "Origen del Presidencialismo Chileno: Reforma Constitucional de 1970, Ideas Matrices e Iniciativa Legislativa Exclusiva", en Revista Chilena de Derecho. Vol. 36, n. 2, 2009, p. 297). Este punto adquiere particular relevancia tratándose de la Ley de Presupuestos, que contiene una estimación de los ingresos y gastos del sector público en un año determinado. La historia política y constitucional del país demuestra la importancia que tiene la discusión parlamentaria de esa ley al entrar en juego las atribuciones de ambos poderes colegisladores; DECIMOCUARTO. Que, por otra parte, las normas sobre iniciativa exclusiva previstas en la Constitución son hechas operativas por el artículo 24 de la Ley Orgánica Constitucional del Congreso Nacional, que en sus incisos segundo y tercero señala: "No podrán admitirse indicaciones contrarias a la Constitución Política ni que importen nuevos gastos con cargo a los fondos del Estado o de sus organismos, o de empresas de que sea dueño o en que tenga participación, sin crear o indicar, al mismo tiempo, las fuentes de recursos necesarios para atender a tales gastos. En la tramitación de proyectos de ley los miembros del Congreso Nacional no podrán formular indicación que afecte en ninguna forma materias cuya iniciativa corresponda exclusivamente al Presidente de la República, ni siquiera para el mero efecto de ponerlas en su conocimiento. No obstante, se admitirán las indicaciones que tengan por objeto aceptar, disminuir o rechazar los servicios, empleos, emolumentos, préstamos, beneficios, gastos y demás iniciativas sobre la materia que haya propuesto el Presidente de la República." De ahí que las materias de iniciativa exclusiva no sólo importen la imposibilidad de que los parlamentarios ingresen proyectos de ley sobre tales materias, sino también la imposibilidad de que éstos presenten indicaciones que incidan en ellas; DECIMOQUINTO. Que, concordante con las disposiciones citadas, el artículo 46 de la Constitución prescribe que ambas ramas del Congreso Nacional "concurren a la formación de las leyes en conformidad a esta Constitución", lo que resulta especialmente relevante para los trámites de aprobación de la Ley de Presupuestos, pues ella presenta características especiales. Como ha señalado este Tribunal, "la Ley de Presupuestos disminuye las atribuciones del Congreso y amplía las facultades colegisladoras del Presidente de la República" (C. 21ํ, STC Rol 254), según se puede desprender del artículo 67 de la Constitución; DECIMOSEXTO. Que las materias sobre administración financiera o presupuestaria del Estado son de iniciativa exclusiva del Presidente de la República, conforme lo prescribe el inciso tercero del artículo 65 de la Constitución. Tal como lo recuerda Alejandro Silva Bascuñán, la Constitución actual no estableció explícitamente la necesidad de que se dictara una ley orgánica para fijar las bases del régimen presupuestario. Al hacerlo tuvo en cuenta la existencia del Decreto Ley n. 1.263, de 1975, sobre Administración Financiera del Estado, el cual ha sido modificado en dos oportunidades posteriores a 1990. El Decreto Ley N. 1.263, de 1975, sirve para precisar el concepto de administración financiera o presupuestaria del Estado usado por la Constitución, el cual va más allá de lo monetario y cambiario. En su artículo 5 establece que: "El sistema presupuestario estará constituido por un 
programa financiero de mediano plazo y por presupuestos anuales debidamente coordinados entre sí. Tanto en el programa financiero como en el presupuesto se establecerán las prioridades y se asignarán recursos globales a sectores, sin perjuicio de la planificación interna y de los presupuestos que corresponda cobrar a los servicios integrantes." Luego, su artículo 6o establece que: "Se entiende por administración de fondos, para los efectos de este decreto ley, el proceso consistente en la obtención y manejo de los recursos financieros del Sector Público y de su posterior distribución y control, de acuerdo a las necesidades de las obligaciones públicas, determinadas en el presupuesto. El sistema antes citado operará sobre la base de recaudaciones y de asignaciones globales de recursos, las que se efectuarán a través de la Cuenta Única Fiscal, abierta en el Banco del Estado de Chile, formada por la cuenta principal y las subsidiarias. La cuenta principal se destinará al ingreso de las recaudaciones y al egreso de los giros globales. Estos últimos deberán depositarse en las cuentas subsidiarias pertenecientes a los respectivos servicios"; DECIMOSÉPTIMO. Que corolario de lo razonado en los considerandos precedentes es que la Glosa 09 de la Ley de Presupuestos para 2011, aprobada por el Congreso Nacional, corresponde a una materia de iniciativa exclusiva del Presidente de la República, no obstante lo cual fue incorporada al proyecto de ley respectivo mediante una indicación parlamentaria; DECIMOCTAVO. Que lo anterior es evidente, toda vez que la Glosa 09 impugnada se refiere a la forma en que han de distribuirse los fondos de seguridad ciudadana previstos para la realización de la Encuesta Nacional Urbana de Seguridad Ciudadana. DECIMONOVENO. Que, de esta manera, la referida glosa es una norma destinada a regular la administración de fondos en los términos previstos por el artículo $6^{\circ}$ del Decreto Ley n. 1.263, de 1975, Orgánico de Administración Financiera del Estado; VIGÉSIMO. Que, en consecuencia, la Glosa 09 impugnada por el requerimiento es inconstitucional y así se declarará; VIGÉSIMO PRIMERO. Que, resuelto el conflicto constitucional sometido a este Tribunal de la manera señalada, resulta innecesario emitir pronunciamiento respecto de vicios distintos a aquellos que se han mencionado en los considerandos anteriores y que fueron alegados en autos, como una eventual vulneración a los principios de eficacia y eficiencia de la Administración Pública en relación con el de probidad establecido en el artículo $8^{\circ}$ de la Constitución, así como una hipotética vulneración del artículo 19, n. 21ํㅡㄹ de la misma Carta; III. RESPECTO DE LA IMPUGNACIÓN PLANTEADA EN CONTRA DE LAS GLOSAS 05 Y 06 DE LA PARTIDA 08 (MINISTERIO DE HACIENDA): A. LA IMPUGNACIÓN. VIGÉSIMO SEGUNDO. Que el requerimiento también impugna dos glosas, contenidas en la partida del Ministerio de Hacienda (Partida 08), en el Capítulo 01 (Secretaría y Administración General), Programa 01 (Secretaría y Administración General), signadas con los números 05 y 06. La glosa 05 señala lo siguiente: "05. A más tardar el día 31 de marzo de 2011 la Subsecretaría de Hacienda deberá informar a la Comisión Especial Mixta de Presupuesto sobre las líneas de acción desarrolladas, el cronograma de implementación y aspectos técnicos generales que estén dentro del marco de sus competencias, relacionadas con el compromiso presidencial de extender el descanso de maternidad hasta seis meses después del parto." La glosa 06, por su parte, dispone lo siguiente: "06. A más tardar el día 31 de marzo de 2011 la Subsecretaría de Hacienda deberá informar a la Comisión Especial Mixta de Presupuesto sobre las líneas de acción desarrolladas, el cronograma de implementación y aspectos técnicos generales que estén dentro del marco de sus competencias, relacionadas con el compromiso presidencial de eliminar el 7\% de cotización de salud para los pensionados del país"; VIGÉSIMO TERCERO. Que la impugnación respecto de ambas glosas radica, en primer lugar, en que se excede la idea matriz del presupuesto. La idea 
matriz, se sostiene, es la que sustenta o en la que se apoyan las ideas secundarias o derivadas. Tratándose de la Ley de Presupuestos, la idea matriz está fijada por la Constitución y se refiere a ingresos y gastos. No obstante, puede haber materias relativas a la administración financiera del Estado, en la medida que tengan relación directa con dicha idea. Sin embargo, estas glosas no regulan ni gastos ni ingresos. Se refieren a compromisos que no tienen expresión normativa; son planes; compromisos futuros, hipotéticos o eventuales. Además, dichas glosas obligan a informar sobre compromisos cuya concreción es propia de leyes permanentes, no de una ley anual como la de Presupuesto. En segundo lugar, se dice que dichas glosas invaden la iniciativa exclusiva del Presidente de la República en materia presupuestaria, pues fueron presentadas por diputados durante la tramitación de la Ley de Presupuestos. Dicha invasión se produce, por una parte, porque se consagra un nuevo deber de informar, no reconocido en nuestro sistema. Por la otra, inciden en deberes de seguridad social, pues tienen que ver con el descanso de la maternidad y la supresión de la cotización del 7\% para los pensionados del país; VIGÉSIMO CUARTO. Que el Presidente de la República, a pesar de no haber requerido, en sus observaciones de fecha 19 de diciembre en curso, que rolan a fojas 386 y siguientes, también sostiene la inconstitucionalidad de estas glosas. En primer lugar, porque se excede con ellas la idea matriz del presupuesto, toda vez que los compromisos programáticos del Presidente de la República no son parte de esta ley. La Ley de Presupuestos no es la vía idónea para controlar estos compromisos. Además, abordan materias propias de leyes permanentes. En segundo lugar, el Presidente sostiene que se afecta su iniciativa exclusiva porque se establece una nueva función o atribución para el Ministerio de Hacienda, en el sentido de informar compromisos de carácter político, futuros, hipotéticos o eventuales. El Ejecutivo, durante la tramitación de la respectiva ley, buscó suprimir estas glosas, incorporadas en la Cámara, presentando las respectivas indicaciones en el Senado. Sin embargo, éstas fueron rechazadas. En tercer lugar, a juicio del Ejecutivo, hay otros instrumentos más idóneos para canalizar los deberes de información, que no desvirtúan la Ley de Presupuestos. En este sentido se orientan el Mensaje a la Nación del 21 de mayo de cada año (artículo 24 de la Constitución); las sesiones especiales que la Cámara de Diputados o el Senado convoquen para informarse sobre asuntos de los respectivos Ministerios (artículo 37 constitucional); las facultades fiscalizadoras de la Cámara de Diputados (artículo 52 de la Ley Fundamental); la solicitud de información a los órganos de la administración (Ley n. 18.918, artículos $9^{\circ}$ y siguientes). En cuarto lugar, el Presidente sostiene que se quebranta el régimen presidencial con estas glosas, de un lado, porque el Congreso Nacional pasa a intervenir en la formulación, estudio o elaboración de políticas públicas, rol que de acuerdo al mandato del artículo 24 de la Constitución le corresponde únicamente al Presidente de la República. Del otro, porque se obliga a informar sobre compromisos presidenciales incluidos en su agenda programática, que aún no se manifiestan en medidas concretas. Finalmente, el Ejecutivo afirma que mediante las glosas se afecta el proceso de elaboración presupuestaria, pues ellas se saltaron la etapa de formulación y discusión; B. EXAMEN DE LAS GLOSAS IMPUGNADAS; VIGÉSIMO QUINTO. Que, para hacernos cargo de dichas objeciones, partiremos por analizar las glosas cuestionadas. En primer lugar, éstas establecen una obligación. Ella está definida por los siguientes elementos. Por de pronto, establece un sujeto pasivo, pues quien debe informar es la Subsecretaría de Hacienda. Enseguida, se establece un sujeto activo, ya que la información debe ser remitida a la Comisión Especial Mixta de Presupuestos, no a la Cámara ni al Senado ni a las Comisiones de Hacienda de dichas corporaciones. A continuación, se establece un plazo: la obligación 
de informar debe hacerse a más tardar el 31 de marzo de 2011. Nada impide que se haga antes. Se trata de un acto único, en el sentido de que, entregada la información, se entiende cumplida la obligación. En segundo lugar, estas glosas establecen un deber de informar. Este deber está acotado a través de distintas variables. Desde luego, es un mero deber de informar. La glosa no establece que la Subsecretaría de Hacienda deba comprometerse a algo más que comunicar. Por lo mismo, cabe perfectamente que sostenga que no tiene contemplado avanzar en esta materia durante el año 2011. Los proyectos de ley que su ejecución pueda conllevar, son de iniciativa exclusiva del Ejecutivo. Asimismo, la información que debe proporcionar la Subsecretaría es sólo respecto de lo que esté "dentro del marco de sus competencias". Es decir, lo que tenga que ver con compromisos financieros. Recordemos que la Dirección de Presupuestos, como organismo técnico encargado de proponer la asignación de recursos financieros del Estado (artículo 15 del Decreto Ley n. 1.263, de 1975), se inserta orgánicamente como un servicio dependiente de esta Subsecretaría (D.S. n. 4727/1957, Hacienda, artículo 6o). También la glosa obliga a informar respecto de lo realizado ("líneas de acción desarrolladas"), de un itinerario posible para materializar el compromiso ("cronograma de implementación"), y la manera en que se tiene pensado llevar a cabo el compromiso ("aspectos técnicos generales"). Sin embargo, dicha información no es vinculante ni para el Ejecutivo ni para el Congreso. Ello implica, por una parte, que el Ejecutivo puede cambiar dicho cronograma y la modalidad de materializarlo. Por la otra, la glosa no establece un deber de materializar los compromisos, ni de llevarlos a cabo. Finalmente, este deber se acota por el área de cada glosa. En una (la 05), el deber de informar se relaciona "con el cumplimiento del compromiso presidencial de extender el descanso de maternidad hasta los seis meses después del parto". En la otra (la 06), se refiere al "cumplimiento del compromiso presidencial de eliminar el $7 \%$ de cotización para salud de los pensionados del país". En tercer lugar, las glosas no establecen una manera específica de materializar este deber de información. Por ejemplo, no se exige la concurrencia personal del Subsecretario. Por lo mismo, puede cumplirse por un mero oficio. En cuarto lugar, las glosas reconocen expresamente que tanto la extensión del descanso de maternidad como la eliminación del 7\% no son obligaciones, sino que un "compromiso presidencial". Es decir, palabra dada durante la campaña presidencial; C. CONSIDERACIONES SOBRE EL PRESUPUESTO; VIGÉSIMO SEXTO. Que, antes de entrar a analizar las objeciones formuladas en el requerimiento, es necesario realizar algunas precisiones sobre el presupuesto. En primer lugar, el presupuesto es una ley; una ley especial; pero es mucho más que una ley. Es uno de los principales instrumentos de política económica que tiene un gobierno. Por de pronto, porque en él se delinean los ingresos y gastos de los órganos del Estado para un año calendario. Ello revela un programa de acción y orienta conductas económicas. Enseguida, porque es una enorme cantidad de recursos, que en la actualidad supera los 50 mil millones de dólares; ello equivale a prácticamente un cuarto del PGB del país. Además, el gasto público implica materializar obras (hospitales, caminos, cárceles, viviendas sociales); realizar prestaciones en salud, educación; pagar subsidios, subvenciones, remuneraciones, devolución de impuestos, etc. Esta Magistratura ha señalado que es una herramienta con que cuenta el Estado para satisfacer gran parte de las necesidades públicas (STC 254/97). Asimismo, es un complejo mecanismo que armoniza la recaudación y el gasto, es decir, el retiro de dinero de la economía (los ingresos que lo componen) y la reinserción del mismo vía gasto público. En segundo lugar, esta Magistratura ya ha tenido oportunidad de pronunciarse sobre la Ley de Presupuestos, destacando que ésta requiere una interpretación flexible, racional y lógica, a fin de que su 
operatividad no se vea congelada. Por ello validó que la legalidad presupuestaria fuera atenuada y flexible, entregando al Ejecutivo todas las potestades indispensables para que pudiera llevarla a cabo (STC Rol 254/1997). En tercer lugar, como consecuencia de que al Presidente se le encarga el gobierno y la administración del Estado (artículo 24, Constitución), el Ejecutivo goza de enormes poderes respecto de la Ley de Presupuestos. Por de pronto, a él le corresponde prepararlo y ejecutarlo. El Congreso sólo interviene en su aprobación. Enseguida, dicha fase de aprobación es restringida, por una parte, porque hay asuntos que ni siquiera van a discusión al Congreso, como la estimación del rendimiento de los recursos. Por la otra, porque el Congreso no puede más que aceptar, disminuir o rechazar lo que el Presidente le proponga. $Y$ no puede reducir los gastos establecidos en leyes permanentes. Asimismo, si el Congreso aprueba un gasto desfinanciado, al promulgar la ley el Presidente puede reducir proporcionalmente los gastos que no cuenten con el debido financiamiento. Finalmente, el Congreso tiene un plazo limitado para su análisis: sesenta días desde su presentación. No obstante lo anterior, estas potestades del Ejecutivo no pueden interpretarse sin considerar el rol del Congreso Nacional. Desde luego, porque al Congreso Nacional le corresponde aprobar el presupuesto. Ésta no es una función menor ni carente de significado. Ambas Cámaras, con las mayorías respectivas, deben pronunciarse favorablemente para que haya un presupuesto aprobado formalmente y no por silencio. Enseguida, el Congreso dispone de la potestad de disminuir o rechazar los gastos. Al ejercerla, obliga al Ejecutivo a iniciar conversaciones para reponer lo rebajado $y$ atender los requerimientos parlamentarios que fundan dicha rebaja; VIGÉSIMO SÉPTIMO. Que, en cuarto lugar, para nadie es un misterio que la aprobación de la Ley de Presupuestos es un ejercicio de negociación política que tiene dos etapas. Una se lleva a cabo antes de su envío. Todos los organismos del sector público tienen que presentar sus propuestas de ingresos y gastos a la Dirección de Presupuestos, de acuerdo al calendario que ésta determine (artículo 13 del D.L. n. 1.263). Esta repartición, en conjunto con el Ministro de Hacienda, el Ministro sectorial respectivo y el Presidente de la República, definen los gastos que en definitiva serán propuestos para cada órgano al Congreso Nacional, de acuerdo a los recursos disponibles y a los objetivos, metas y prioridades de cada gobierno. La segunda etapa se lleva a cabo entre el Ejecutivo y el Congreso Nacional. El presupuesto es aprobado luego de conversaciones y diálogos formales e informales, en que se llega a acuerdos, transacciones y compromisos, que se reflejan en indicaciones y protocolos complementarios a la ley. Dicha negociación no tiene nada de malo o espúreo; es la consecuencia de que la facultad de aprobación radica en un órgano plural y representativo de la sociedad. Además, dicha negociación se realiza de un modo transparente, en que sus avances y retrocesos, si bien pueden escapar al ciudadano común, no escapan a la atenta mirada de un observador avezado. A fin de que esta negociación no se dilate, existe el plazo de sesenta días para que el Congreso despache el presupuesto. Como consecuencia de lo anterior, las potestades con que la Constitución dota al Ejecutivo no pueden interpretarse estáticamente y descontextualizadas de la realidad en que operan. Es más, considerarlas de manera binaria, es decir, que el rol del Congreso se limite a aceptar o rechazar, puede llevar a rigidizar el proceso de negociación de esta importantísima ley; VIGÉSIMO OCTAVO. Que, en quinto lugar, producto de este ejercicio de negociación y a pesar de las enormes potestades del Ejecutivo, el Congreso Nacional ha logrado avanzar en materia de información del gasto público. En efecto, progresivamente nuestro ordenamiento jurídico ha establecido mayores deberes de información a favor del Congreso Nacional en materia presupuestaria. Ello se refleja de varias maneras. Primeramente, en la propia Ley de 
Presupuestos. Si se analizan las leyes de presupuestos desde el año 1990 en adelante, se observa que el actual artículo 15, que obliga a entregar una serie de informes al Congreso, recién aparece en el presupuesto del año 1995. Los presupuestos de los años 91 (Ley n. 19.012), 92 (Ley n. 19.103), 93 (Ley n. 19.182) y 94 (Ley n. 19.259) no contemplaban una normativa de esta naturaleza. Dichos deberes de información, sin embargo, fueron tímidos al principio. El artículo respectivo, cuya numeración varía de ley en ley, no tenía en un principio más que cuatro incisos. Entre el presupuesto del año 1995 (Ley n. 19.356) y el presupuesto del año 2002 (Ley n. 19.774), estos cuatro incisos permanecen estables. Es a partir del presupuesto del 2003 (artículo 18, Ley $n$. 19.842) que los incisos comienzan a aparecer más intensamente: cinco en el presupuesto del 2003; ocho en el del 2004 (artículo 14, Ley n. 19.915), 2005 (artículo 14, Ley n. 19.986) y 2006 (artículo 16, Ley n. 20.083); once en el presupuesto del 2007 (artículo 15, Ley n. 20.141); doce en el presupuesto del 2008 (artículo 15, Ley n. 20.232); trece en el 2009 (artículo 15, Ley n. 20.314); quince en el de 2010 (artículo 15, Ley n. 20.481). Cada inciso o numeral equivale a una obligación específica de informar al Congreso Nacional. Enseguida, estos mayores deberes de información se reflejan en el carácter permanente de la Comisión Especial Mixta de Presupuesto, que le dio la Ley n. 19.875, el año 2003. Con anterioridad a esta normativa, dicha Comisión agotaba su trabajo informando a la Cámara y al Senado, para efectos de su aprobación, el contenido del proyecto de ley anual de presupuestos. A contar de la Ley n. 19.875, esta Comisión se hizo permanente, en el sentido de que sigue funcionando después de despachado el presupuesto. Además, se le dio un propósito: "realizar un seguimiento de la ejecución de la Ley de Presupuestos durante el respectivo ejercicio presupuestario." Para tal efecto, puede "solicitar, recibir, sistematizar y examinar la información relativa a la ejecución presupuestaria proporcionada por el Ejecutivo". Asimismo, estos mayores deberes de información se expresan en que por modificaciones introducidas a la Ley de Administración Financiera del Estado, el año 2003, por la Ley n. 19.896, el Ministerio de Hacienda está obligado a enviar al Congreso Nacional los resultados de los informes que se emitan por aplicación de las evaluaciones que empresas auditoras realicen de los programas sociales, de fomento productivo y de desarrollo institucional que año a año se definan en la Ley de Presupuestos (artículo 52, D.L. n. 1.263). A continuación, estos mayores deberes de información del Ejecutivo al Congreso Nacional se trasuntan en las glosas de la Ley de Presupuestos. Éstas también establecen deberes de información asociados a ciertos gastos. De hecho, en la Ley de Presupuestos del año 2011 se contemplan varias glosas equivalentes a las impugnadas. Así, en el Ministerio de Educación, se contempla la de informar sobre la forma de resolver el problema de la deuda histórica con el Magisterio (Partida 09, Capítulo 01, Programa 01, Glosa 16); en el de Salud, se obliga a informar las metas de reducción de las listas de espera (Partida 16, Capítulo 09, Programa 01, Glosa 16). Dichas glosas no fueron objetadas en el presente requerimiento. $Y$ en cada Partida de la Ley de Presupuestos se observan glosas destinadas a que órganos de la administración informen al Congreso sobre el gasto autorizado; VIGÉSIMO NOVENO. Que estos deberes de información que el legislador diseña a propósito de la ejecución presupuestaria, son distintos y separados del resto de las obligaciones de información que regula nuestro sistema, como la que se enmarca dentro de las facultades fiscalizadoras de la Cámara (artículo 52, n. 1, letra a), inciso segundo, así como letras b) y c)); de las sesiones especiales que la Cámara de Diputados o el Senado convoquen para "informarse sobre asuntos que, perteneciendo al ámbito de atribuciones de las correspondientes secretarías de Estado, acuerden tratar" (artículo 37) o de los informes y antecedentes específicos que los parlamentarios o las comisiones pueden 
solicitar a los órganos de la administración del Estado, en virtud de los artículos $9^{\circ}$ y siguientes de la Ley Orgánica Constitucional del Congreso Nacional (Ley n. 18.918). En ello, el legislador sigue la lógica de la Constitución, de diseñar instrumentos específicos para la Ley de Presupuestos. Sin embargo, estos instrumentos tienen elementos comunes. Por una parte, los que se encuentran en la Constitución (artículos 37 y 52) fueron incorporados por la reforma constitucional del 2005. Por la otra, todos tienen que ver con información que el Ejecutivo debe entregar al Congreso. En efecto, las sesiones especiales son para que las Cámaras puedan "informarse" sobre lo que están realizando los distintos ministerios (artículo 37). En materia de fiscalizaciones, cualquier diputado, con el voto favorable de un tercio de los miembros presentes de la Cámara, "podrá solicitar determinados antecedentes al Gobierno" (artículo 52 n. 1, letra a)). La interpelación es para "formularle preguntas" a un Ministro de Estado en relación con materias vinculadas al ejercicio de su cargo, estando obligado éste a asistir y "responder las preguntas y consultas que motiven su citación" (artículo 52, $n$. 1, letra b)). $Y$ las comisiones investigadoras son para "reunir informaciones relativas a determinados actos del gobierno". Y los funcionarios que sean citados a ellas deben "suministrar los antecedentes y las informaciones que se les soliciten" (artículo 52, $n$. 1, letra c)). Incluso en un ámbito tan exclusivo para el Presidente de la República como es conducir las relaciones internacionales, la reforma del 2005 obliga a éste a que cuando someta a aprobación del Congreso los tratados, informe a éste "sobre el contenido y alcance del tratado, así como de las reservas que pretenda confirmar o formularle" (artículo $54 \mathrm{n}$. 1). La información, por tanto, ha sido considerada por el constituyente como un elemento indispensable para que el Congreso pueda cumplir su tarea; TRIGÉSIMO. Que no es extraño, entonces, que estos deberes de información permitan afirmar que se ha configurado un nuevo principio que regula al presupuesto. Además de los clásicos de legalidad (no se puede gastar sin autorización previa), equilibrio presupuestario (los gastos deben corresponder a los ingresos, sin que pueda haber gastos desfinanciados), preponderancia del Ejecutivo (iniciativa exclusiva, reducidas potestades del Congreso, exclusividad en la ejecución), anualidad (presupuesto dura un año), unidad (un solo presupuesto para todo el sector público), universalidad (todos los ingresos y todos los gastos que efectúa el Estado se reflejan en el presupuesto; por excepción cabe el tributo de afectación) y especialidad (fecha de presentación y de despacho definidas, tramitación distinta al resto de las leyes, publicación en el Diario Oficial de sólo un resumen de ella, modificación vía potestad reglamentaria), existe ahora el de transparencia. Éste obliga al Ejecutivo a entregar cierta información de la ejecución presupuestaria al Congreso Nacional; TRIGÉSIMO PRIMERO. Que dicho principio ha sido instaurado paulatinamente, en las sucesivas leyes de presupuesto o en modificaciones legales específicas, como la incorporación permanente de la Comisión Especial Mixta de Presupuestos, hecha por la Ley n. 19.875; o la remisión al Congreso Nacional de los informes de evaluación de programas sociales, de fomento productivo y desarrollo institucional que se determinen año a año, contemplada por la Ley n. 19.896. Este principio revela una tendencia que se enmarca dentro del giro que significó la reforma constitucional del 2005 para los órganos del Estado, con la instauración del artículo $8^{\circ}$. Esto obliga a la publicidad de sus actuaciones. Complementando dicha regulación, la ley (Ley n. 20.285) configuró un derecho de acceso a la información pública, que puede invocar cualquier persona. Si bien este derecho es configurado por el legislador respecto a la relación que deben tener con las personas los órganos del Estado, ello no obsta a que la publicidad y la transparencia también sean predicables respecto de las relaciones entre órganos del 
Estado; TRIGÉSIMO SEGUNDO. Que, además, dicha instauración revela un proceso de negociación entre el Congreso y el Ejecutivo, extremadamente delicado, que esta Magistratura, por el principio de corrección funcional, no puede romper, pues revela un equilibrio en el sistema de frenos y contrapesos diseñado conjuntamente por ambos órganos. Las normas que han ido estructurando este principio fueron el resultado de iniciativas del Ejecutivo concordadas con el Congreso o de iniciativas parlamentarias que contaron con el asentimiento del Ejecutivo; TRIGÉSIMO TERCERO. Que la consolidación de este principio sólo es comparable con las sucesivas restricciones que distintas leyes de presupuesto fueron incorporando a la posibilidad del Ejecutivo de modificar la Ley de Presupuestos por decreto. Regulada esta posibilidad en los artículos 26 y 26 bis del D.L. n. 1.263, en los artículos 4o de los presupuestos, a partir del año 1994, con la Ley $n$. 19.259, las leyes de presupuestos fueron restringiendo esa facultad general, agregando nuevas prohibiciones; $\boldsymbol{D}$. LAS GLOSAS IMPUGNADAS NO EXCEDEN LA IDEA MATRIZ DEL PRESUPUESTO. TRIGÉSIMO CUARTO. Que, luego de efectuadas las precisiones anteriores, estamos en condiciones de analizar la primera objeción que se formula en el requerimiento a estas glosas, es decir, que excederían la idea matriz del presupuesto. Estas, se sostiene, no cabrían en la idea que sustenta esta ley especial; TRIGÉSIMO QUINTO. Que esta Magistratura no comparte dicha argumentación. En primer lugar, porque ambos compromisos implican, de materializarse, proyectos de ley. Su elaboración supone estudios, informes, destinación de personal a su elaboración. Es decir, implican gastos. Gastos e ingresos son parte de la idea matriz del presupuesto tal y como se desprende del artículo 67 de la Constitución y de lo afirmado por este Tribunal en sentencia Rol 1005. Si, por el contrario, el Ejecutivo informa que no tiene contemplado durante el año 2011 avanzar en estos compromisos, se entiende que no usará recursos presupuestarios destinados a tal efecto; TRIGÉSIMO SEXTO. Que, en segundo lugar, la propia Ley de Presupuestos contiene un artículo (el 15) que obliga a la Dirección de Presupuestos a proporcionar una serie de informes y documentos a las Comisiones de Hacienda del Senado y de la Cámara de Diputados y a la Comisión Especial Mixta de Presupuestos. La obligación de entregar información está incorporada, entonces, en la idea matriz del presupuesto. De hecho, este artículo era parte del Mensaje con que el Ejecutivo remitió al Congreso Nacional el proyecto de ley de presupuestos. Incluso, en el mismo Mensaje, se indicaba que el proyecto "refleja una nueva forma de gobernar, caracterizada por la responsabilidad y transparencia en el uso de los recursos de todos los chilenos". Mal puede afirmarse, entonces, que estas glosas excedan la idea matriz del Presupuesto; E. LAS GLOSAS IMPUGNADAS NO AFECTAN LA INICIATIVA EXCLUSIVA DEL PRESIDENTE DE LA REPÚBLICA; TRIGÉSIMO SÉPTIMO. Que la segunda objeción que se formula a las glosas es que éstas invadirían la iniciativa exclusiva en materias de ley del Presidente de la República, al establecer un deber de información a la Subsecretaría de Hacienda, es decir, se estaría estableciendo una potestad pública; TRIGÉSIMO OCTAVO. Que tampoco comparte esta Magistratura dicha argumentación. En primer lugar, porque el deber de información que establecen las glosas no es radicalmente distinto del establecido a favor de la Comisión Especial Mixta de Presupuestos, la que, como ya se indicó, puede "solicitar, recibir, sistematizar y examinar la información relativa a la ejecución presupuestaria". En este sentido, no es una atribución innovativa, que modifique radicalmente el ordenamiento jurídico vigente; TRIGÉSIMO NOVENO. Que, en segundo lugar, es importante señalar que la Ley n. 19.875, que incorporó la Comisión Especial Mixta de Presupuestos, de modo permanente en el funcionamiento del Congreso Nacional, fue producto de una moción parlamentaria de los entonces senadores $E$. 
Boeninger, A. Foxley, C. Ominami y del actual senador J. García y de la senadora E. Matthei (Boletín n. 3051-07). Cuando esta Magistratura ejerció el control de constitucionalidad de dicha iniciativa, mediante la sentencia Rol 372/2003, no formuló reproche alguno sobre el hecho de que se haya generado mediante iniciativa parlamentaria, declarando expresamente que sus disposiciones no eran contrarias a la Carta Fundamental. Ello se ve ratificado en el examen de constitucionalidad realizado por esta Magistratura con ocasión de la modificación a la Ley Orgánica del Congreso Nacional (STC Rol 1602/2010), en que las solicitudes de información que pueden formular las comisiones o los parlamentarios a los órganos de la administración, de acuerdo a los artículos $9^{\circ}$ y siguientes, fueron producto de indicaciones del Ejecutivo adicionadas o modificadas por los parlamentarios, o de indicaciones parlamentarias. Tampoco en esta oportunidad se formuló reproche. En este sentido, este Tribunal tiene un criterio en orden a que la solicitud de información del Congreso Nacional al Ejecutivo no es un asunto materia de ley de iniciativa exclusiva del Presidente de la República; CUADRAGÉSIMO. Que, en tercer lugar, estos deberes de información equilibran adecuadamente las enormes potestades del Ejecutivo en materia de gastos, sin ponerlas en entredicho, con las limitadas potestades del Congreso. En efecto, por de pronto, estos deberes de información no implican una intervención en la administración de las finanzas públicas que le corresponde al Presidente de la República (artículos 24 y 32, n. 20). Por una parte, porque no obligan a nada distinto que no sea transferir dichos antecedentes. Ni siquiera dicha información vincula al Congreso o al Ejecutivo. Ella sólo busca que el Congreso pueda conocer la forma en que el Ejecutivo está ejecutando el gasto y asegurarse de que esa ejecución sea concordante con lo que aprobó en su momento. Distinto es que esa información pueda servir para que el Congreso haga uso de otras potestades, en el caso de que considere que dicha ejecución no supera sus expectativas. Por la otra, porque no afecta el proceso de ejecución del gasto. Dicha entrega no afecta la recaudación, la inversión, el ritmo del gasto, el manejo de los recursos financieros del sector público ni su distribución y control (artículo 6으. D.L. n. 1.263). Tampoco implica inmiscuirse en la elaboración del presupuesto. Eso sigue siendo resorte del Ejecutivo. Ni significa, finalmente, un aumento o un nuevo gasto; CUADRAGÉSIMO PRIMERO. Que, enseguida, la propia legislación actual establece que solicitar, recibir, sistematizar y examinar información relativa a la ejecución presupuestaria no puede implicar "ejercicio de funciones ejecutivas, o afectar las atribuciones propias del Poder Ejecutivo, o realizar actos de fiscalización" (artículo 19, inciso final, Ley Orgánica del Congreso Nacional); CUADRAGÉSIMO SEGUNDO. Que, asimismo, tampoco produce esa interferencia el hecho de que un ciudadano cualquiera solicite a la Administración, en ejercicio de su derecho de acceso a la información, copia de ciertos actos o resoluciones que ésta haya emitido. Mal puede, entonces, considerarse que la obligación de entregar cierta información por el Ejecutivo al Congreso produzca dicha distorsión. El Congreso Nacional representa al pueblo (artículo 5o, inciso primero, de la Constitución) en la democracia representativa diseñada por ésta (artículos $4 \stackrel{\circ}{\circ}, 47$ y 49). No puede, por tanto, tener un status desfavorable en relación al simple ciudadano, al momento de acceder a la información del Estado; CUADRAGÉSIMO TERCERO. Que, además, no hay que olvidar que aquí estamos analizando una glosa que establece una potestad en favor del Congreso Nacional y no de un órgano de la administración del Estado. En este último caso, esto es, si la atribución fuese asignada a un órgano administrativo, conforme a lo establecido en el artículo 65, inciso cuarto, n. $2^{\circ}$, de la Constitución, regiría la iniciativa exclusiva del Presidente de la República; CUADRAGÉSIMO CUARTO. Que, de este modo, la entrega de información relativa al gasto público es un mecanismo adecuado y 
proporcional a favor del Congreso, frente a las enormes potestades que el Ejecutivo tiene en materia presupuestaria, que articula una sana relación entre dichos órganos. Dicha entrega no implica ni interferir, ni entrabar, ni entrometerse en la administración financiera del Estado. Es decir, no desnaturaliza la relación entre ambos órganos del Estado. Respeta, por tanto, el principio de interpretación de corrección funcional; $\boldsymbol{F}$. LAS GLOSAS IMPUGNADAS NO QUEBRANTAN EL RÉGIMEN PRESIDENCIAL; CUADRAGÉSIMO QUINTO. Que un tercer reproche que se formula a las glosas se refiere a que quebrantarían el régimen presidencial porque juridifican compromisos presidenciales e intervienen en la formulación, estudio o elaboración de políticas públicas. Tampoco comparte esta Magistratura dicha afirmación. En primer lugar, porque el régimen presidencial es configurado a nivel constitucional, no a nivel presupuestario. Los elementos centrales del régimen presidencial permanecen incólumes, pues el Presidente es electo por la ciudadanía, no por el Congreso, y dura un período fijo (artículos 26 y 30); los Ministros son de la exclusiva confianza del Presidente (artículos 32, n. 7, 52, 57, n. 1, y 59); el Presidente de la República no puede disolver la Cámara ni el Senado (artículos 47 y 49); CUADRAGÉSIMO SEXTO. Que, en segundo lugar y como ya se indicó, las glosas impugnadas sólo obligan a informar sobre ciertos compromisos programáticos. No obligan a materializarlos o a llevarlos a cabo dentro del año presupuestario. La forma en que ello se materialice en determinada política pública y el itinerario de su implementación es algo que sigue siendo de resorte exclusivo del Ejecutivo. En su momento, el Ejecutivo enviará, si así lo estima pertinente, los respectivos proyectos de ley y el Congreso se pronunciará sobre ellos. El hecho de que se obligue al Ejecutivo a informar sobre estos compromisos programáticos en la Ley de Presupuestos obedece, como ya se indicó, a que éstos pueden implicar gastos, tanto en su etapa de formulación (estudios, informes) como en su etapa de ejecución. Dichos compromisos no son algo que interese únicamente al Ejecutivo, ni son algo respecto a lo cual el Congreso no tenga nada que decir; CUADRAGÉSIMO SÉPTIMO. Que, en tercer lugar, existen peticiones de información especiales en materia presupuestaria (artículo 19, Ley n. 18.918; artículo 15, Ley $n$. 20.481) y de fiscalización (artículo 52 de la Constitución) y de informes y antecedentes que se pueden pedir a los órganos de la administración (artículos 9 o y siguientes de la Ley $n$. 18.918), que no desvirtúan el régimen presidencial y que han sido validados por esta Magistratura (STC roles 372/2003; 1602/2010). Más todavía, si las glosas objetadas establecen menos obligaciones que las consagradas en dichas normas. Además, estas otras normas ni siquiera se detienen frente al secreto o reserva de la información solicitada (artículo 9을 incisos segundo y tercero, de la Ley n. 18.918); CUADRAGÉSIMO OCTAVO. Que, en cuarto lugar, cabe tener presente que el Congreso Nacional despachó una ley, impulsada por el Ejecutivo, sobre Asociaciones y Participación Ciudadana en la Gestión Pública (boletín 3562-06), la que se encuentra para control preventivo de esta Magistratura. Esta iniciativa obliga a los órganos de la administración del Estado a "poner en conocimiento público información relevante acerca de sus políticas, planes, programas, acciones y presupuestos, asegurando que ésta sea oportuna, completa y ampliamente accesible. Dicha información se publicará en medios electrónicos u otros", como consecuencia de reconocer a las personas "el derecho de participar en sus políticas, planes, programas y acciones". Dicho proyecto no fue vetado por el Ejecutivo. Sin que implique adelantar juicios sobre el fondo de dicho proyecto, cabe señalar que si el ciudadano común puede, a juicio del Congreso, tener acceso a esta información, no se ven razones para que el Congreso Nacional se vea marginado de ella. Un poder del Estado no puede quedar en peor pie para que pueda cumplir adecuadamente su función de fiscalizar y legislar; CUADRAGESIMO NOVENO. 
Que, finalmente, si estuviera en juego el régimen presidencial, no se entiende que el Ejecutivo no haya vetado la normativa que no compartía. Tampoco, que no haya requerido él directamente, ni que haya aceptado o tolerado glosas de igual sentido y alcance que las objetadas; G. LAS GLOSAS IMPUGNADAS NO VIOLENTAN LA FORMULACIÓN PRESUPUESTARIA; QUINCUAGÉSIMO. Que, por último, el Presidente de la República, en sus observaciones, añade a las objeciones analizadas que las glosas impugnadas violentan la formulación presupuestaria, toda vez que no se sujetaron a las etapas que regulan dicha elaboración; QUINCUAGÉSIMO PRIMERO. Que, a pesar de que esta Magistratura no está obligada a hacerse cargo de ella, pues implica una ampliación del requerimiento, sólo por deferencia hacia quien la formula, emitirá un pronunciamiento. Pero la rechazará; QUINCUAGÉSIMO SEGUNDO. Que, para ello, es necesario señalar que el ciclo presupuestario son las fases por las cuales atraviesa el presupuesto. Este tiene, en nuestro sistema jurídico, tres etapas: la de preparación, la de aprobación y la de ejecución; QUINCUAGÉSIMO TERCERO. Que la etapa de preparación o confección es el conjunto de actos que ocurren dentro del Ejecutivo, destinados a elaborar el proyecto de ley de presupuestos. En este proceso juega un rol clave la Dirección de Presupuestos, organismo dependiente del Ministerio de Hacienda. Esta tiene por misión "proponer la asignación de los recursos financieros del Estado" (artículo 15, D.L. n. 1.263). Esta etapa concluye con el envío al Congreso, "con tres meses de anterioridad a la fecha en que debe empezar a regir" (artículo 67 constitucional), del proyecto de ley de Presupuestos. La etapa de aprobación o de discusión es aquella que ocurre en el Congreso Nacional. El presupuesto es una ley; sólo que una ley especial. Esta etapa comienza con el ingreso a la Cámara de Diputados del proyecto y termina cuando el Congreso lo despacha, con aprobación formal o con silencio positivo por no haberlo despachado "dentro de los sesenta días contados desde su presentación" (artículo 67 aludido). La etapa de ejecución es aquella que comienza con la publicación en el Diario Oficial de "un resumen de la Ley de Presupuestos" (artículo 20, D.L. n. 1.263). Ésta consiste en la percepción o recaudación de los ingresos y en la materialización del gasto previsto en ella; QUINCUAGÉSIMO CUARTO. Que la Constitución regula dos de estas etapas. Por una parte, lo hace respecto de la aprobación, en los artículos 65 y 67. Por la otra, lo hace respecto de la ejecución. Así señala que le corresponde al Presidente de la República decretar la inversión de las rentas públicas con arreglo a la ley (artículo 32, n. 20); que la Contraloría "en ningún caso dará curso a los decretos de gastos que excedan el límite señalado en la Constitución" (artículo 99); que "las Tesorerías del Estado no podrán efectuar ningún pago sino en virtud de un decreto o resolución expedido por autoridad competente, en que se exprese la ley o la parte del presupuesto que autorice aquel gasto" (artículo 100). Dicha regulación es complementada por normas legales. Por ejemplo, en materia de aprobación, la Ley Orgánica del Congreso Nacional se refiere a ello (artículo 19, Ley $n$. 18.918). Y, en lo que se refiere a la ejecución, el D.L. n. 1.263 establece que "el ejercicio presupuestario coincidirá con el año calendario. Las cuentas del ejercicio presupuestario quedarán cerradas al 31 de diciembre de cada año" (artículo 12). La misma normativa agrega que la Dirección de Presupuestos debe proponer al Ministerio de Hacienda "un programa de ejecución del presupuesto en el mes de diciembre del año anterior a su vigencia. Asimismo, confeccionará programas de gastos, denominados Programas de Caja, donde fijará el nivel y prioridad de los mismos" (artículo 22). De acuerdo a dicho programa de ejecución, "se pondrán fondos a disposición de cada servicio por cuotas periódicas. Estas cuotas se autorizarán mediante el Programa de Caja Mensual (artículo 23). 
Asimismo, dicha normativa establece la rendición de cuentas por quienes manejan recursos públicos (artículos 57 a 59, D.L. n. 1.263); lo mismo regula, con mayor detalle, la Ley Orgánica Constitucional de la Contraloría General de la República (artículos 85 y siguientes); QUINCUAGÉSIMO QUINTO. Que nada dice la Constitución respecto de la preparación del presupuesto. La elaboración del presupuesto y su calendario respectivo de preparación no es un asunto constitucional, pues no hay normas de la Constitución que expresamente se refieran a ella. En cambio, esto lo aborda la ley; específicamente el D.L. n. 1.263. Su artículo 13 señala que "el Ministerio de Hacienda tendrá la responsabilidad de especificar dicho calendario". Ello es complementado por el artículo 15, que dispone que a la Dirección de Presupuestos le corresponde "orientar y regular el proceso de formulación presupuestaria". De este modo, la formulación presupuestaria es un asunto que ni siquiera está regulado legalmente, menos aún en la Constitución. Mal puede, entonces, producirse una infracción constitucional en la materia; QUINCUAGÉSIMO SEXTO. Que, además, las indicaciones que se presentan durante la discusión del presupuesto, no siguen este procedimiento. Éste está diseñado para regir en la elaboración del presupuesto y así tenerlo a tiempo para ser presentado en la oportunidad que exige la Constitución, esto es "a lo menos con tres meses de anterioridad a la fecha en que debe empezar a regir" (artículo 67). Las indicaciones que presentan el Ejecutivo o los parlamentarios, durante la etapa de aprobación del presupuesto en el Congreso, no están sujetas a estos trámites que lleva a cabo la Dirección de Presupuestos. Este calendario opera antes de enviar el proyecto al Congreso; pero no una vez en trámite el proyecto de ley. Nuestro ordenamiento lo que exige es que los proyectos de ley que impliquen gastos deben contar con informe financiero (artículo 14, Ley n. 18.918). Es decir, con un documento que explique los gastos de la regulación que se propone, la fuente de los recursos que la iniciativa demande y la estimación de su posible monto; QUINCUAGÉSIMO SÉPTIMO. Que, por todas estas razones, esta Magistratura considera que debe rechazar las objeciones a las glosas 05 y 06, ya individualizadas, y así se declarará. Y TENIENDO PRESENTE lo prescrito, entre otros, en los artículos $8^{\circ}$, 19, n. 21ํ, 32, 54, 67, 69 y 93, inciso primero, n. $3^{\circ}$, e inciso cuarto, de la Constitución Política de la República y en los artículos 61 a 71 de la Ley n. 17.997, Orgánica Constitucional de este Tribunal, cuyo texto refundido, coordinado y sistematizado fue fijado por el Decreto con Fuerza de Ley n. 5, del Ministerio Secretaría General de la Presidencia, del año 2010, SE DECLARA: 1) Que se acoge el requerimiento, sólo en cuanto se declara inconstitucional la Glosa 09 de la Partida 05 (Ministerio del Interior), contenida en el proyecto de Ley de Presupuestos del Sector Público para el año 2011, la que, en consecuencia, deberá eliminarse de la Ley n. 20.481 - Ley de Presupuestos del Sector Público para el año 2011 - , publicada en el Diario Oficial en su edición de 18 de diciembre de 2010. 2) Que se rechaza el requerimiento interpuesto en cuanto impugna la constitucionalidad de las glosas 05 y 06 de la Partida 08 (Ministerio de Hacienda) del mismo proyecto de ley referido. Se previene que el Ministro señor Mario Fernández Baeza concurre a lo razonado en los considerandos DECIMOCTAVO y DECIMONOVENO del fallo y a lo declarado en el punto resolutivo $n$. 1, sin perjuicio de lo señalado en el voto disidente que ha formulado respecto del punto resolutivo n. 2. Se previene que los Ministros señora Marisol Peña Torres y Enrique Navarro Beltrán no comparten lo expresado en el considerando CUADRAGÉSIMO OCTAVO del fallo. Acordado el Capítulo III (considerandos VIGÉSIMO SEGUNDO a QUINCUAGÉSIMO SÉPTIMO) y la resolución segunda de la sentencia, que rechazan el requerimiento en lo relativo a las glosas 05 y 06 de la Partida 08 (Ministerio de Hacienda), con el voto en contra del Presidente del 
Tribunal, Ministro señor Marcelo Venegas Palacios, quien estuvo por acoger el requerimiento en su totalidad, por estimar que si bien las indicaciones parlamentarias que dieron origen a las referidas glosas fueron constitucionalmente admisibles en lo relativo a su iniciativa, ya que únicamente establecen una exigencia de información propia de la iniciativa parlamentaria, resultan, en cambio, inconstitucionales por infringir el artículo 69 de la Carta Política, al ser ajenas a las ideas matrices o fundamentales del Proyecto de Ley de Presupuestos para 2011 propuesto por el Presidente de la República al Congreso Nacional. Tiene presente para ello los motivos siguientes: $1^{\text {o }}$ Que las glosas impugnadas vienen a imponer al Poder Ejecutivo, en la ley de presupuestos, una obligación de informar sobre el "compromiso presidencial de extender el descanso de maternidad hasta los seis meses después del parto" (Glosa 05) y sobre el "compromiso presidencial de eliminar el 7\% de cotización para salud de los pensionados del país" (Glosa 06), materias ambas que precisan, para su realización, de la aprobación de reformas legislativas previas que aún no han sido propuestas al Congreso Nacional por el Presidente de la República, único constitucionalmente habilitado para hacerlo - o no - durante cualquiera de los cuatro años que dura su mandato, pues se trata de materias de su iniciativa exclusiva por incidir en la seguridad social. 20 Que, en efecto, es el propio Presidente de la República, a quien - como se dijo - corresponde la iniciativa legislativa exclusiva en la materia, quien expresa a fojas 418, en su escrito de observaciones al requerimiento, que "dichos compromisos aún no se encuentran previstos en la ley de presupuestos ni en ninguna otra norma legal sino que se trata de propósitos de llevar a cabo en el futuro, metas programáticas asumidas por el Jefe de Estado, para cumplir durante su mandato presidencial, pero que aún no poseen expresión normativa, mientras no se concreten en los respectivos proyectos de ley que establezcan los aspectos regulatorios y presupuestarios necesarios para su concreción". 3 Que corolario de lo expresado en los motivos precedentes es que, no formando parte, ni indirectamente, de la autorización de gastos prevista por el Mensaje del proyecto de Ley de Presupuestos 2011 lo relativo a los denominados "compromiso presidencial de extender el descanso de maternidad hasta los seis meses después del parto" y "compromiso presidencial de eliminar el 7\% de cotización para salud de los pensionados del país", las indicaciones que dieron origen a las cuestionadas glosas 05 y 06 de la Partida 08 (Ministerio de Hacienda), introdujeron en dicho proyecto de ley materias claramente ajenas a sus ideas matrices, en abierta contravención del artículo 69 de la Constitución, por lo que las aludidas glosas debieron, a juicio de este disidente, ser declaradas inconstitucionales por esta Magistratura Constitucional y eliminadas del texto de la Ley de Presupuestos de 2011. Acordado el punto resolutivo $n$. 2 de la sentencia con el voto en contra del Ministro señor Mario Fernández Baeza, quien estuvo por declarar inconstitucionales las tres glosas contenidas en el proyecto de Ley de Presupuestos para el año 2011 sometidas al examen de esta Magistratura y, en consecuencia, resolver la cuestión de constitucionalidad formulada al cobijo del numeral $3^{\circ}$ del artículo 93 de la Constitución, acogiendo el requerimiento de autos, sustentado en los argumentos que a continuación se exponen: 1 Que las atribuciones que la Constitución Política de la República entrega al Presidente de la República y al Congreso Nacional se encuentran nítidamente establecidas en sus Capítulos IV y V, respectivamente. 2 Que de tales atribuciones se deriva que el régimen político de Chile es presidencial, definido por la doctrina como la "amplia separación del Poder Legislativo y del Poder Ejecutivo; poder ejecutivo unitario, elección popular del presidente, imposibilidad de revocar el puesto del ejecutivo durante su gestión, imposibilidad de disolución del parlamento por parte del presidente" (Eckhard Jesse/ Dieter Nohlen: "Presidencialismo/ Sistema presidencial", en: Dieter 
Nohlen (Editor): Diccionario de Ciencia Política, Porrúa, México, 2006, tomo II). 3 Que el régimen presidencial presenta manifestaciones muy diversas en América Latina, que lo distinguen del modelo clásico norteamericano. Dos de ellas, observables en Chile, son "la primacía del Ejecutivo y la inexistencia de federalismo, es decir, las carencias en la separación y equilibrio horizontal y vertical del poder" (Dieter Nohlen/ Mario Fernández Baeza: "El Presidencialismo Latinoamericano: evolución y perspectiva", en: Dieter Nohlen y Mario Fernández Baeza (editores): El Presidencialismo Renovado. Instituciones y Cambio Político en América Latina, Ediciones Nueva Sociedad, Caracas, 1998, pp. 116-117). 4 Que el artículo 24 de la Constitución dispone en su inciso primero: "El gobierno y la administración del Estado corresponde al Presidente de la República, quien es el Jefe del Estado." Ambas funciones, verificadas copulativamente, son el fundamento del régimen presidencial chileno. 5 Que, sobre el sustento anotado, el presidencialismo chileno ha sido descrito por el tratadista Alejandro Silva Bascuñán después de analizar las atribuciones especiales del Presidente de la República dispuestas en el artículo 32 de la Constitución: "Tan vastísima acumulación de atribuciones, comprendidas en la esfera del poder estatal confiado al Presidente de la República configuran, como analizaremos más adelante, un fuerte presidencialismo, que se muestra aun más vigoroso al proyectarse en un Estado unitario. Así, pues, al Presidente corresponde tal grado de suprema potencialidad que llega a abarcar de un modo notablemente extenso e intenso, una buena porción de lo que pudiera entenderse - más allá de la simple titularidad del Poder Ejecutivo - con la dirección general de la vida política. Por lo demás, si el Presidente no puede cumplir por sí mismo todas las tareas, las cumple a través de personeros designados por él, de su exclusiva confianza, mantenidos mientras cuenten con la suya y removidos desde que son privados de ella, como son los Ministros de Estado y subsecretarios, los intendentes regionales, los gobernadores, etc. El gobierno se realiza, pues, por el Presidente, en la intensidad de su potestad, colocado en una culminación de jerarquía que subraya el vigor con que puede ejercerse" (Alejandro Silva Bascuñán: Tratado de Derecho Constitucional, Editorial Jurídica de Chile, Tomo V, 2000, p. 85-86). 6 Que, refiriéndose a la función de "administración" dispuesta en el inciso primero del artículo 24, ya citado, el mismo autor señala, citando el articulado de la Constitución con la numeración vigente en el año 2000, fecha de la publicación: "Al confiarle la administración, la Carta le entrega al Presidente la responsabilidad de su mejor organización y funcionamiento y para ello le concede iniciativa exclusiva en numerosas materias de esa índole (art. 62, incisos $3^{\circ}$ y $4^{\circ}$ ), la facultad de nombramiento de multitud de funcionarios (art. 32, ns. 6, 9, 10, 11, 12, 14 y 18), la de cuidar la recaudación de las rentas públicas y decretar su inversión (art. 32, n. 22), el manejo tributario, financiero y presupuestario (art. 64)" (Alejandro Silva Bascuñán: ob. cit., p. 86). $7^{\circ}$ Que, aun dotado constitucionalmente de una tramitación especial, el proyecto de Ley de Presupuestos no sólo está inserto en el funcionamiento del régimen presidencial señalado, sino que lo determina considerablemente. La combinación del inciso cuarto del artículo 65 con el artículo 67, especialmente sus incisos tercero y cuarto, configura de un modo concreto la primacía que el Presidente de la República dispone sobre el Parlamento y la claridad con que el texto constitucional le entrega la exclusividad de su iniciativa formal y de la fijación sustantiva de su contenido. 8 $^{\circ}$ Que, en efecto, el inciso cuarto del artículo 65 dispone: "Corresponderá al Presidente de la República la iniciativa exclusiva en los proyectos de ley que tengan relación con la alteración de la división política y administrativa del país, o con la administración financiera o presupuestaria del Estado, incluyendo las modificaciones de la Ley de Presupuestos, y con las materias señaladas en 
los números 10 y 13 del artículo 63." A su vez, el inciso tercero del artículo 67 señala: "La estimación del rendimiento de los recursos que consulta la Ley de Presupuestos y de los nuevos que establezca cualquiera otra iniciativa de ley, corresponderá exclusivamente al Presidente, previo informe de los organismos técnicos respectivos", agregándose en el inciso siguiente: "No podrá el Congreso aprobar ningún nuevo gasto con cargo a los fondos de la Nación sin que se indiquen, al mismo tiempo, las fuentes de recursos necesarios para atender dicho gasto." 9o Que las tres glosas incorporadas al proyecto de Ley de Presupuestos para el año 2011 sometidas a la consideración de esta Magistratura en sede de inconstitucionalidad, vulneran directamente las normas arriba expuestas y con ello la estructura del régimen político presidencial que la Carta establece. Ni la Cámara de Diputados ni el Congreso a través de la Comisión Mixta de Presupuestos están facultados para ejercer la iniciativa verificada a través de las indicaciones $n .8$ a la Partida 05 (Ministerio del Interior), Capítulo 01, Programa 05 (glosa 09)); y n. 29A y 29B a la Partida 08 (Ministerio de Hacienda), Capítulo 01, Programa 01 (glosas 05 y 06). Todas ellas importan un involucramiento en la administración financiera y presupuestaria del Estado y en la estimación del rendimiento de los recursos consultados en la Ley de Presupuestos. 10 Que el tenor de las citadas glosas es el siguiente: a) Glosa 09: "La Encuesta Nacional Urbana de Seguridad Ciudadana (ENUSC) que deberá realizarse anualmente por el Instituto Nacional de Estadísticas. La distribución de los fondos de seguridad ciudadana a las comunas, se hará en consideración al nivel de victimización exhibida por dicha comuna en la Encuesta Nacional Urbana de Seguridad Ciudadana realizada por el Instituto Nacional de Estadísticas (INE) en el año inmediatamente anterior", b) Glosa 05: "A más tardar el 31 de marzo de 2011 la Subsecretaría de Hacienda deberá informar a la Comisión Especial Mixta de Presupuestos sobre las líneas de acción desarrolladas, el cronograma de implementación y aspectos técnicos generales que están dentro del marco de sus competencias, relacionadas con el cumplimiento del compromiso presidencial de extender el descanso de maternidad hasta seis meses después del parto", c) Glosa 06: "A más tardar el 31 de marzo de 2011 la Subsecretaría de Hacienda deberá informar a la Comisión Especial Mixta de Presupuestos sobre las líneas de acción desarrolladas, el cronograma de su implementación y aspectos técnicos generales que estén dentro del marco de sus competencias, relacionadas con el cumplimiento del compromiso presidencial de eliminar el 7\% de cotización de salud para los pensionados del país." 11 Que, junto a la evidente contrariedad de estas glosas con las atribuciones constitucionales del Presidente de la República en materia presupuestaria, que fluyen de su sola lectura, debe agregarse una vulneración constitucional adicional, tan sustantiva como la descrita. Las glosas impugnadas no sólo lesionan la atribución presidencial de administración del Estado, sino también la muy esencial de su gobierno. 12 Que, en efecto, los denominados "compromisos presidenciales" mencionados en las glosas 05 y 06 corresponden a los programas que el gobierno conducido por el Presidente se propone realizar durante su período. Esos "compromisos" no constituyen una obligación jurídica, sino una obligación política contraída entre el Presidente y el pueblo que lo elige, derivada de dos preceptos jurídico-constitucionales, radicados en el inciso primero del artículo $5^{\circ}$ y en el primer apartado del inciso primero del artículo 26 de la Constitución. El primero señala: "La soberanía reside esencialmente en la Nación. Su ejercicio se realiza por el pueblo a través del plebiscito y de elecciones periódicas y, también, por las autoridades que esta Constitución establece. Ningún sector del pueblo ni individuo alguno puede atribuirse su ejercicio." El segundo precepto mencionado dispone: "El Presidente de la República será elegido en votación directa y por mayoría absoluta de los sufragios 
válidamente emitidos." 13 Que, según las disposiciones constitucionales referidas, es el pueblo, no el Congreso, el llamado a requerir del Presidente el cumplimiento de su programa o de los compromisos que adopte públicamente para su cumplimiento. Este carácter político y no jurídico, tampoco se altera si esos compromisos han sido formulados durante la cuenta al país del estado administrativo y político de la Nación ante el Congreso pleno, dispuesta en el último inciso del artículo 24 de la Constitución, la que también es objeto de una valoración política y en ningún caso jurídica, como es de público conocimiento año tras año después del 21 de mayo. 14 Que no procede confundir la obligación de dar cuenta del avance de un programa de gobierno como la establecida en las glosas bajo examen, con la de informar acerca de los actos y resoluciones de los órganos del Estado dispuesta en el inciso segundo del artículo $8^{\circ}$ de la Carta, como tampoco con aquellas materias objeto de fiscalización parlamentaria debidamente descritas en el número 1) del artículo 52 de la Constitución Política de la República. 15 Que, en consecuencia, otorgar conformidad constitucional al carácter legal que tendrían las obligaciones establecidas en las glosas impugnadas, significa distorsionar el deber de informar a cuyo cumplimiento se deben los órganos públicos, exceder los límites de la fiscalización de la Cámara de Diputados y arrebatar al pueblo una dimensión del derecho a ejercer la soberanía a través de las elecciones que la Constitución le otorga. Todo lo anterior en desmedro de la función de gobernar que le cabe al Presidente de la República y que no le compete al Parlamento en un régimen presidencial como el que rige en Chile. 16 Que, en suma, por las consideraciones expuestas, el requerimiento de autos debe ser acogido en todas sus partes y las glosas impugnadas eliminadas del proyecto de Ley de Presupuestos en el que se han incorporado. Acordada la decisión de declarar inconstitucional la glosa 09, Partida 05 (Ministerio del Interior), Capítulo 01 (Secretaría y Administración General), Programa 05 (Programa de Seguridad y Participación Ciudadana), contenida en el punto resolutivo $n$. 1 de la sentencia, con el voto en contra de los Ministros Hernán Vodanovic Schnake, Marisol Peña Torres, Francisco Fernández Fredes y Carlos Carmona Santander, quienes fundamentan su disidencia en las siguientes consideraciones: 1 Que, para la mayoría, la glosa 09, Partida 05 (Ministerio del Interior), Capítulo 01 (Secretaría y Administración General), Programa 05 (Programa de Seguridad y Participación Ciudadana), adolece de dos inconstitucionalidades. Por una parte, excede la idea matriz del proyecto de Ley de Presupuestos. Por la otra, afecta la iniciativa exclusiva del Presidente de la República, pues establece una obligación para un órgano de la administración del Estado, y afecta la administración financiera del Estado, porque se entromete en la distribución de recursos, habiendo sido producto de una indicación parlamentaria. I. LA GLOSA IMPUGNADA. 2 Que, para un adecuado análisis de estas objeciones, es necesario examinar previamente la glosa que se impugna. Ésta tiene dos partes. En la primera, se señala que una encuesta ("la Encuesta Nacional Urbana de Seguridad Ciudadana") debe realizarse "anualmente por el Instituto Nacional de Estadísticas". En la segunda, se indica que para la distribución de fondos de seguridad ciudadana entre las comunas del país, se debe tener en consideración "al nivel de victimización exhibido por dicha comuna en la Encuesta Nacional Urbana de Seguridad Ciudadana, realizada por el Instituto Nacional de Estadísticas (INE) en el año inmediatamente anterior". 3 Que cabe señalar que la Encuesta Nacional Urbana de Seguridad Ciudadana (ENUSC) y el hecho de que la haga el INE no son una creación de la glosa que se impugna. En primer lugar, porque tal encuesta se viene realizando desde hace seis años mediante un convenio entre el INE y el Ministerio del Interior. De ello da cuenta el informe sobre la ENUSC 2009, que se acompaña al escrito de observaciones que hizo llegar la Presidenta de la Cámara 
de Diputados con ocasión del presente requerimiento, el que rola a fojas 867 y siguientes. 4. Que, en segundo lugar, esta encuesta se enmarca dentro del Programa de Seguridad y Participación Ciudadana del Ministerio del Interior, que año a año regula la Ley de Presupuestos. Este programa tiene su reglamento en el D.S. n. 382, de Interior, del año 2006. En esta normativa se contemplan "estudios para el seguimiento y apoyo del Programa de Seguridad y Participación Ciudadana, con una asignación de recursos destinados al financiamiento de encuestas y otros estudios orientados a apoyar científicamente la intervención social y la elaboración de diagnósticos y Planes Comunales de Seguridad Pública" (artículo 3). 5 Que, en tercer lugar, a esta encuesta se refiere la Glosa 08 de la misma Partida 05, en que se inserta la glosa impugnada. No es, por tanto, atribuible a la glosa impugnada su existencia. 6\% Que, por otra parte, la segunda parte de la glosa establece un criterio orientador para la distribución de los recursos entre las comunas. No establece un mandato. Señala que la distribución de los fondos de seguridad ciudadana a las comunas "se hará en consideración al nivel de victimización exhibido por dicha encuesta... en el año inmediatamente anterior". II. LA GLOSA NO EXCEDE LA IDEA MATRIZ. 7ㅇ Que el primer reproche que se formula a la glosa es que excede la idea matriz. Estos disidentes no comparten esa afirmación. En primer lugar, porque en el propio mensaje con que el Ejecutivo envió el proyecto de Ley de Presupuestos al Congreso Nacional, se pone como una de sus prioridades "la seguridad ciudadana" (pág. 1); agregando más adelante que "con este proyecto de presupuesto vamos a fortalecer el piso de las seguridades de nuestras familias" (pág. 2). En uno de los apartados del proyecto, titulado "Un proyecto de presupuesto para una sociedad de seguridades", se indica que "en materia de combate a la delincuencia y al narcotráfico, el proyecto de ley de presupuestos de Carabineros de Chile permite tener durante el próximo año más de 4.000 nuevos efectivos policiales, de los 10.000 que comprometimos para nuestro período" (pág. 3). 8 Que, en segundo lugar, no hay que olvidar que la glosa se incorpora en el Programa 05 del Capítulo 01 de la Partida 05, titulado justamente "Programa de Seguridad y Participación Ciudadana". No se advierte cómo, entonces, puede estar fuera de la idea matriz una glosa inserta dentro de dicho programa. 9 Que, en tercer lugar, existen ocho glosas que anteceden a la impugnada, que tienen que ver con el Programa de Seguridad y Participación Ciudadana. En todas ellas se detallan obligaciones de distinta naturaleza para el Ministerio del Interior. En nada difieren estas obligaciones de las que establece la glosa. 10 $Q u e$, en cuarto lugar, durante la discusión parlamentaria el Ejecutivo, en el Senado, formuló una indicación (la 190), que reemplazaba la glosa impugnada y que fue rechazada. Había dos diferencias básicas entre esta propuesta y la glosa impugnada. Por una parte, señalaba que la encuesta la debía realizar una empresa o institución externa vía licitación. Por la otra, establecía la distribución de los recursos de seguridad ciudadana mediante una serie de indicadores. Para el Ejecutivo, entonces, la idea de la encuesta y de los criterios de distribución no estaba ajena a la idea matriz. No se explica de otro modo que haya presentado una indicación en tal sentido. III. LA GLOSA NO AFECTA LA INICIATIVA EXCLUSIVA DE LEY DEL PRESIDENTE DE LA REPÚBLICA. 11 Que, para el voto de mayoría, la glosa invadió en un doble sentido la facultad exclusiva del Presidente en materia de ley. De un lado, al establecer una nueva atribución para el INE en orden a realizar anualmente una encuesta. Del otro, al inmiscuirse en la administración de fondos, estableciendo un mecanismo de distribución. a. No establece una nueva obligación. 12 Que, para estos disidentes, tal objeción no es admisible. En primer lugar, debemos reiterar que la Encuesta Nacional Urbana de Seguridad Ciudadana no es una creación de la glosa. Ésta se viene realizando hace seis años por el INE, mediante convenios con el Ministerio del Interior. 
Además, la glosa anterior a la impugnada se refiere expresamente a ella, al establecer un criterio para la distribución de fondos del programa Barrio en Paz. 13 Que, en segundo lugar, la glosa tampoco entrega al INE la facultad para hacer encuestas. Este servicio público tiene, en el artículo $2^{\circ}$, letra d), de la Ley $n$. 17.374, la facultad de "efectuar periódicamente encuestas destinadas a actualizar las bases de los diferentes índices, en especial los del costo de vida". No es la glosa la que confiere la facultad de realizar una encuesta. 14 Que, en tercer lugar, tampoco la glosa impugnada establece la obligación de realizar esta encuesta anualmente, pues esto lo hace la glosa 08 ya referida, al establecer la victimización de los habitantes como criterio objetivo y público del Programa Barrios en Paz, en base a los resultados de la ENUSC "del año inmediatamente anterior".

Esta glosa fue incorporada como indicación del Ejecutivo (la 189) durante la tramitación de la Ley de Presupuestos en el Senado. b. No implica inmiscuirse en la administración financiera. 15 Que tampoco para estos disidentes la glosa 09 implica inmiscuirse en la administración financiera del Estado. En primer lugar, porque no establece una distribución de fondos. Sólo consagra un criterio para hacerlo. La glosa dice "la distribución.... se hará en consideración". La expresión "consideración" es, en su sentido natural y obvio, la acción de "estimar", "ponderar", "evaluar con atención y cuidado". La facultad de distribución de los fondos sigue siendo resorte del Ejecutivo. 16. Que, en segundo lugar, el criterio que se establece no es el único que puede considerar el Ejecutivo; éste puede ponderar otros. En ninguna parte la glosa emplea expresiones como "exclusivamente", "únicamente", que connotarían la idea de criterio único. Además, esta interpretación es consistente con el reglamento del Programa de Seguridad y Participación Ciudadana (D.S. n. 382/2006, Interior), el que establece que la determinación de las comunas del Programa se realizará tomando en cuenta otros criterios. Su artículo $4^{\circ}$ señala que ello se hará "evaluando las características sociales y delictuales de las comunas, conforme a un Índice de Vulnerabilidad Social Delictual elaborado por el Ministerio del Interior, el que considerará variables e indicadores relacionados con factores de riesgos presentes en cada comuna y será ponderado con criterios relativos a población comunal, tasa de denuncias por delitos de mayor connotación social y, según corresponda, tasa de victimización". Como se observa, la "victimización" no es un criterio innovador, pues se encontraba presente en esta regulación reglamentaria. 17 $Q u e$, en tercer lugar, la glosa presupuestaria no modifica la facultad que establece el artículo 22 de la Ley Orgánica Constitucional de Bases Generales de la Administración del Estado, que expresamente entrega a los ministerios la facultad de "asignar recursos". Por lo mismo, el Ministerio del Interior sigue conservando esta potestad.18 ${ }^{\circ}$ Que, en cuarto lugar, lo anterior es consecuente con lo establecido en el mismo Reglamento recién señalado, el cual deja a salvo la facultad de administración financiera del Ministerio del Interior, es decir, del Ejecutivo. En efecto, por una parte, porque establece que la selección y ejecución de los proyectos financiados por los recursos del Programa "deberán ajustarse a las orientaciones técnicas y administrativas que serán elaboradas y aprobadas por el Ministerio del Interior". Por la otra, porque establece que los fondos que asigne la Ley de Presupuestos "podrán ser invertidos año a año, en las áreas o subprogramas señalados en el artículo $3^{\circ}$ del presente decreto, en los porcentajes y montos que determine el Ministerio del Interior". Dichas áreas o subprogramas son el pago de honorarios de los secretarios técnicos comunales de seguridad pública; el apoyo a los municipios para asignar recursos para la calidad de la gestión municipal en materia de seguridad pública; la capacitación y difusión de planes de capacitación; gastos de administración; el fondo destinado a apoyar la estrategia de seguridad pública en materia de prevención social 
y situacional, rehabilitación y asistencia a víctimas. IV. LA GLOSA IMPUGNADA NO AFECTA LOS PRINCIPIOS DE EFICIENCIA Y EFICACIA. TAMPOCO EL ARTÍCULO 19 N. 21 DE LA CONSTITUCIÓN. 19 Que el Presidente de la República, en su escrito de observaciones, agrega dos nuevas objeciones a la glosa en examen. Por una parte, afirma que se afecta el principio de eficiencia y eficacia como parte de la probidad administrativa. Por la otra, sostiene que entregar esta encuesta al INE afecta el artículo 19 n. 21 de la Constitución, porque permite al INE desarrollar una actividad económica privada, ajena a su actual función. 20 Que no compartimos la primera objeción, pues, en primer lugar, los principios de eficacia y eficiencia sólo tienen consagración legal (artículos 3o, 11 y 62, n. 8, de la Ley Orgánica Constitucional de Bases Generales de la Administración del Estado). La Constitución utiliza otros parámetros para evaluar la gestión administrativa. Así, considera la legalidad (artículos 7o; 20; 27; 52, n. 2, letras a) y b); 98), la arbitrariedad (artículos 19, ns. 2으. $20^{\circ}$ y 22ㅇ), el respeto a los derechos (artículos 5o; 20; 38), la conveniencia u oportunidad de una decisión (artículo 52, n. 1). Pero no consagra dichos principios. En este sentido, una eventual vulneración de ellos es un problema de legalidad, no de constitucionalidad. En segundo lugar, controlar la eficacia y la eficiencia implica evaluar si se han obtenido resultados o se han empleado óptimamente los recursos asignados. Ello es propio de un control de mérito, ajeno a las atribuciones de esta Magistratura. Dicho control incluso es ajeno a las atribuciones de la Contraloría (artículo 21 b), Ley Orgánica Constitucional de la Contraloría General de la República) y recae más bien en los órganos internos de la propia administración, vía control jerárquico (artículo 11, Ley Orgánica Constitucional de Bases Generales de la Administración del Estado) o vía verificación y evaluación del cumplimiento de fines y la obtención de metas (artículo 52, D.L. n. 1.263). En el presupuesto es esencial distinguir el control de legalidad de su ejecución del control de la política económica que se pretende llevar a cabo con los recursos que involucra el presupuesto. Este último es un control que escapa a los organismos de control diseñados por nuestro sistema. 21 Que, en relación a la eventual vulneración del artículo 19 n. 21ํㅡ. tampoco la compartimos. En primer lugar, porque, como ya hemos señalado, el INE tiene la atribución otorgada por ley para realizar encuestas. De acuerdo a la Constitución, ése es el principal parámetro para evaluar si la actuación de un órgano de la administración del Estado es o no legítima (artículo 65, inciso cuarto, n. 2, y artículo $7^{\circ}$ ). En segundo lugar, la realización de encuestas no es un monopolio privado ni público. Por lo mismo, el legislador puede perfectamente autorizar a un servicio para realizar encuestas. En tercer lugar, los servicios pueden cumplir sus tareas con sus propios medios o recursos, o recurrir a los privados. En tal sentido, el INE puede encargar, mediante un contrato a una empresa privada, la realización de una encuesta. De este modo, la oposición tajante entre la actividad estatal y la privada, tal como es formulada en el escrito del Presidente, no es tal.

Tribunal Constitucional

Sentencia Rol 1867

Fecha: 30.12 .10

\section{COLÔMBIA}

DIREITO SANITÁRIO CONSUMERISTA. Fundamentos da decisão. Competência. A Sala de Revisão da Corte Constitucional é competente para proferir sentença em ação de tutela, com base nos artigos 86, 2 e 241, da 
Constituição, em conformidade com os artigos 31 a 36 do Decreto 2591 de 1991. Problema Jurídico. Neste caso, cabe ao Conselho determinar se uma instituição médica pré-paga viola os direitos de uma mulher à saúde e à vida digna ao negar a realização do procedimento cirúrgico "mamoplastia redutora", afirmando que este se encontra excluído do contrato de prestação de serviços de saúde. III. DECISÃO. RESOLVE: Primeiro. REVOGAR as sentenças proferidas pelo Quinto Tribunal Penal Municipal com Funções de Controle de Garantias de Manizales em 04 de agosto de 2010, e pelo Segundo Tribunal Penal do Circuito de Manizales, em 08 de setembro de 2010, em relação ao caso de referência. PROTEGER os direitos fundamentais à saúde e à vida digna de Catalina Pérez López. Segundo. ORDENAR a Coomeva Medicina Pré paga S.A. que, no prazo de 8 (oito) dias contados da notificação apresente providência, programe e realize para sua afiliada Catalina Pérez López procedimento "mamoplastia conectora e AP de todo o tecido ressecado", nos termos prescritos pelo médico assistente designado. Notifique-se, comunique-se, cumpra-se e publique-se na Gazeta da Corte Constitucional.

\section{Corte Constitucional}

Sentença: T-134/11 (Referencia: expediente T-2.826.450)

Relator: Luis Ernesto Vargas Silva.

Julgamento: 3.3.11

La Sala Novena de Revisión de la Corte Constitucional, integrada por los magistrados María Victoria Calle Correa, Mauricio González Cuervo y Luis Ernesto Vargas Silva en ejercicio de sus competencias constitucionales y legales, ha proferido la siguiente.

SENTENCIA. Dentro del trámite de revisión de los fallos dictados por el Juzgado Quinto Penal Municipal con funciones de Control de Garantías de Manizales y el Juzgado Segundo Penal del Circuito de Manizales, en el asunto de la referencia. I.

ANTECEDENTES. De los hechos y la demanda. 1. Catalina Pérez López presentó acción de tutela contra Coomeva Medicina Prepagada, por considerar que la entidad vulneró sus derechos fundamentales a la salud y a la vida digna, con base en los siguientes hechos: 1.1. Manifiesta que fue atendida por los médicos de Coomeva Medicina Prepagada, quienes le diagnosticaron hipertrofia mamaria, dorsalgia y quistes de mama bilaterales. 1.2. Señala que, en razón de ello, su médico tratante determinó que debía someterse a la cirugía de mamoplastia de reducción. 1.3. El 19 de julio de 2010, la entidad accionada negó la prestación del servicio aduciendo que la mamoplastia está expresamente excluida del plan de medicina prepagada, tal como lo establece la Cláusula Sexta del contrato de prestación de servicios de salud que regula las "exclusiones para todos los programas". 1.4. La accionante relata que la patología que padece le impide llevar una vida tranquila pues sufre constantemente de fuertes dolores en el cuello y dorsalgia, que le impiden desarrollar su profesión como arquitecta. 2. La demanda de tutela fue admitida por el Juzgado Quinto Penal Municipal con Funciones de Control de Garantías de Manizales el 22 de julio de 2010. Intervención de la parte demandada. 3. María Eugenia López Martínez, directora de Coomeva Medicina Prepagada - Oficina Manizales, constató que la accionante se encuentra afiliada en medicina prepagada desde el 30 de marzo de 1998. No obstante, manifestó 
que la entidad no puede autorizar la realización de cirugías de mamoplastia puesto que de acuerdo con la cláusula sexta del contrato de prestación de servicios de salud, dicho procedimiento se encuentra expresamente excluido. En este sentido, señaló que la entidad que representa no vulneró los derechos fundamentales de la accionante pues se ha sujetado en todo al contrato pactado libre y autónomamente por ella. De los fallos de tutela. 4. Mediante providencia del 4 de agosto de 2010, el Juzgado Quinto Penal Municipal con Funciones de Control de Garantías de Manizales negó el amparo solicitado. Señaló que la regla establecida por la Corte Constitucional en la materia consiste en que la tutela no es procedente para resolver las controversias derivadas del contrato de prestación de servicios adicionales de salud, excepto cuando ellas comprometan la satisfacción de los derechos fundamentales de los accionantes. Ello ocurre, por ejemplo, cuando se niega la prestación de un servicio que no ha sido excluido expresamente del contrato, o cuando la cláusula de exclusiones es ambigua. En el caso de la accionante, el juez encontró que la exclusión de la mamoplastia es expresa y evidente y, por tanto, la entidad no está obligada a realizar el procedimiento. No obstante, advirtió que la accionante puede controvertir ante la jurisdicción ordinaria el contrato que suscribió, así como acudir a la EPS para solicitar el tratamiento de su patología. De la impugnación y el fallo de segunda instancia. 5. El 9 de agosto de 2010 la accionante apeló la decisión del Juzgado Quinto Penal Municipal con Funciones de Control de Garantías de Manizales sin añadir nuevos argumentos. 6. El Juez Segundo Penal del Circuito de Manizales (Caldas), en sentencia proferida el 8 de septiembre de 2010, confirmó la decisión de primera instancia. Argumentó que el contrato de medicina prepagada se rige por el principio de la autonomía de la voluntad y que la intervención del juez constitucional debe limitarse a las situaciones en las cuales los derechos fundamentales del afiliado se encuentran gravemente vulnerados o amenazados. De acuerdo con el juez, esto no ocurre en el presente caso pues la accionante pactó libremente con la empresa de medicina prepagada que el procedimiento objeto de discusión sería excluido del plan, y no se observa que esta decisión constituya una vulneración del derecho a la salud de la actora, quien puede solicitar la autorización de la cirugía a la EPS. Pruebas relevantes que obran en el expediente. 7. Copia de la historia clínica de la accionante. 8. Orden médica expedida el 15 de julio de 2010, en la que se indica que la accionante requiere "mamoplastia conectora y A.P de todo el tejido resecado". 9. Formato de negación del procedimiento firmado por David Horacio Posada el 15 de julio de 2010, en el que se indica que la mamoplastia no es un servicio cubierto por el plan de medicina prepagada. Se indica que la disposición que respalda la decisión es la Cláusula Sexta del Contrato de Prestación de Servicios de Salud Coomeva Medicina Prepagada S.A, relativa a las exclusiones para todos los programas. 10. Copia del contrato de prestación de servicios de salud Coomeva Medicina Prepagada S.A. II. FUNDAMENTOS DE LA DECISIÓN. Competencia. Esta Sala de Revisión de la Corte Constitucional es competente para proferir sentencia dentro de la acción de tutela de la referencia, con fundamento en los artículos 86 inciso 2 y 241 numeral 9 de la Constitución Política, en concordancia con los artículos 31 a 36 del Decreto 2591 de 1991. Problema jurídico. En el presente asunto corresponde a la Sala establecer si una entidad de medicina prepagada vulnera los derechos de una mujer a la salud y a la vida digna al negarle la realización del procedimiento quirúrgico "mamoplastia de reducción", alegando que este se encuentra excluido del contrato de prestación de servicios de salud. Con este fin, la Sala reiterará las reglas relativas a la procedencia de la acción de tutela para resolver conflictos 
derivados de contratos de medicina prepagada. Abordará luego las reglas que ha establecido la Corte en relación con el alcance y las limitaciones de los contratos de medicina prepagada a la luz del principio de buena fe y del derecho a la salud $y$, finalmente, se pronunciará sobre el caso concreto. 1. Procedencia de la acción de tutela para resolver controversias derivadas de contratos de medicina prepagada. Reiteración de jurisprudencia. El servicio de medicina prepagada es una modalidad dentro de los planes adicionales de salud establecidos en la Ley 100 de 1993, que pueden adquirir los afiliados al régimen contributivo, con el fin de obtener beneficios opcionales como la atención en eventos no incluidos en el POS, o condiciones diferentes o adicionales de hostelería y tecnología. De acuerdo con la normatividad, las empresas de medicina prepagada gestionan y brindan atención médica y servicios cubiertos por un plan de salud preestablecido, recibiendo como contraprestación el pago de un precio regular previamente acordado. La Corte ha establecido con claridad que la relación surgida entre el usuario y la empresa de medicina prepagada es eminentemente de derecho privado, y que la prestación de los servicios contratados se rige de manera estricta por el contenido de las cláusulas del contrato suscrito. Pero junto a esta naturaleza contractual, ha advertido esta Corporación que el objeto del negocio es la prestación del servicio público de salud y, por lo tanto, ha reconocido que la ejecución de los planes de medicina prepagada puede involucrar la efectividad de los derechos fundamentales del afiliado, tales como la vida, la integridad física y la salud. Debido a ello, la Corte ha reiterado que el escenario propicio para resolver las controversias que se derivan del alcance o del cumplimiento de las cláusulas pactadas libremente por las partes es la jurisdicción ordinaria y que, como regla general, la acción de tutela es improcedente. Sin embargo, cuando la empresa hace uso de su posición dominante y vulnera el derecho a la salud u otros derechos fundamentales de los afiliados al plan de medicina prepagada, o cuando se acredita la inminencia de un perjuicio irremediable, la vía ordinaria no es idónea ni eficaz $y$, en consecuencia, la acción de tutela se torna procedente. 2. Límites de los planes adicionales de salud en aplicación del principio de buena fe contractual y la protección del derecho a la salud. La salud ha sido definida como un derecho fundamental que consiste en la posibilidad de alcanzar el nivel más alto de bienestar físico, mental y social dentro de lo posible para una persona. La prestación de los servicios tendientes a satisfacer esta garantía constitucional debe responder a las características de calidad, eficacia y oportunidad. Adicionalmente, las entidades prestadoras del servicio no pueden desconocer el principio de integralidad, conforme al cual no es posible fraccionar los tratamientos cuando ello implica un obstáculo insalvable para la atención de la patología del paciente; ni el principio de continuidad, de acuerdo con el cual el servicio de salud no puede ser interrumpido injustificadamente antes de la recuperación o estabilización del paciente. Los parámetros mencionados han sido dirigidos principalmente a la prestación de los servicios en el marco del plan obligatorio de salud, bien sea como parte del régimen contributivo o del subsidiado. Sin embargo, esta Corporación ha hecho una aplicación analógica de dichos principios a la medicina prepagada, en cuanto cabe, otorgándoles un contenido propio. Para hacerlo, ha tenido en cuenta que los contratos de prestación de servicios adicionales de salud se ejecutan en virtud de una relación contractual de adhesión, bilateral y onerosa, vigilada por la Superintendencia de Salud, y que su propósito no es reemplazar totalmente a las instituciones que prestan servicios integrales y obligatorios de salud, como son las entidades del régimen contributivo. En este sentido, la Corte ha determinado que 
para salvaguardar el derecho a la salud de los usuarios de todos los planes adicionales de salud debe atenderse a los siguientes criterios: 2.1. En la formación del contrato. (i) Los contratos para la prestación de servicios adicionales de salud no pueden ser celebrados ni renovados con personas que no se encuentren afiliadas al POS. Así lo establece el artículo 20 del Decreto 806 de 1998. La omisión de esta disposición obliga a la empresa a responder por la atención integral en salud de su afiliado sin consideración a las limitaciones pactadas pues, de no hacerlo, la persona podría verse desprotegida ante las amenazas a la vida y a la salud no cubiertas por el plan de medicina prepagada. (ii) Antes de suscribir el contrato de medicina prepagada, las empresas deben realizar exámenes médicos lo suficientemente rigurosos. Esto tiene como propósito (1) detectar los padecimientos de salud que constituyan preexistencias; (2) determinar su exclusión expresa de la cobertura del contrato; y (3) permitir que el usuario decida si bajo estas condiciones - es decir, la exclusión de las preexistencias del contrato - persiste su intención de celebrar el convenio. El examen médico otorga seguridad jurídica a la relación contractual. Por tanto, las enfermedades no diagnosticadas como resultado de dicho examen, no podrán ser consideradas preexistencias, y deberán ser tratadas $y$ atendidas médicamente por la entidad. (iii) El acuerdo de voluntades mediante el cual se celebra el contrato de prestación de servicios adicionales de salud debe fundarse tanto en el principio de buena fe como en la confianza mutua entre contratantes. En la sentencia SU-039 de 1998, la Corte precisó que: "Comoquiera que la celebración de un contrato de esa clase se desarrolla dentro del campo de los negocios jurídicos en la forma de un acuerdo de voluntades para producir efectos jurídicos, lo que supone un desarrollo bajo la vigencia de los principios generales que los informan, como ocurre con el principio de la buena fe que no sólo nutre estos actos sino el ordenamiento jurídico en general y el cual obtiene reconocimiento expreso constitucional en el artículo 83 de la Carta Política de 1991, como rector de las actuaciones entre los particulares, significa que, desde su inicio y especialmente durante su ejecución, al incorporarse el valor ético de la confianza mutua en los contratos de medicina prepagada, se exige un comportamiento de las partes que permita brindar certeza y seguridad jurídica respecto del cumplimiento de los pactos convenidos y la satisfacción de las prestaciones acordadas." Además, en tanto que en el contrato de adhesión de los planes de medicina prepagada la parte débil es el usuario de los servicios de salud, ha dicho la Corte que las dudas en la interpretación de las cláusulas del contrato que impliquen un posible vulneración del derecho a la salud, deben resolverse a favor del afiliado, sin perjuicio de que en situaciones concretas pueda demostrarse su mala fe. 2.2. Durante la ejecución del contrato. (iv) Las empresas prestadoras de servicios adicionales de salud deben dar cumplimiento estricto a todas las cláusulas del contrato suscrito con el usuario. Las empresas de medicina prepagada deben emplear la debida diligencia en la prestación de la atención médica que el afiliado requiera, a fin de que recupere o mejore su estado de salud, o prevenga la aparición de nuevos padecimientos. Para ello, deben actuar dentro del marco normativo que regula la materia. (v) Durante la ejecución del contrato de medicina prepagada la empresa no puede modificar unilateralmente las condiciones para su cumplimiento. La compañía de medicina prepagada no puede negarse al cumplimiento de una obligación inicialmente contraída, cuando en su momento no se dijo nada en el contrato, frente a su exclusión o garantía. En los casos de duda respecto de la aplicación de esta subregla, la Corte ha determinado que debe presumirse la buena fe del paciente al momento de suscribir el contrato y que, en consecuencia, le corresponde a la empresa probar que el 
contratante tenía conocimiento de su enfermedad al momento de obligarse. (vi) La empresa de medicina prepagada no puede desplazar a la EPS su responsabilidad en la atención médica de las enfermedades cubiertas en el contrato. Si el contrato de medicina prepagada prevé servicios incluidos en el POS, la empresa no puede negarse a proporcionarlos argumentando que ellos pueden ser prestados por la EPS. En este sentido, el artículo 18 del Decreto 806 de 1998 establece que el usuario de un Plan Adicional de Salud puede elegir libre y espontáneamente si utiliza el POS o el plan adicional en el momento de requerir atención médica, y advierte que "las entidades no podrán condicionar su acceso a la previa utilización del otro plan". 2.3. Especificamente para la aplicación de exclusiones. (vii) Se entienden excluidos del objeto contractual, únicamente aquellos padecimientos del usuario considerados como preexistencias, cuando previa, expresa y taxativamente se encuentren mencionadas en las cláusulas de la convención o en sus anexos en relación específica con el afiliado. La Corte ha establecido que las "preexistencias" son enfermedades o afecciones que aquejan al paciente al momento de suscribir el contrato y, por ello, no se incluyen como objeto de los servicios prepagados. Estas excepciones a la cobertura no pueden estar señaladas en forma genérica en el contrato. La compañía de medicina prepagada tiene la obligación de determinar, de acuerdo a los exámenes previos, "cuáles enfermedades congénitas y cuáles preexistencias no serán atendidas en relación con cada usuario" (subrayado dentro del texto). Toda vez que esta constituye una carga de la empresa y no del usuario, cuando una enfermedad adquirida previamente a la firma del contrato no haya sido incorporada de manera concreta en el contrato o sus anexos como preexistencia o como exclusión, esta no puede ser oponible al afiliado como excusa para negarse a la prestación de un servicio. (viii) Los contratos de prestación de servicios de salud que contengan exclusiones que exceptúen de manera general o imprecisa ciertas enfermedades o la prestación de determinados servicios de salud, o que lo hagan de manera ambigua, no son oponibles al usuario. Debido a que las exclusiones constituyen limitaciones al contrato de prestación de servicios de salud, su interpretación y aplicación debe ser restrictiva y respetar el principio de buena fe contractual. Por ello, la cláusula de exclusiones dentro de un contrato de medicina prepagada no puede exceptuar de forma genérica toda una rama de enfermedades, tratamientos o estudios para su diagnóstico, o dejar de señalar con suficiente precisión y claro lenguaje a cuáles hace referencia, de suerte que el usuario pueda decidir si adhiere o no al contrato. Es necesario precisar que esta regla relativa a las exclusiones genéricas (viii) se diferencia de la anterior que aborda a la exclusión de las enfermedades o afecciones que pudieron originarse o desarrollarse antes de la firma del contrato (vii). Dado que las preexistencias debieron ser detectadas por la compañía de medicina prepagada mediante los exámenes médicos previos y el examen de los antecedentes del contratante, las exclusiones derivadas de ellas deben pactarse en relación con cada usuario, es decir, teniendo en cuenta su situación particular. No son eficaces las cláusulas contenidas en los formatos de contrato que excluyen preexistencias de manera genérica, aun cuando ellos hayan sido objeto de revisión por parte de la Superintendencia de Salud, puesto que el tomador del contrato de medicina prepagada que tiene una preexistencia posee unas características particulares, con base en las cuales tanto el usuario como la entidad pactan la prestación de los servicios de salud. En virtud de la buena fe contractual, cuando la compañía de medicina prepagada no establece expresamente cuáles son los exámenes, tratamientos o suministros que están excluidos, pudiendo hacerlo, se 
entiende que el afiliado toma la decisión de pagar el plan adicional de salud con base en el convencimiento fundado de que la compañía deliberadamente los incluyó dentro del contrato. Cuando la enfermedad, afección o patología no puede ser determinada con el mismo nivel de suficiencia como el esperado en las preexistencias, es improbable que la entidad conozca cuáles serán los servicios que el paciente requerirá y que, en virtud de la autonomía de su voluntad, no está dispuesto a cubrir. En estos casos, entonces, no es indispensable que las exclusiones se pacten en relación con cada uno de los usuarios. Lo que es absolutamente necesario atendiendo al carácter taxativo de las cláusulas restrictivas, es que estas se establezcan de manera manifiesta, que no contengan expresiones genéricas, que no excluyan una rama completa de enfermedades o un conjunto impreciso de exámenes diagnósticos, y que la forma en que están estipuladas no se preste para interpretaciones simultáneas respecto de su inclusión y sustracción, pues ello impide al usuario conocer de forma suficiente el tipo de procedimientos cubiertos por el plan antes de adherirse a él. El carácter genérico, impreciso o ambiguo de las cláusulas de exclusión atenta contra la buena fe contractual pues esconde información relevante que será determinante para quien suscribirá el plan adicional, y se convierte en una excusa por medio de la cual se evita por todos los medios el cumplimiento del objeto principal del contrato, en desmedro de la salud y la integridad física del paciente. Por ello, la Corte ha indicado que "la responsabilidad frente a la prestación de medicamentos y procedimientos médicos que se requieran para el tratamiento de una enfermedad que no se encuentre expresa y claramente determinada en el contrato de medicina prepagada recae sobre la entidad que presta este servicio". Este último criterio ha sido empleado por la Corte en sentencias precedentes, respecto de distintos tipos de planes adicionales de salud. Así, por ejemplo, en la sentencia T-171 de 2003, la Corte ordenó a una compañía de seguros practicar la cirugía de banda gástrica requerida por la accionante teniendo en cuenta que el contrato excluía de forma general los tratamientos para la obesidad, y de acuerdo con los conceptos médicos allegados al expediente, se pudo establecer que la "obesidad mórbida tiene una condición patológica que permite distinguirla de la simple obesidad". La Corte encontró que esta condición de particularidad hace que dicha cirugía "no pueda entenderse comprendida en la exclusión genérica de los tratamientos por obesidad". En otro caso resuelto en la sentencia T-699/04, una mujer desarrolló luego de la realización de los exámenes diagnósticos iniciales, una enfermedad de carácter congénito y requería para su tratamiento la realización de varios procedimientos quirúrgicos. En la cláusula de limitaciones contractuales se pactó que la empresa de medicina prepagada no asumiría el costo de "las enfermedades o malformaciones congénitas". No obstante, la Corte encontró que esta cláusula era demasiado genérica y que, por lo tanto, no era oponible a la contratante pues su aplicación conllevaba a la interrupción del servicio respecto de un amplia e indeterminable cantidad de patologías. En la sentencia T-795 de 2008, la Corte ordenó a una empresa de medicina prepagada practicar al afiliado el examen PET CT (tomografía de emisión de positrones combinada con tomografía computarizada) con la regularidad que se requiriera pues, aunque no se trataba de un procedimiento tendiente a diagnosticar el estado de una patología preexistente, se encontró que el contrato no indicaba que este tipo de exámenes estuvieran exceptuados y, por el contrario, indicó que la cláusula de coberturas incluía todos los servicios de "medicina nuclear". Por su parte, en la sentencia T-158 de 2010 la Corte negó la autorización del reemplazo total de rodilla izquierda mediante implantación de una prótesis anatómica, 
exigido por el accionante a su compañía de seguros, pues determinó que el suministro de prótesis se encontraba excluido expresamente de la póliza, y que la cláusula señalaba con claridad la cuantía del reconocimiento y el valor tope asegurado para la ocurrencia de esa clase de siniestros. Encontrándose precisa y expresa la exclusión, la Sala concluyó que el valor del suministro requerido excedía por mucho la limitación contractual $y$, por tanto, no declaró que la entidad accionada vulnerara los derechos del paciente. Igualmente, en la sentencia T-584 de 2010, la accionante solicitó la realización de una mamoplastia de reducción ordenada por su médico tratante dentro del plan de medicina prepagada. Si bien la Corte falló a favor de la paciente por cuanto no se encontraba vinculada al plan obligatorio de salud del régimen contributivo, sí estableció con claridad que no correspondía en principio a la empresa de medicina prepagada cubrir el valor de la cirugía toda vez que la cláusula de exclusión era clara y precisa. En suma, la extensión de la cobertura de los servicios prepagados de salud dependerá de los términos en los cuales se pacta el contrato, comprendidos a la luz del principio de buena fe contractual, de protección del usuario como parte débil del contrato, y del derecho a la salud. Por esta razón, cuando la interpretación o ejecución del clausulado que rige la relación contractual involucre derechos fundamentales, corresponde a los jueces constitucionales establecer su preciso alcance a la luz de los principios previamente establecidos. 3. El caso concreto. La controversia planteada en el presente caso surge por la negativa de Coomeva Medicina Prepagada de autorizar el procedimiento "mamoplastia de reducción" prescrito por el médico tratante a la afiliada Catalina Pérez López, aduciendo que conforme a la cláusula sexta "exclusiones para todos los programas", el plan adicional de salud no cubre la cirugía "mamoplastia". Antes de abordar el fondo del asunto, advierte la Sala que los jueces de instancia en este proceso declararon improcedente la acción de tutela argumentando que el problema suscitado alrededor de la exclusión de procedimientos quirúrgicos en el marco de un plan de medicina prepagada es un asunto contractual que no involucra la garantía de ningún derecho fundamental, y que por ello, la actuación del juez constitucional es improcedente. Para la Sala, aunque es acertado considerar que la realización de la mamoplastia depende de la interpretación que se haga de la cláusula sexta del contrato de medicina prepagada, también lo es que la decisión que se adopte involucra el derecho a la salud de la parte débil del contrato, comoquiera que el procedimiento le fue ordenado por su médico tratante, luego de que se llevaran a cabo todos los exámenes diagnósticos que arrojaron como resultado que la accionante padece de "hipertrofia mamaria, dorsalgia y quistes de mama bilaterales". El problema contractual se convierte entonces en una amenaza a su salud y a la calidad de vida, de modo que la acción de tutela se torna procedente. Ahora bien, el argumento central expuesto por los jueces de instancia y por la entidad accionada para sostener la improcedencia de la acción consiste en que, en el caso sub examine, la exclusión del procedimiento "mamoplastia" se encuentra estipulada de forma manifiesta, clara y específica en la cláusula sexta del contrato. Dada esta situación, según ellos, debe concluirse que la compañía de medicina prepagada no vulneró el derecho de la accionante quien puede acudir a la EPS y solicitar la realización del tratamiento. A este razonamiento, la actora opone lo establecido en la sentencia T-471 de 2000 en la que se ordenó la autorización de una mamoplastia reductora, pese a que la empresa de medicina prepagada utilizó el mismo término para excluir el procedimiento de la cobertura, aduciendo que no lo hizo de manera particular y específica respecto de la afiliada. Conforme a lo establecido en las consideraciones anteriores, esta Sala 
estima que no era necesario que la entidad de medicina prepagada pactara la exclusión de la mamoplastia en relación concreta con la accionante puesto que, conforme al acervo probatorio existente, no se hallan elementos para afirmar que la enfermedad para la cual se requiere el procedimiento podía ser considerada preexistente al contrato o podía ser detectada mediante los exámenes previos de ingreso. Por esta razón, no es preciso seguir de forma estricta lo establecido en la sentencia T-471 de 2000, que desestimó la exclusión hecha por la entidad de medicina prepagada. A juicio de esta Corporación, lo que corresponde hacer es examinar si la cláusula sexta del contrato de prestación de servicios de salud, en cuanto señala que la mamoplastia está excluida de todos los programas, es genérica, poco precisa, o de interpretación ambigua, al punto que desconozca el principio de buena fe contractual. Al respecto, tal como lo señaló la Corte en la sentencia T-584 de 2010, la Sala halla la formulación de la disposición que excluye la "mamoplastia" lo suficientemente precisa y específica respecto de aquellos eventos en los que el paciente no tiene una condición preexistente. En efecto, se trata de una expresión técnica que no incluye dentro de sí múltiples procedimientos que disten de ser asociables a un solo tipo de patologías, así como tampoco agrupa procedimientos quirúrgicos de niveles altamente desiguales en complejidad, riesgo y costo. Pese a ello, la Sala no puede afirmar lo mismo de la univocidad de la intención de exclusión del mencionado procedimiento al hacer una lectura sistemática del contrato de medicina prepagada. Pues mientras que la cláusula sexta del formato excluye expresa y claramente la "mamoplastia" para todos los programas, en la cláusula cuarta relativa a servicios y cubrimientos, numeral 3.1, la entidad accionada manifiesta que "cubrirá a partir del primer día del décimo tercer (13) mes de vigencia ininterrumpida del contrato, contada desde la fecha de iniciación del servicio para cada Usuario: (...) cirugía mamaria" (negrilla fuera del texto). De manera general, la cirugía mamaria y la mamoplastia pueden ser consideradas como términos que pertenecen a la misma categoría de procedimientos quirúrgicos, ya que ambos tienen como fin intervenir el tejido mamario de las mujeres, aumentando o disminuyendo su volumen con fines estéticos o funcionales. Así las cosas, la mención simultánea en la cláusula de cobertura y en la de exclusión no permite determinar con claridad cuál fue la intención real de la parte que redactó la forma del contrato. Esto significa que la cláusula de exclusión de la mamoplastia tiene un carácter ambiguo y que, por lo tanto, no le es oponible a la accionante. El tratamiento que se hace de este tipo de procedimientos quirúrgicos relacionados con la modificación de los senos en el contrato de prestación de servicios de salud desarrollado por la entidad accionante tiene como efecto desconocer la buena fe contractual, pues impide que se determine con claridad cuáles son las exclusiones de los servicios de salud del programa de medicina prepagada antes de suscribir el plan. No puede afirmarse por ello que la accionante se adhirió al contrato contando para ello con información suficiente y transparente. En consecuencia, la entidad accionada debe asumir la responsabilidad sobre la prestación del servicio quirúrgico requerido por la accionante. Ello es posible puesto que las cirugías mamarias están cubiertas por el plan de medicina prepagada a los usuarios que iniciaron el servicio por lo menos trece meses antes de la solicitud de la cirugía. En este caso, Coomeva Medicina Prepagada certificó que la accionante se encuentra activa dentro del plan de medicina prepagada desde 1998, esto es, desde hace más de diez años. Teniendo en cuenta lo anterior, esta Sala revocará las sentencias proferidas por el Juzgado Quinto Penal Municipal con Funciones de Control de Garantías de Manizales y el Juzgado Segundo Penal del Circuito de Manizales. En su lugar, concederá el 
amparo del derecho a la salud y a la vida digna de Catalina Pérez López y, en atención a ello, ordenará a Coomeva Medicina Prepagada que, dentro del término de ocho (8) días contados a partir de la notificación de la presente providencia, programe y practique a la accionante el procedimiento "mamoplastia conectora y $A$. $P$ de todo el tejido resecado" en los términos ordenados por el médico tratante adscrito a la entidad. III. DECISIÓN. Con fundamento en las consideraciones expuestas en precedencia, la Sala Novena de Revisión de la Corte Constitucional, administrando justicia en nombre del pueblo y por mandato de la Constitución, RESUELVE: Primero. REVOCAR las sentencias proferidas por el Juzgado Quinto Penal Municipal con Funciones de Control de Garantías de Manizales el 4 de agosto de 2010, y por el Juzgado Segundo Penal del Circuito de Manizales el 8 de septiembre de 2010, en relación con el asunto de la referencia. En su lugar, TUTELAR los derechos fundamentales a la salud y a la vida digna de Catalina Pérez López. Segundo. En consecuencia, ORDENAR a Coomeva Medicina Prepagada S.A que, en el término de ocho (8) días contados a partir de la notificación de la presente providencia, programe y practique a su afiliada Catalina López Pérez el procedimiento "mamoplastia conectora y A. $P$ de todo el tejido resecado", en los términos ordenados por el médico tratante adscrito a la entidad. Tercero. Por Secretaría General, LÍBRENSE las comunicaciones de que trata el artículo 36 del Decreto 2591 de 1991. Notifíquese, comuníquese, cúmplase e insértese en la Gaceta de la Corte Constitucional.

Corte Constitucional

Sentencia T-134/11 (Referencia: expediente T-2.826.450)

Magistrado Ponente: Luis Ernesto Vargas Silva.

Fecha: 3.3.11

DIREITO SANITÁRIO CONSUMERISTA. ANTECEDENTES. Em 18 de agosto de 2010 Cesar Augusto Arango Mejía interpôs ação de tutela em favor de seu filho, o menor Sérgio Arango Jiménez, em defesa dos seus direitos fundamentais à dignidade humana, a saúde e à seguridade social, em conexão com o direito a vida, contra Coomeva EPS. Com o objetivo de ordenar a continuação do tratamento que a criança vem recebendo e com os médicos que o estão tratando. V. DECISÃO. Em face do exposto, RESOLVEU. Primeiro: REVOGAR a sentença proferida pelo Segundo Tribunal Penal Municipal de Controle das Garantias de Manizales, datado de 01 de Setembro de 2010 única instância - , pelo que negou amparo pelo autor contra Coomeva EPS. Segundo. PROTEGER o direito à saúde do menor Sergio Arango Jiménez. Terceiro. ORDENAR a Coomeva EPS que dentro de quarenta e oito (48) horas após a notificação da presente decisão autoriza sessões neuropsicologia para que Maria Leonor Molina e Juan Bernardo Zuluaga (médicos) prescreveram para o menor Sergio Arango Jiménez, continuem a ser realizadas na cidade de Manizales, no mínimo, nas mesmas condições e com os especialistas que estavam desenvolvendo o tratamento, enquanto isso seja possível. Notificado, comunicado, publicado no Diário do Tribunal Constitucional e à execução. Notifique-se, comunique-se e publique-se na Gazeta da Corte Constitucional e cumpra-se. 
Corte Constitucional

Sentença: T-096/11 (Referência: expediente T-2824666)

Relator: Juan Carlos Henao Pérez

Julgamento: 22.2.11

La Sala Tercera de Revisión de la Corte Constitucional, integrada por los Magistrados Gabriel Eduardo Mendoza Martelo, Jorge Iván Palacio Palacio y Juan Carlos Henao Pérez, quien la preside, en ejercicio de sus competencias constitucionales y legales, ha proferido la siguiente. SENTENCIA. En el proceso de revisión del fallo proferido por el Juzgado Segundo Penal Municipal con Función de Control de Garantías de Manizales, de fecha 01 de septiembre de 2010 - única instancia -, por el cual se negó el amparo solicitado por el accionante en contra de Coomeva EPS. I. ANTECEDENTES. El día 18 de agosto de 2010 Cesar Augusto Arango Mejía interpuso acción de tutela en nombre de su hijo, el menor Sergio Arango Jiménez, en defensa de sus derechos fundamentales a la dignidad humana, la salud y la seguridad social, en conexidad con el derecho a la vida, contra Coomeva EPS. Lo anterior, con el fin de que se ordene la continuidad del tratamiento que el niño ha venido recibiendo y con los doctores que lo han venido tratando. La acción de tutela se fundamenta en los siguientes: 1. Hechos. 1.1. El niño Sergio Arango Jiménez se encuentra afiliado a Coomeva EPS como beneficiario. 1.2. El menor padece problemas neurológicos, hiperactividad y problemas de atención por lo que ha sido atendido en el Hospital Infantil de Manizales por los doctores María Leonor Molina y Juan Bernardo Zuluaga, quienes han obtenido resultados positivos gracias al tratamiento que le han proporcionado al niño durante seis meses. 1.3. Como parte del tratamiento, los médicos prescribieron algunas sesiones de neuropsicología que fueron autorizadas en principio por la EPS. Sin embargo, ésta última negó con posterioridad la autorización de las mismas, razón por la cual la madre del menor interpuso acción de tutela. 1.4. El Juzgado Sexto Penal con Función de Control y Garantías de Manizales tuteló los derechos fundamentales del menor y ordenó a la EPS autorizar la valoración neuropsicológica y garantizar el tratamiento integral que necesita, con la posibilidad de recobrar ante el Fosyga los costos que comporta dicha valoración. 1.5. Proferida la sentencia anterior la EPS autorizó todos los servicios pero indicó que las terapias neuropsicológicas serían autorizadas sólo en la ciudad de Pereira, de manera que el tratamiento tendría que iniciarse de nuevo en dicha ciudad, con lo cual se pierden, según el demandante, los avances logrados en la salud del menor. 1.6. Por lo anterior, el accionante solicitó por escrito que el tratamiento se continuara prestando en la ciudad de Manizales y con los mismos profesionales que lo venían haciendo. Explicó los motivos por los cuales el traslado no sería conveniente para su hijo, principalmente porque el niño ha logrado entablar una buena relación con los médicos de la ciudad de Manizales y ha logrado importantes avances en su tratamiento, que se perderían si lo inicia de nuevo en otra ciudad en la que no reside y con otros profesionales. 1.7. La EPS Coomeva respondió negativamente a la solicitud e indicó que el tratamiento se había autorizado solo en la ciudad de Pereira. 1.8. Por todo lo anterior, el padre del menor considera que Coomeva EPS ha vulnerado nuevamente los derechos de su hijo a la salud, a la vida digna y a la seguridad social al pretender obligarlos a desplazarse hasta la ciudad de Pereira para que el niño reciba el tratamiento que requiere. 2. Documentos relevantes cuyas copias obran dentro del expediente. 1. Fotocopia de la cédula de ciudadanía del accionante César Augusto Arango Mejía. 2. Fotocopia de comunicación enviada 
por la madre del menor el 12 de julio de 2010 a la EPS tratante en la que solicita que le entreguen por escrito la comunicación en la que se indica que el tratamiento del niño no fue autorizado. 3. Respuesta definitiva elaborada por Coomeva EPS, para el caso de Sergio Arango Jiménez, en la que se indica que no fue posible autorizar las sesiones de clínica atencional en el Hospital Infantil de Manizales para el menor. Informa la EPS que el mencionado servicio fue autorizado para ser prestado en la ciudad de Pereira a través de la IPS que Coomeva ha contratado para tal fin. 4. Fotocopia del concepto del psicólogo Juan Bernardo Zuluaga, quien venía tratando al niño desde febrero de 2010 hasta antes de que la EPS tomara la decisión de no seguirle prestando el servicio, quien considera que los niños que sufren de estas patologías son altamente susceptibles a los cambios de ambiente, tales como traslado de domicilio, de profesores, de colegio o de los profesionales que llevan el proceso. Por esta razón, no recomienda el cambio de institución ni de programa. 5. Registro civil de nacimiento del niño Sergio Arango Jiménez en el que consta que el accionante es su padre y que el niño tiene siete años de edad. 6. Oficio proveniente del Hospital Infantil Universitario mediante el cual, el psicólogo Juan Bernardo Zuluaga, psicólogo del equipo de salud mental del Hospital Infantil Universitario y participante del programa Clínica Atencional que atiende al niño Sergio Arango Jiménez, informó que todos los niños que asisten a dicho programa con diagnóstico de déficit de atención con hiperactividad, requieren tanto de medicamentos (ritalina) como de una evaluación neuropsicológica, psicológica y psiquiátrica. Además, deben iniciar un proceso de intervención con estrategias de modificación de conducta y de control de su atención y de su hiperactividad. Indicó además que lo más recomendable es que los niños que ya iniciaron un proceso con determinados profesionales continúen con los mismos y no sufran cambios abruptos. Dichos cambios generan altibajos académicos y comportamentales además de interferencias en el contexto familiar, social y escolar. 7. Fotocopia de la acción de tutela interpuesta por la señora Claudia Patricia Jiménez Quintero en representación de su hijo menor de edad Sergio Arango Jiménez, en contra de Coomeva EPS. Allí manifestó la accionante que a su hijo menor de edad se le diagnosticó trastorno de conducta, hiperactividad y déficit de atención, que ha sido tratado en la clínica atencional del Hospital Infantil donde le prescribieron, como parte del tratamiento, algunas sesiones de neuropsicología. Indicó que de dichas sesiones, las primeras le fueron autorizadas pero, posteriormente, la EPS tratante las negó por considerar que se trata de un tratamiento que no está incluido en el Plan Obligatorio de Salud - POS - y que el padecimiento del niño es de naturaleza educativa y no terapéutica. Indica la peticionaria que las mencionadas sesiones tienen que llevarse a cabo más o menos durante 6 años y que cada una de ellas tiene un costo aproximado de 300.000 pesos que ella no puede sufragar. 8. Fotocopia de la sentencia del Juzgado Sexto Penal Municipal con Función de Control de Garantías de Manizales, Caldas del 27 de agosto de 2009, por la cual se resolvió la tutela mencionada anteriormente. Durante el curso de dicho proceso se obtuvo el concepto de dos de los profesionales que habían venido teniendo contacto con el menor. La psicóloga especialista en neuropsicopedagogía afirmó que la no realización del tratamiento en cuestión atentaría contra la vida en condiciones dignas del menor ya que permanentemente seguiría estando expuesto al rechazo y seguiría siendo maltratado por parte de las personas que lo rodean, a causa de su comportamiento disruptivo. Manifestó además que, hasta ahora no se conoce ningún otro procedimiento que esté cubierto por el POS y que pueda ser efectivo para el menor. Por su parte, el doctor Luis Guillermo Valencia señaló que el estado de salud 
del menor le impedía tener un mejor rendimiento académico y mejores relaciones sociales y que el tratamiento en cuestión no se encuentra cubierto por el POS y no existe ningún otro que pueda reemplazarlo. En esta ocasión consideró el Juzgado que lo primero que debía tenerse en cuenta era el hecho de que se trataba del caso de un menor de edad, lo que lo situaba en una situación de debilidad manifiesta dado su alto grado de vulnerabilidad e indefensión en frente del conglomerado social. Manifestó que cuando se trata de menores de edad no hay duda que la tendencia es la de proteger sus derechos siempre que esto sea posible. Mencionó además que la sentencia $T-760$ de 2008 reiteró que en tratándose de menores de edad, así el servicio que estos requieran no esté incluido en el POS, éste debe prestarse porque la salud en los niños es un derecho fundamental. Teniendo en cuenta además que en el caso bajo estudio el menor no solo se encontraba en estado de debilidad por ser menor de edad sino además por su estado de discapacidad que implicaba la necesidad de recibir un tratamiento eficiente, integral y óptimo para mejorar sus condiciones de vida, tal como lo ha reiterado la jurisprudencia. En segundo lugar, se hizo un análisis del tema referente al derecho al diagnóstico. Consideró que el simple hecho de pertenecer al sistema general de seguridad social en salud entraña la potestad de tener todos los servicios. De esta manera, manifestó el juez constitucional que lo que se requería en ese momento era realizar todas las valoraciones que conllevaran a un diagnóstico claro para establecer definitivamente la necesidad del tratamiento solicitado. Invocó así mismo, lo que ha dicho la Corte Constitucional con respecto al derecho al diagnóstico: dentro del sistema general de seguridad social en salud se encuentra incluido el derecho a un efectivo diagnóstico, el cual le concede al paciente la prerrogativa de exigirle a las entidades prestadoras de salud la realización de los procedimientos que resulten precisos con el objetivo de establecer la naturaleza de la dolencia, para que, de esa manera, el médico cuente con un panorama de plena certeza sobre la patología y determine las prescripciones más adecuadas para la recuperación de la salud del afectado. El derecho a un diagnóstico, se configura como un supuesto necesario para garantizar al paciente la consecución de los siguientes objetivos: - Establecer con precisión la patología que padece. - Determinar con el máximo grado de certeza permitido por la ciencia y la tecnología, el tratamiento médico que asegure de forma más eficiente el derecho al más alto nivel posible de salud. - Iniciar dicho tratamiento con la prontitud requerida por la enfermedad sufrida por el paciente. De esta manera, cuando se hace nugatorio el derecho a un diagnóstico, se desconocen garantías de rango constitucional como la vida y la salud. Pasa luego el juez a analizar el tema del suministro de servicios médicos excluidos del Plan Obligatorio de Salud. Al respecto señala que en muchas ocasiones la Corte Constitucional ha inaplicado la reglamentación que excluye la prestación de un servicio o la realización de un tratamiento, para ordenar su práctica o suministro. Cuando la salud de las personas se encuentra grave y directamente comprometida dichas disposiciones pueden inaplicarse si se cumplen los siguientes requisitos: que la falta del tratamiento excluido amenace los derechos constitucionales fundamentales a la vida o a la integridad personal del interesado; que se trate de un tratamiento que no pueda ser sustituido por uno de los contemplados en el Plan Obligatorio de Salud o, que pudiendo sustituirse, el sustituto no obtenga el mismo nivel de efectividad; que el paciente realmente no pueda sufragar el costo del tratamiento requerido y que no pueda acceder a él por ningún otro sistema o plan de salud; que el tratamiento haya sido prescrito por un médico adscrito a la Empresa Promotora de Salud a la cual esté afiliado el demandante. Si todos estos 
requisitos se verifican la EPS tendrá que proporcionar el tratamiento y conserva la facultad de pedir el reembolso de sus costos al Fondo de Solidaridad y Garantía Fosyga - Se analiza también el punto del carácter integral de la prestación del servicio de salud: la atención en salud debe ser integral y por ello comprende todo cuidado necesario para el restablecimiento de la salud del paciente. De conformidad con el principio de integralidad, las entidades que hacen parte del sistema general de seguridad social en salud deben prestar un tratamiento integral a sus pacientes. Frente al caso concreto, indicó que está demostrado que el menor Sergio Arango Jiménez es menor de edad y tiene una discapacidad, circunstancias estas que lo convierten en un sujeto de especial protección. Así mismo, el servicio solicitado no es un capricho de la demandante, de hecho, los especialistas tratantes son quienes han recomendado la valoración neuropsicológica. La posición de la EPS demandada es una posición poco garantista que desconoce que la patología del menor afecta su desempeño como individuo, teniendo en cuenta además que pese a que el tratamiento en cuestión no está en el POS, es (i) necesario para preservar la salud del menor, (ii) no puede ser sustituido por otro, (iii) los padres no pueden sufragarlo y (iv) fue ordenado por los médicos tratantes. Por dichas razones, el juez procedió a conceder la tutela ordenando para el menor la prestación de un tratamiento integral que incluyera todo lo que se considerara necesario luego de ser completada la valoración neuropsicológica; $y$, ordenó al Fosyga el reintegro de las sumas que para estos fines tuviese que cancelar la EPS. Aclaró además el juez que el argumento de la EPS según el cual el tratamiento solicitado era un procedimiento netamente educativo y no relacionado con la salud, no resulta válido; los artículos 2 y 3 del Decreto 366 de 2009 define al estudiante discapacitado y endilga obligaciones a los entes territoriales al respecto y no excluye ningún tratamiento. 9. Declaración del señor César Augusto Arango Mejía en la que indica que el tratamiento que venía recibiendo su hijo fue suspendido por parte de la EPS Coomeva quien manifestó que el servicio no podía seguir prestándose en la ciudad de Manizales, donde reside el menor, sino que se prestaría de allí en adelante en la ciudad de Pereira. Indicó que se comunicó con los médicos del niño quienes le indicaron que iniciar de nuevo el tratamiento en otra ciudad sería contraproducente para el menor, razón por la cual el accionante tuvo que instaurar nuevamente acción de tutela contra la EPS. Manifestó además que tanto él como su esposa colaboran para el sustento del hogar, siendo su salario de $\$ 792.000$ y el de su esposa, el salario mínimo por lo cual no cuentan con los medios económicos para sufragar el tratamiento de su hijo (\$300.000 por sesión) ni para trasladarse de ciudad para que éste pueda recibirlo, teniendo en cuenta que con dicho dinero deben sufragar gastos de primera necesidad. 10. Se encuentra por último en el expediente un oficio de la doctora María Leonor Molina, médica psicóloga especialista en neuropsicopedagogía, en el que se establece que el procedimiento prescrito al paciente tiene sus bases en terapia cognitiva, manejo del autocontrol corporal y conductal, trabajo específico de terapia ocupacional y fonoaudiología, y que, paralelo a esto se realiza también tratamiento con los padres para que ellos aprendan a tratar al niño en la manera adecuada. Indica la doctora que la urgencia de la continuidad en el programa es necesaria dados los progresos que ha presentado el menor, y que iniciar el tratamiento en otra institución implicaría volver a empezar todo el proceso, lo cual sería perjudicial para la salud del niño quien además tiene unas particulares condiciones emocionales y de adaptación. 3. Contestación de la Accionada. Una vez notificada de la existencia de la presente acción de tutela, Coomeva EPS procedió a hacer las 
siguientes precisiones: en primer lugar manifestó que el menor Sergio Arango Jiménez se encontraba afiliado en calidad de beneficiario en el régimen contributivo desde el 01 de diciembre de 2005, y que al momento de la negativa de la prestación del servicio en la ciudad de Manizales contaba con 242 semanas cotizadas y era atendido en dicha ciudad donde se ubicaba además su residencia. En segundo lugar, indicó que como beneficiario del régimen ha tenido derecho a recibir los beneficios del sistema general de seguridad social en salud contemplado en el Plan Obligatorio de Salud - POS -, a cargo de la EPS. En tercer lugar, Coomeva EPS adujo que estaba dando cumplimiento al fallo del Juzgado Sexto Penal Municipal con Función de Control de Garantías de Manizales del 27 de agosto de 2009, en el sentido de garantizar las terapias neuropsicológicas requeridas para el manejo de la patología del menor con la doctora Yamile Bocanegra en la ciudad de Pereira. De esta manera reiteró que ha cumplido con brindarle el tratamiento al menor a través de una de sus IPS adscritas en la ciudad de Pereira. II. SENTENCIAS OBJETO DE REVISIÓN. 1. Sentencia de Única Instancia. El Juzgado Segundo Penal Municipal con Función de Control de Garantías de Manizales, Caldas, procedió a decidir el presente asunto mediante sentencia del 01 de septiembre de 2010. Consideró el juez que estaba claro que la intención del accionante era que su hijo siguiera recibiendo el tratamiento que venía recibiendo y con los mismos doctores que lo venían tratando en la ciudad de Manizales, por considerar que un cambio repentino en el mismo podría generar efectos negativos en la salud del niño y haría que se perdiera el progreso que hasta el momento se había logrado. Sin embargo, indicó que, a su juicio, la acción de tutela era improcedente por haberse instaurado ya una acción de tutela por los mismos hechos, acción que culminó en la protección de los derechos del menor. Consideró que en el presente caso había identidad de partes y de objeto y decidió denegar la acción de tutela por improcedente. III. ACTUACIONES SURTIDAS EN SEDE DE REVISIÓN. 1. EI magistrado sustanciador, mediante auto de pruebas del veintisiete (27) de enero de 2011, ordenó a Coomeva EPS que dentro de las veinticuatro (24) horas siguientes a la notificación del mismo informara cuáles fueron las razones para remitir al menor Sergio Arango Jiménez a la ciudad de Pereira para recibir el tratamiento que su patología requiere, cuando su lugar de residencia y donde ha venido recibiendo tratamiento es la ciudad de Manizales. Así mismo, ordenó al señor César Augusto Arango Mejía que dentro de las veinticuatro (24) horas siguientes a la notificación del auto, informara cuál era la situación actual de su hijo y, si éste se encontraba o no recibiendo algún tratamiento. En caso positivo, aclarara qué tipo de tratamiento y en qué institución. 2. Coomeva EPS procedió a dar respuesta a la anterior solicitud mediante escrito del 3 de febrero de 2011, en el que manifestó que la información solicitada se refiere a un "paciente al que inicialmente se le ofreció cobertura de servicio en el hospital infantil de la ciudad de Manizales. Posteriormente, y por disponibilidad de la red en la ciudad de Pereira, y contrato vigente en esta ciudad, se direccionó caso a la ciudad de Pereira. Se aclara que el fallo no menciona taxativamente ni ordena entrega de servicio en una ciudad específica". Por último indicó que "la EPS no direcciona los casos a ciudad de Manizales por cuanto no ha existido contrato directo para la especialidad remitida, ni para el tratamiento ordenado al menor". 3. Por su parte, el señor César Augusto Arango Mejía informó que en un principio, y hasta mayo de 2010 las terapias fueron autorizadas en la ciudad de Manizales y que a partir de dicho mes no se volvieron a aprobar. Ratificó que a raíz de esta situación se interpuso acción de tutela y el juez constitucional ordenó a la EPS prestar el tratamiento 
completo, ante lo cual la EPS decidió prestarlo pero en una ciudad distinta a la de residencia del menor donde hasta ahora se había venido tratando, razón por la cual, ante este hecho nuevo se interpuso la acción de tutela bajo estudio. IV. CONSIDERACIONES y fundamentos. 1. Competencia. Esta Sala es competente para revisar las decisiones proferidas dentro de la Acción de Tutela de la referencia, con fundamento en los artículos 86 y 241 numeral 9 de la Constitución Política. El expediente fue seleccionado para su revisión el día 14 de octubre de 2010 por la Sala de Selección número Diez. 2. Presentación del caso y planteamiento del problema jurídico. 2.1. El niño Sergio Arango Jiménez está afiliado a Coomeva EPS como beneficiario de su madre. El menor padece problemas neurológicos, hiperactividad y problemas de atención por lo que ha sido atendido en el Hospital Infantil de Manizales por los doctores María Leonor Molina y Juan Bernardo Zuluaga, quienes han obtenido resultados positivos gracias al tratamiento que le han proporcionado durante seis meses. Como parte del tratamiento, los médicos tratantes prescribieron sesiones de neuropsicología que, en principio, fueron autorizadas. Sin embargo, posteriormente ésta última negó la autorización de las mismas, razón por la cual la madre del menor interpuso acción de tutela. El Juzgado Sexto Penal con Función de Control y Garantías de Manizales tuteló los derechos fundamentales del menor y ordenó a Coomeva EPS autorizar la valoración neuropsicológica del mismo y garantizar el tratamiento integral que necesita el menor, con la posibilidad de recobrar ante el Fosyga los costos que lo anterior comportara. Proferida la sentencia la EPS autorizó todos los servicios pero indicó que las terapias neuropsicológicas serían autorizadas en la ciudad de Pereira, de manera que el tratamiento tendría que iniciarse de nuevo en dicha ciudad, perdiéndose, según el demandante, los avances que ya se habían logrado en la salud del menor. Por lo anterior, el accionante solicitó por escrito a la EPS que se siguiera tratando al niño en la ciudad de Manizales y a través de los mismos profesionales que lo venían haciendo. Explicó los motivos por los cuales el traslado no sería conveniente para su hijo, principalmente por haber logrado entablar una buena relación con los médicos de la ciudad de Manizales e importantes avances en su tratamiento, los cuales se perderían de iniciarse de nuevo en otra ciudad y con otros profesionales. La EPS Coomeva respondió negativamente a su solicitud e indicó que el tratamiento se había autorizado sólo en la ciudad de Pereira. El padre del menor considera que Coomeva EPS ha vulnerado nuevamente los derechos de su hijo a la salud, a la vida digna y a la seguridad social al pretender obligarlos a desplazarse hasta la ciudad de Pereira para que el niño reciba el tratamiento que requiere. Una vez notificada de la existencia de la presente acción de tutela, Coomeva EPS precisó que el menor Sergio Arango Jiménez se encontraba afiliado en calidad de beneficiario en el régimen contributivo desde el 01 de diciembre de 2005, y que al momento de la negativa de la prestación del servicio en la ciudad de Manizales contaba con 242 semanas cotizadas y era atendido en dicha ciudad donde se ubicaba además su residencia. Indicó, que como beneficiario del régimen ha tenido derecho a recibir los beneficios del sistema general de seguridad social en salud contemplado en el Plan Obligatorio de Salud POS - a cargo de la EPS. Adujo además que estaba dando cumplimiento al fallo del Juzgado Sexto Penal Municipal con Función de Control de Garantías de Manizales del 27 de agosto de 2009, en el sentido de garantizar las terapias neuropsicológicas requeridas para el manejo de la patología del menor con la doctora Yamile Bocanegra en la ciudad de Pereira. El Juzgado Segundo Penal Municipal con Función de Control de Garantías de Manizales, Caldas, procedió a decidir el presente asunto mediante 
sentencia del 01 de septiembre de 2010. Consideró el juez que estaba claro que la intención del accionante era que su hijo siguiera recibiendo el tratamiento que venía recibiendo y con los mismos doctores que lo venían tratando en la ciudad de Manizales, ya que un cambio repentino en el mismo podría generar efectos negativos en la salud del niño y haría que se perdiera el progreso que hasta el momento se había logrado. Sin embargo, consideró que la acción de tutela era improcedente por haberse instaurado ya en otra oportunidad una acción de tutela por los mismos hechos, acción que culminó en la protección de los derechos del menor, por lo que denegó la acción de tutela por improcedente. En sede de revisión, el magistrado sustanciador ordenó a Coomeva EPS que informara cuáles fueron las razones para remitir al menor Sergio Arango Jiménez a la ciudad de Pereira para recibir el tratamiento que su patología requiere, a lo que la accionada respondió que lo había remitido a dicha ciudad por tener allí la facilidad de prestar el servicio, pero en ningún momento probó que la hubiera dejado de tener en la ciudad de Manizales. No encuentra la Sala razón para que la EPS haga la afirmación anterior por cuanto en el expediente está probado que en un principio el tratamiento requerido fue autorizado y otorgado en la ciudad de Manizales, y, no se prueba que el contrato con la IPS de Manizales se haya dado por terminado. Así mismo, ordenó al señor César Augusto Arango Mejía que informara cuál era la situación actual de su hijo y si éste se encontraba o no recibiendo algún tratamiento, y, en caso positivo, que aclarara qué tipo de tratamiento y en qué institución; ante lo que el accionante hizo un recuento de todos los hechos que se han presentado en el caso concreto y reiteró que la no prestación del servicio en la ciudad de Manizales afecta gravemente la salud de su hijo. 2.2. Teniendo en cuenta todo lo anterior, el problema jurídico a resolver es si Coomeva EPS ha vulnerado los derechos a la salud, a la vida digna y a la seguridad social del menor Sergio Arango Jiménez, al ordenar que las sesiones de neuropsicología que requiere le sean prestadas en la ciudad de Pereira y no en la ciudad de Manizales donde reside y donde ha sido tratado hasta la fecha. Para resolver dicho problema se desarrollarán los siguientes temas: $i$. La existencia de un hecho nuevo implica la procedencia de una nueva acción de tutela sin que haya temeridad. ii. El carácter fundamental del derecho a la seguridad social y a la salud. iii. Análisis del caso concreto. i. Actuación temeraria. La existencia de un hecho nuevo implica la procedencia de una nueva acción de tutela sin que haya temeridad. 1. El artículo 38 del Decreto-ley 2591 de 1991 regula el tema de la temeridad y al respecto señala: "Cuando, sin motivo expresamente justificado, la misma acción de tutela sea presentada por la misma persona o su representante ante varios jueces o tribunales, se rechazarán o decidirán desfavorablemente todas las solicitudes." 2. De esta manera, la jurisprudencia constitucional ha señalado que la "temeridad" se ha entendido "como la actitud de quien demanda o ejerce el derecho de contradicción a sabiendas de que carece de razones para hacerlo, o asume actitudes dilatorias con el fin de entorpecer el desarrollo ordenado y ágil del proceso". Del mismo modo, la Corte Constitucional ha sostenido que la actuación temeraria es aquella que supone una "actitud torticera", que "delata un propósito desleal de obtener la satisfacción del interés individual a toda costa", que expresa un abuso del derecho porque "deliberadamente y sin tener razón, de mala fe se instaura la acción", o, finalmente que constituye "un asalto inescrupuloso a la buena fe de los administradores de justicia". Ahora bien, para declarar la configuración de la temeridad el juez constitucional debe verificar el cumplimiento de tres requisitos fundamentales: (i) Que exista identidad en los procesos, lo cual implica que el proceso fallado con antelación 
y el proceso propuesto al juez, a su vez, tienen una "triple identidad", esto es, en ambos se identifican las mismas partes, la misma solicitud y las mismas razones de dicha solicitud. (ii) Que el caso no sea un caso excepcional explícitamente determinado por la ley o la jurisprudencia, como uno que no configura temeridad. Es decir, casos frente a los cuales se ha autorizado la procedencia del proceso propuesto a pesar de existir un fallo con el cual guarda identidad. (iii) Que de presentarse una demanda de tutela que pretenda ser distinta a una anterior con la que guarda identidad, a partir de una argumentación diferente, se demuestre por parte del juez que el proceso propuesto y la tutela anterior se reducen a unas mismas partes, una misma solicitud y unas mismas razones. 3. En cuanto al primer requisito para la configuración de la temeridad, el juez de tutela debe establecer la existencia de características comunes en los dos procesos, tales como: (i) La identidad de partes, es decir, que ambas acciones de tutela se dirijan contra el mismo demandado y, a su vez, sean propuestas por el mismo sujeto en su condición de persona natural, ya sea obrando a nombre propio o a través de apoderado judicial, o por la misma persona jurídica a través de cualquiera de sus representantes legales. (ii) la identidad de causa petendi, es decir, que el ejercicio repetido de la acción se fundamente en unos mismos hechos que le sirvan de causa; (iii) la identidad de objeto, esto es, que las demandas busquen la satisfacción de una misma pretensión tutelar o sobre todo el amparo de un mismo derecho fundamental. Si el juez constitucional comprueba que en las dos acciones de tutela presentadas existe identidad de partes, identidad de hechos e identidad de objeto, tendrá que declarar que existe temeridad y abstenerse de proferir un pronunciamiento de fondo, puesto que el asunto materia de litigio ya fue fallado y dicho fallo ha hecho tránsito a cosa juzgada. De este modo, en materia constitucional cuando se configura triple identidad entre la demanda de tutela y una o varias demandas pendientes de fallo, implica la declaración de improcedencia de la misma, al igual que cuando lo anterior se da respecto de una acción de tutela ya fallada. En conclusión, el juez de tutela debe verificar si la demanda de tutela propuesta en su despacho guarda identidad de partes, de causa o hechos que la motivan y de objeto o pretensión, con otra tutela anteriormente decidida o pendiente de resolución. 4. Sin embargo, la Corte Constitucional ha establecido algunas excepciones a los eventos anteriores, es decir, ha definido que, en ciertos casos, aun si se configuran los requisitos mencionados, no hay temeridad. De hecho, la Corte ha desarrollado varios criterios al respecto. Se ha sostenido que la declaratoria de improcedencia de la tutela por temeridad debe analizarse desde una perspectiva distinta a la meramente procedimental, cuando el ejercicio simultáneo o repetido de la acción de tutela se funda en: (i) La condición de ignorancia o indefensión del actor, propia de aquellas situaciones en que los individuos obran por miedo insuperable o por la necesidad extrema de defender un derecho y no por mala fe. (ii) El asesoramiento errado de los profesionales del derecho. (iii) La consideración de eventos nuevos que aparecieron con posterioridad a la interposición de la acción o que se omitieron en el trámite de la misma, o cualquier otra situación que no se haya tomado como base para decidir la(s) tutela(s) anterior(es) que implique la necesidad de proteger los derechos fundamentales del demandante. (iv) Se puede interponer una nueva acción de amparo cuando la Corte Constitucional profiere una sentencia de unificación, cuyos efectos son extensivos a un grupo de personas que se consideran en igualdad de condiciones, incluso si con anterioridad a dicha sentencia presentaron acción de tutela por los mismos hechos y con la misma pretensión. (v) Por último, la Corte ha detectado situaciones en las que la vulneración se configura 
después de interpuesta o fallada la acción de tutela, pues surgen eventos cuya consecuencia vulnera derechos fundamentales en una misma situación de hecho en la que se había determinado que la tutela no era procedente. Esto sucede por ejemplo cuando, a pesar de la similitud en los hechos de las dos tutelas presentadas, el juez constitucional no se ha pronunciado sobre la real pretensión del actor, o cuando la violación se mantiene o se agrava por otras violaciones, como cuando se niega el suministro de un medicamento o cuando se trata de hechos que no habían tenido ocurrencia o no habían sido conocidos por el actor. Como se puede observar, si tras haber interpuesto una tutela por determinados hechos y con determinadas pretensiones, se presentan hechos nuevos imposibles de descubrir antes, que dan lugar a otras pretensiones y que vulneran los derechos fundamentales del actor o de su representado, es posible interponer nuevamente acción de tutela para proteger dichos derechos sin que se configure un caso de temeridad. En estos eventos los supuestos de hecho tienen uno o varios elementos adicionales que permiten la interposición de una nueva acción, siempre y cuando se haya vulnerado nuevamente un derecho fundamental. En conclusión, siempre que haya hechos nuevos, imposibles de preveer con anterioridad y que vulneren o pongan en peligro derechos fundamentales, así ya en ocasiones anteriores se haya interpuesto una acción de tutela, es posible iniciar un nuevo proceso ante la jurisdicción constitucional sin que se configure la temeridad, tal y como ocurre en el caso bajo estudio. ii. El carácter fundamental del derecho a la seguridad social y a la salud. 1. El artículo 48 de la Constitución Política de 1991 establece el derecho a la seguridad social y lo define de la siguiente manera: "La Seguridad Social es un servicio público de carácter obligatorio que se prestará bajo la dirección, coordinación y control del Estado, en sujeción a los principios de eficiencia, universalidad y solidaridad, en los términos que establezca la Ley." Respecto de su carácter fundamental, esta Corte ha reconocido que la satisfacción de su contenido, esto es, del derecho a la pensión y a la salud, implica el goce de las demás libertades del texto constitucional, la materialización del principio de la dignidad humana y la primacía de los derechos fundamentales. Así, es una obligación del Estado garantizar el derecho irrenunciable a la seguridad social de acuerdo con las normas que lo regulan, por cuanto éstas son las que determinan específicamente las prestaciones exigibles y la forma de acceder a las mismas. Deber que correlativamente genera el derecho a los ciudadanos de exigir su cumplimiento en caso de vulneración o amenaza por medio de la acción constitucional de tutela. 2. Por su parte, la salud en la Constitución Política es definida, entre otras calificaciones, como un servicio público a cargo del Estado, un deber del ciudadano de procurar el propio cuidado integral, una garantía a todas las personas al acceso a los servicios de promoción, protección y recuperación (artículo 49), un derecho fundamental de los niños (artículo 44), un servicio garantizado a las personas de la tercera edad (artículo 46), una prestación especializada para los disminuidos físicos, sensoriales y síquicos (artículo 47), un bien constitucionalmente protegido en la comercialización de cosas y servicios (artículo 78) y un valor que se debe proteger respecto de toda persona conforme al principio de solidaridad social (artículo 95). De este modo, la salud constituye un pilar fundamental en el ordenamiento constitucional y ha sido reconocido por esta Corporación como un derecho fundamental susceptible de amparo por medio de la acción constitucional de tutela. 2.1. El carácter fundamental del derecho a la salud radica en que al ser el individuo el centro de la actuación estatal y por ende al generarse frente al Estado la obligación de satisfacción y garantía de los bienes que promuevan su bienestar, la protección del derecho a la 
salud se constituye en una manifestación de bienestar del ser humano y por ende en una obligación por parte del Estado frente a este último. Del mismo modo, el carácter fundamental del derecho a la salud se deriva al constituir su satisfacción un presupuesto para la garantía de otros derechos de rango fundamental. 2.2. El derecho a la salud ha sido definido por esta Corporación como "la facultad que tiene todo ser humano de mantener la normalidad orgánica funcional tanto física como en el plano de la operatividad mental y de restablecerse cuando se presente una perturbación en la estabilidad orgánica y funcional de su ser", que "implica a su vez, la obligación de prestar todos los servicios necesarios para su prevención, promoción, protección y recuperación" (Subraya la Sala). Asimismo, bajo igual lógica de garantizar el bienestar máximo al individuo, se ha señalado que "la salud es 'un estado completo de bienestar físico, mental y social' dentro del nivel posible de salud para una persona. En términos del bloque de constitucionalidad, el derecho a la salud comprende el derecho al nivel más alto de salud posible dentro de cada Estado, el cual se alcanza de manera progresiva". 2.3. Así, la garantía del derecho a la salud incluye el mantenimiento y el restablecimiento de las condiciones esenciales que el individuo requiere para llevar una vida en condiciones de dignidad que le permitan el desarrollo de las diferentes funciones y actividades naturales del ser humano en el marco de su ejercicio del derecho a la libertad. Por lo que ante su vulneración, es un imperativo para el juez constitucional acceder a su amparo a fin de cumplir los objetivos esenciales del Estado, como son el de satisfacer los derechos y promover el bienestar general y el mejoramiento de la calidad de vida de la población en general. 2.4. El derecho a la salud se manifiesta en múltiples formas en relación con las cuales esta Corporación ha tenido oportunidad de pronunciarse y algunas de éstas fueron recopiladas en la sentencia de tutela T-760 de 2008. Entre los elementos que caracteriza el derecho a la salud pertinentes para la resolución de este asunto y sobre los cuales esta Corte se ha pronunciado se encuentran los atinentes a la relación médico-paciente (2.4.1), el cambio de diagnóstico $y$ de procedimiento para el tratamiento de una enfermedad (2.4.2), la continuidad y la integralidad de los servicios de salud (2.4.3) y el principio de no regresividad (2.4.4) que gobierna la regulación de los derechos económicos, sociales y culturales. Bajo este postulado pasa esta Sala a determinar grosso modo el alcance de estos supuestos en el marco del derecho fundamental a la salud. 2.4.1. Con respecto a la relación médico-paciente en sentencia de tutela T-151 de 1996 esta Corte señaló que "[d]ada la delicada misión de quien tiene a su cuidado la salud de los seres humanos y las complejidades propias de la actividad que ella implica, es necesario garantizar no sólo la confianza psicológica del paciente en su médico, y de éste en aquél, sino la efectiva prestación de los servicios profesionales en un clima de transparencia y lealtad que permita lograr el objetivo común de manera eficaz". Y determinó que la experiencia y conocimiento del médico, son las razones que mueven al paciente a acudir en su búsqueda, al confiar en los medicamentos y en los tratamientos que prescribe. Por eso concluyó que los servicios médicos y asistenciales exigen reciproca confianza y mutuo respeto. Es importante mencionar además que, una vez el paciente ha creado un vínculo con su médico tratante, la confianza se convierte en uno de los móviles más importantes de la relación entre ellos. El paciente que confía en su médico ciertamente obtendrá mejores resultados del tratamiento que se le prescribe y tendrá la oportunidad de intervenir en el mismo de manera positiva. Es por esto que, la confianza en el médico es fundamental para que los diferentes tratamientos que requieren los pacientes generen resultados positivos, más aún en el caso de los niños 
con quienes el médico debe lograr una relación cercana que le permita al menor sentirse cómodo y tranquilo durante el tiempo que dure el tratamiento. Se debe resaltar además que no es fácil llegar a esta situación en el caso de niños con problemas de comportamiento y de adaptación y, de lograrse que el menor confíe en sus médicos y se adapte al tratamiento, un cambio repentino en los mismos puede llegar a tener consecuencias negativas en su salud. 2.4.2. En lo que atañe al diagnóstico y a los procedimientos para el tratamiento de una enfermedad, esta Corte ha determinado que los cambios en éstos son amparados por la Constitución, siempre y cuando sea el médico tratante quien haya generado el cambio, y que, lo haya hecho con base en un proceso que hubiera garantizado los derechos a la vida, a la integridad y a la salud del paciente. Esto es, habiendo constatado que el cambio no le va a causar al paciente ningún tipo de perjuicio. Los anteriores supuestos solo se satisfacen si el cambio se fundamenta "en (i) la opinión científica de expertos en la respectiva especialidad y (ii) la historia clínica del paciente, esto es, los efectos que concretamente tendría el tratamiento o el medicamento en el paciente". En otros términos "en caso de cambios, reemplazos o sustituciones médicas, (...) el profesional que recién asume el cuidado del enfermo, avanzadas ya las etapas de medicación puestas en marcha por quienes lo hayan antecedido, no puede ni debe ignorar la integridad de los antecedentes clínicos que rodean el caso". Bajo estos supuestos en sentencia de tutela T-1083 de 2003 se consideró que "Caprecom EPS desconoció los derechos del paciente Aníbal Barrios Reales por cuanto modificó los medicamentos que le había recetado quien fuera su médico tratante sin que su decisión se hubiese fundado en la opinión científica de expertos en la respectiva especialidad que conocieran en detalle la historia clínica del paciente (esto es, los efectos que concretamente tendría el tratamiento o el medicamento en el accionante)" (Subraya la Sala). En este contexto, es relevante señalar que el derecho al diagnóstico es de la esencia del derecho a la salud, pues constituye un presupuesto indispensable para mantener y recuperar el bienestar del individuo, como quiera que este procedimiento permite determinar la condición médica de los posibles pacientes y prescribir un adecuado tratamiento de salud. Asimismo, el derecho al diagnóstico guarda íntima relación con el derecho a la información vital, pues de este modo la persona desarrolla su derecho a controlar su salud y su cuerpo dentro del marco de su derecho fundamental a la autonomía. La Corte ha señalado además que, "para que se continúe con un tratamiento médico o con el suministro de un medicamento, es necesario determinar si la suspensión de los medicamentos viola derechos fundamentales, y para esto se deben cumplir los siguientes requisitos: 1. Debe ser un médico tratante de la EPS quien haya determinado el tratamiento $u$ ordenado los medicamentos; 2. El tratamiento ya se debió haber iniciado, o los medicamentos suministrados (...). Esto significa que debe haber un tratamiento médico en curso. 3. El mismo médico tratante debe indicar que el tratamiento debe continuar o los medicamentos deben seguir siendo suministrados". 2.4.3. La integralidad por su parte atañe a que "(...) la atención y el tratamiento a que tienen derecho los pertenecientes al sistema de seguridad social en salud cuyo estado de enfermedad esté afectando su integridad personal o su vida en condiciones dignas, son integrales; es decir, deben contener todo cuidado, suministro de medicamentos, intervenciones quirúrgicas, prácticas de rehabilitación, exámenes para el diagnóstico y el seguimiento, así como todo otro componente que el médico tratante valore como necesario para el pleno restablecimiento de la salud del paciente o para mitigar las dolencias que le impiden llevar su vida en mejores condiciones; $y$ en tal dimensión, debe ser 
proporcionado a sus afiliados por las entidades encargadas de prestar el servicio público de la seguridad social en salud". En casos en los que se ha requerido el suministro de un tratamiento integral, esta Corte ha tutelado y ordenado éste incluso cuando la IPS que lo ofrece no tiene convenio con la EPS en la cual el accionante está afiliado, o en una de idénticas calidades, especialidad e idoneidad de la IPS sugerida. 3. En estos términos, es una obligación del Estado garantizar el derecho irrenunciable a la seguridad social, de acuerdo con las normas que lo regulan, por cuanto éstas son las que determinan específicamente las prestaciones exigibles y la forma de acceder a las mismas. Con respecto a la salud, el Estado tiene la obligación de ofrecer el servicio de su mantenimiento y recuperación, reconociendo una mayor garantía para sujetos considerados como de especial protección constitucional en razón a sus condiciones particulares que los hacen merecedores de una acción afirmativa Estatal, como lo son los niños, las personas de la tercera edad, los disminuidos físicos, sensoriales y síquicos. La salud es un derecho fundamental amparable por medio de la acción de tutela, pues con su garantía se da protección al individuo, centro de la actuación estatal, y asimismo se garantizan otros derechos de rango fundamental. Este derecho incluye, entre otros aspectos, el tener acceso a los servicios necesarios para recuperar su salud, a obtener un diagnóstico claro, a la continuidad en el tratamiento y los especialistas establecidos por el médico tratante y a la realización de un procedimiento idóneo en el caso en que se decida cambiar un tratamiento. Queda entonces demostrado que, en general, y especialmente en el caso de los niños, el derecho a la seguridad social y el derecho a la salud son derechos fundamentales que implican para el Estado la obligación de la prestación eficiente de los mismos. Así, ante una contingencia en la salud de una persona, a ésta se le debe garantizar el derecho al diagnóstico y posteriormente se le debe prestar un tratamiento integral y completo además de continuo, es decir, con los mismos especialistas y en las mismas instituciones que lo han llevado a cabo, siempre y cuando la EPS respectiva los mantenga y salvo que deban cambiarse los mismos por una modificación en el diagnóstico y tras un procedimiento idóneo del que se pueda inferir la necesidad de dicho cambio. iii. Análisis del caso concreto. Pasa entonces la Sala a analizar el caso concreto para determinar si Coomeva EPS ha vulnerado o no los derechos a la salud y a la seguridad social del menor Sergio Arango Jiménez, al ordenar que parte de su tratamiento, específicamente las sesiones de neuropsicología, debe llevarse a cabo en la ciudad de Pereira y no en la de Manizales que es donde el menor reside con sus padres. 1. Como se deriva de los hechos y del expediente, el niño Sergio Arango Jiménez es un menor de edad que sufre de déficit de atención, problemas neurológicos e hiperactividad, patologías estas que requieren de un tratamiento integral con miras a que la persona que las padece pueda adaptarse de mejor manera al medio social que la rodea. De este modo, el menor en cuestión inició su tratamiento con los doctores y en las instalaciones de Coomeva EPS donde sus médicos tratantes emitieron concepto frente al estado de salud del menor y manifestaron que los niños que sufren de estas patologías son altamente susceptibles a los cambios de ambiente, tales como traslado de domicilio, de profesores, de colegio o de los profesionales que llevan a cabo el proceso de rehabilitación, por lo que no es recomendable cambiar al menor de institución ni de programa. Indicaron además que: "Todos los niños que hacen parte del programa requieren tanto de medicamentos (ritalina) como de una evaluación neuropsicológica, psicológica y psiquiátrica. Además deben iniciar un proceso de intervención con estrategias de modificación de conducta y de control de su atención y de su 
hiperactividad. En estos casos lo más recomendables es que los niños que ya iniciaron un proceso con determinados profesionales continúen con los mismos y no sufran cambios abruptos. Dichos cambios generan altibajos académicos y comportamentales además de interferencias en el contexto familiar, social y escolar". Así mismo, la doctora María Leonor Molina, médica psicóloga especialista en neuropsicopedagogía, presentó un escrito en el que indicó que el procedimiento prescrito al paciente tiene sus bases en terapia cognitiva, manejo del autocontrol corporal y conductal, trabajo específico de terapia ocupacional y fonoaudiología, y que, paralelo a esto debe realizarse también tratamiento con los padres para que ellos aprendan a tratar al niño en la manera adecuada. Manifestó la doctora que la urgencia de la continuidad en el programa era necesaria dados los progresos que ha presentado el menor, y que iniciar el tratamiento en otra institución implicaría volver a empezar todo el proceso lo cual sería perjudicial para la salud del niño quien además tiene unas condiciones emocionales y de adaptación bastante particulares. Indicaron además los profesionales que, si bien las sesiones de neuropsicología que el niño necesita no se encuentran incluidas en el POS, éstas son fundamentales para su recuperación y no existe otro tipo de tratamiento que pueda reemplazarlas. 2. De lo anterior se deriva que efectivamente Sergio Arango Jiménez es un menor que necesita tratamiento integral y que la EPS debe garantizárselo, tanto así que el mismo fue ordenado mediante sentencia de tutela proferida por el Juzgado Sexto Penal Municipal con Función de Control de Garantías de Manizales, Caldas, el 27 de agosto de 2009. En esta oportunidad, el Juzgado ordenó a Coomeva EPS cubrir el tratamiento integral incluyendo las sesiones de neuropsicologia, con la posibilidad de obtener el reintegro ante el Fondo de Solidaridad y Garantías-Fosyga. Sin embargo, una vez proferida la sentencia mencionada anteriormente, Coomeva EPS informó a los padres del menor que efectivamente daría cumplimiento a la misma y cubriría el tratamiento integral del niño, pero que las sesiones de neuropsicología tendrían que llevarse a cabo en la ciudad de Pereira y por profesionales distintos a aquellos que lo habían venido tratando, pese a que los mismos médicos indicaron en repetidas ocasiones que dicho cambio sería perjudicial para el paciente. 3. Nótese entonces que la negativa por parte de la EPS de seguir prestando el tratamiento completo en la ciudad de residencia del menor, constituye un hecho nuevo y completamente diferente a aquellos que dieron lugar a la primera acción de tutela interpuesta por sus padres, hecho además que era imposible de descubrir en el momento de la presentación de la misma. Este nuevo hecho hace entonces posible la presentación de otra acción de tutela en aras de proteger los derechos fundamentales del niño sin que se configure un evento de temeridad. Teniendo en cuenta además que en este caso el sujeto vulnerado no solo está en situación de indefensión por ser menor de edad sino además por padecer de una discapacidad ocasionada por las patologías que padece. 4. Aclarado que no se configura la temeridad en este caso, es procedente entonces recalcar nuevamente que en varias oportunidades esta Corte ha señalado la prestación del servicio de salud debe ser integral, es decir, debe comprender todo cuidado necesario para el restablecimiento de la salud del paciente. Por demás, el tratamiento no solo debe ser integral sino que, en lo posible, debe ser continuo, es decir, en las mismas instituciones y con los mismos profesionales, a menos que haya un cambio en el diagnóstico que implique un cambio de tratamiento. De esta manera, lo ideal es que mientras sea posible, el paciente debe recibir todo el tratamiento de manera uniforme y según el diagnóstico que se le haya dado 
inicialmente, teniendo en cuenta además la enorme influencia que tiene la relación de confianza entre el paciente y su médico tratante, más aún en el caso de los niños. En el caso concreto, la EPS demandada jamás demostró que existiera imposibilidad de seguir prestando el servicio en la ciudad de Manizales y no argumentó su decisión de brindar el tratamiento en la ciudad de Pereira. V. DECISIÓN. En mérito de lo expuesto, la Sala Tercera de Revisión de la Corte Constitucional, administrando justicia en nombre del pueblo y por mandato de la Constitución, RESUELVE. Primero. REVOCAR la sentencia proferida por el Juzgado Segundo Penal Municipal con Función de Control de Garantías de Manizales, de fecha 01 de septiembre de 2010 - única instancia -, por la cual se negó el amparo solicitado por el accionante en contra de Coomeva EPS. Segundo. TUTELAR el derecho a la salud del menor Sergio Arango Jiménez. Tercero. ORDENAR a Coomeva EPS que dentro de las cuarenta y ocho (48) horas siguientes a la notificación del presente fallo autorice que las sesiones de neuropsicología que los doctores María Leonor Molina y Juan Bernardo Zuluaga (médicos tratantes) prescribieron para el menor Sergio Arango Jiménez, se sigan llevando a cabo en la ciudad de Manizales, al menos en las mismas condiciones y con los especialistas que venían desarrollando el tratamiento, en cuanto ello sea posible. Notifíquese, comuníquese, publíquese en la Gaceta de la Corte Constitucional y cúmplase.

Corte Constitucional

Sentencia T-096/11 (Referencia: expediente T-2824666)

Magistrado Ponente: Juan Carlos Henao Pérez

Fecha: 22.2.11

DIREITO À SAÚDE INDÍGENA. Inexistência de violação de direitos coletivos. Serviços de saúde à população Wayu. Inexistência de violação dos direitos coletivos. De acordo com o anterior contexto normativo e probatório, é claro para a Sala que as entidades demandadas cumprem com suas funções constitucionais e legais, como se observa que tanto as instituições prestadoras de saúde IPS, como as Entidades Promotoras de Saúde, proporcionam o estabelecido na normativa. Do exposto, faz concluir que os argumentos apresentados pelos recorrentes não são verdadeiros, pois a população Wayu não está desamparada nos serviços de saúde, razão pela qual a sentença será mantida na sua totalidade. Recursos da parte demandante e do Ministério Público. DECISÃO. PRIMERO: CONFIRMA-SE a sentença apelada. Notifique-se e cumpra-se.

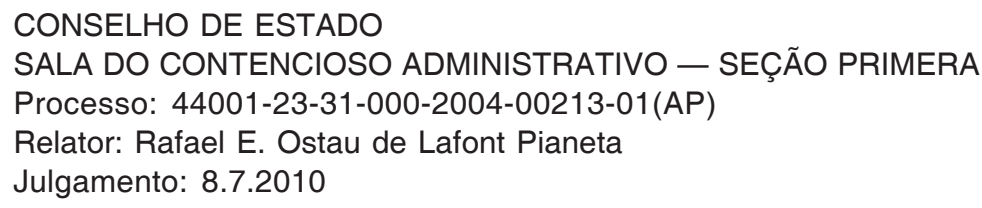

NO VULNERACIÓN DE DERECHOS COLECTIVOS. SERVICIO DE SALUD A LA POBLACIÓN WAYU - No vulneración de derechos colectivos. De acuerdo con el anterior contexto normativo y probatorio, es claro para la Sala que las entidades demandadas cumple con sus funciones constitucionales y legales, pues se observa 
que tantos las Instituciones Prestadoras de Salud IPS, como las Entidades Promotoras de Salud, proporcionan lo establecido en la normativa. De lo anterior, se logra deducir que los argumentos expuesto por los apelantes no son de recibo, pues la población Wayú, no está desamparada en los servicios de salud, razón por la cual la sentencia será confirmada en su totalidad. AUDIENCIA DE PACTO DE CUMPLIMIENTO Inasistencia de las partes. Debe la Sala advertir en torno a las actuaciones que deben surtirse cuando se declara fallida la audiencia de pacto de cumplimiento por la inasistencia de las partes, lo siguiente: En primer lugar, de acuerdo con lo señalado en el artículo 27 de la Ley 472 de 1998, la inasistencia a la citada audiencia por parte de los funcionarios públicos competentes, hará que incurran en causal de mala conducta, sancionable con destitución del cargo. En este caso, deberá darse traslado de las actuaciones pertinentes a la autoridad disciplinaria que sea competente, para que adelante las investigaciones de rigor. En segundo término, tratándose de la parte actora, su inasistencia injustificada a la audiencia especial de pacto de cumplimiento, da lugar a que el juez le imponga las sanciones de ley. En el caso presente la Sala advierte que la audiencia de pacto de cumplimiento se declaró fallida por la inasistencia sin excusa de algunos representantes legales de las entidades Promotoras de la Salud lo cual no puede pasarse por alto. Ahora bien, la Sala instará al Tribunal para que en adelante, cuando ello ocurra, imponga las sanciones previstas en la ley. Así mismo, deberá dar traslado de las piezas procesales pertinentes a la autoridad disciplinaria competente, en caso de que la inasistencia a la citada audiencia sea de las autoridades públicas. FUENTE FORMAL: LEY 472 DE 1998 - ARTÍCULO 27. NOTA DE RELATORIA: Sobre la inasistencia de las partes a la audiencia de pacto de cumplimiento: Consejo de Estado, Sección Primera, sentencias de 30 de agosto de 2007, Rad. 2004-0143 y 2004-0585, MP. Marco Antonio Velilla Moreno. Se deciden los recursos de apelación interpuestos por la parte actora y el Ministerio Público contra la sentencia proferida el 10 de marzo de 2005 por el Tribunal Administrativo de la Guajira, en la cual se negaron las pretensiones de la demanda. I. - LA DEMANDA. 1. Las pretensiones. El 11 de mayo de 2004, la ciudadana Miriam Deluque Semprum promovió demanda en ejercicio de la acción popular contra el Departamento de la Guajira, Municipio de Riohacha, Dusakawi EPSI, Comparta Salud ARS limitada, Caja Salud, Humana Vivir, Caprecon, Asociación Barrios Unidos de Quibdo y Salud Vida, en defensa de los derechos e intereses colectivos relacionados con la moralidad administrativa, la seguridad y salubridad pública, el acceso a los servicios públicos y que su prestación sea eficiente y oportuna, derechos a los consumidores y usuarios, derechos a la salud, vida de la población Wayú, con el fin de que se adoptaran las siguientes disposiciones: "Ordenar al señor Gobernador del Departamento de la Guajira y al alcalde Mayor de Riohacha adelantar y cumplir acciones de vigilancia y control de los factores de riesgo del ambiente que afectan la salud humana a nivel municipal, Departamental al igual que vectores y zoonosis. Además gestiones de coordinación supervisión y control a las actividades de salud pública que hayan realizado y realicen la ARS anteriormente descritas, acompañado de una normal aplicación de los recursos económicos. 2. Disponer y ordenar al Departamento de la Guajira y Municipio de Riohacha estructure un verdadero plan y atención básica en salud, atendiendo a las normas expedidas para tal propósito indicadas en los hechos de la presente demanda a favor de la población Wayú y civilizada. 3. Disponer y ordenar proceso de consulta a la referida comunidades indígenas omitidas, atendiendo el derecho a la libre escogencia y a la concertación a que tiene derecho según la Ley 691 de 2003, Ley 21 de 1991, 
Acuerdo 169 de 1989 de la OIT. (fl. 3 del cuaderno - negrillas y mayúsculas sostenidas del texto original). 2. Los hechos: Como sustento fáctico de la acción se exponen, en síntesis, el siguiente: 1. De acuerdo a una visita realizada por la Dirección General de Salud Pública en octubre de 2003, a la División Departamental de la Guajira, se detectó grave irregularidades y deficiencia que tiene que ver con los procesos de gestión y control de los recursos destinados a dicho plan, concluyéndose que se está afectando la calidad de vida de los habitantes. 2. En cuanto a responsabilidad se refiere es notorio que tanto el Municipio de Riohacha y el Departamento de la Guajira, no han demostrado que han realizado acciones tendientes a garantizar la salud pública en especial a los habitantes Wayú. 3. Se evidencia que el Municipio de Riohacha, a partir del año 2003, no lidera verdaderas acciones de salud de manera programada y suficiente, y mucho menos de promoción y prevención, como lo designó el Acuerdo n. 229 de 2002, demostrándose de esta manera una grave falla en la calida de los servicios de salud, no obstante que es de público conocimiento que la Nación asignó ubicar unos recursos necesarios para tal propósito. 4. La alcaldía de Riohacha, al considerar que los contratos para la administración de recursos del Régimen Subsidiado de Salud, vencieron, suscribió nuevos contratos con las ARS y resolvió designar un comité interdisciplinario encargado de realizar los estudios necesarios, para la contratación de la ARS frente a la administración de Régimen subsidiarios de Salud del Municipio de Riohacha y tomar decisiones sobre las ARS, que van a contratar y números de afiliados, recayendo las respectivas contrataciones a favor de la Asociación Indígena del Cauca, considerando que las ARS incumplieron sus obligaciones contractuales en la prestación del servicio a la comunidad indígena Wayú. II. LAS CONTESTACIONES DE LA DEMANDA. 1. La Asociación Mutual Barrios Unidos de Quibdo E.S.S dio contestación a la misma mediante apoderado, quien manifestó que se opone a sus pretensiones con fundamento en las siguientes razones de defensa: Propuso la excepción de falta de legitimación en la causa por pasiva, como quiera que la omisión endilgada no surge de una actuación u omisión de esta entidad. Afirmó que de los hechos de la demanda y las pretensiones señaladas, son incompatibles con las funciones que desempeñan las diferentes A. R. S., que se encargan de la Administración de los Recursos del Régimen Subsidiado. 2. Por su parte, Comparta Salud A. R. S. avoco conocimiento y propuso la excepción de falta de legitimación en la causa por pasiva, toda vez que la omisión endilgada no surge de una actuación u omisión de la entidad. Afirmó que de los hechos de la demanda y las pretensiones señaladas, son incompatibles con las funciones que desempeñan las diferentes A. R. S., que se encargan de la Administración de los Recursos del Régimen Subsidiado. 3. De igual manera Caprecon E. P. S., a través de su apoderado judicial, precisó que con la actuación desplegada por la alcaldía de Riohacha, con la expedición del informe final y decisión sobre contratación de las A. R. S. para la Administración del Régimen subsidiado en el municipio de Riohacha. 4. El Municipio de Riohacha dio contestación de la demanda mediante apoderado, quien manifestó que se opone a sus pretensiones con fundamento en las siguientes razones de defensa. Señaló que es cierto que el municipio afronta una investigación adelantada por la Superintendecia Nacional de Salud, a raíz de los presuntos malos manejos de los recursos del Régimen Subsidiado; precisamente ese fue una de las razones que tomó la Comisión de legada por el Alcalde, según Resolución n. 0140 de 2004, como fundamento para ordenar el traslado de los Wayú desde las ARS. Indicó que resulta extraño que la Administración Municipal está tomando medidas para proteger a los indígenas Wayú, frente al incumplimiento de las ocho ARS, 
(Dusakawi EPSI, Comparta Salud ARS limitada, Caja Salud, Humana Vivir, Caprecon, Asociación Barrios Unidos de Quibdo y Salud Vida), es cuando a través de una acción popular contra el Gobierno municipal, pidiendo lo que ya se está haciendo. Afirmó que no hay norma vigente que señale que sea función o competencia del alcalde municipal, la concertación con las comunidades indígenas, destacó que las etnias indígenas pueden escoger libremente la ARS a la cual se afilian o trasladan por decisión de sus autoridades legítimas mediante concertación que están hagan dentro de sus comunidades, en la cual se suscribirán actas de acuerdo al procedimiento que ellos mismo determinen. Por lo tanto, si faltó concertación en alguna comunidad, tal hecho es imputable a su autoridad Wayú y no al alcalde. 5. CajaSalud Unión Temporal, S.A. dio contestación a la misma mediante apoderado, quien manifestó que se opone a sus pretensiones y propuso la excepción de falta de legitimación en la causa por pasiva, toda vez que la omisión endilgada no surge de una actuación u omisión de la entidad. 7. La Asociación Indígena del Cauca - AIC Indígena, a través de su apoderado judicial, contestó la demanda, argumentando que las ARS no son encargadas de la Salud pública, esto le corresponde a las entidades territoriales, el Plan de atención básica, complementa las acciones previstas en el plan obligatorio de Salud y las acciones de saneamiento ambiental. Este plan esta constituido por aquellas intervenciones que se dirigen directamente a la colectividad o aquellas que son dirigidas a los individuos. 8. Humana Vivir S.A. EPS, S.A. dio contestación a la misma mediante apoderado, quien manifestó que se opone a sus pretensiones con fundamento en las siguientes razones, indicó que como entidad promotora de Salud en virtud de la Ley 100 de 1993, se encuentra autorizada por el Gobierno Nacional para la administración de los recursos del Régimen Subsidiado mediante Resolución 536 del 27 de marzo de 2001, expedida por la Superintendencia Nacional de Salud; con estas calidades y responsabilidades, celebró contrato con el Municipio de Riohacha, para la prestación de servicios de salud de la población de dicha región, incluyendo la población indígena Wayú para la vigencia de 1 de abril de 2003 a 31 de marzo de 2004. Precisó que Humana Vivir, durante la vigencia de su contrato garantizó los servicios de Salud a la población indígena Wayú, cumpliendo de esta manera, con sus deberes legales y constitucionales, y no como lo pretende hacer valer la demandante. Señaló que el Municipio de Riohacha, suscribió con Humana Vivir, nuevo contrato para la administración de recursos del régimen subsidiado, excluyendo la población indígena, para la vigencia de 1 de abril de 2004 a 31 de marzo de 2005, por ende la responsabilidad como ARS, para la prestación de servicios de salud, frente a dicho grupo ético, cesó a partir del 1 de abril de 2004. Teniendo en cuenta lo anterior, no puede hablarse de violación de derecho colectivo alguno, por cuanto, en la actualidad no existe relación entre Humana Vivir y la población indígena Wayú, por lo cual resulta improcedente ejercer una acción popular sin fundamento jurídico que la soporte. 9. Departamento de la Guajira, dio contestación a la misma mediante apoderado, quien manifestó que se opone a sus pretensiones con fundamento en las siguientes razones de defensa, anotó que ha desarrollado el Plan de Gestión estratégico para el periodo 2004 - 2007, cumpliendo de esta manera con el compromiso que le impone la normativa vigente en cuanto a la seguridad social en salud. III. LA AUDIENCIA DE PACTO DE CUMPLIMIENTO. Atendiendo a lo establecido en el artículo 27 de la Ley 472 de 1998, el Despacho sustanciador convocó a las partes a audiencia de pacto de cumplimiento para el 6 de julio de 2004, la cual se declaró fallida por la ausencia de algunas de las partes demandadas. IV. LOS ALEGATOS DE CONCLUSIÓN. 1. La parte actora: Reiteró los argumentos 
propuestos en la demanda. 2. Las partes demandadas: 2.1. Humana Vivir S.A., reiteró lo planteado en la contestación de la demanda. 2.2. El Departamento de la Guajira, Municipio de Riohacha, Dusakawi EPSI, Comparta Salud ARS limitada, Caja Salud, Caprecon, Asociación Barrios Unidos de Quibdo y Salud Vida, guardaron silencio en esta etapa del proceso. V. LA PROVIDENCIA APELADA. Surtido el trámite de rigor, se profirió la sentencia apelada, en la cual el a quo luego de reseñar la actuación procesal, a la normativa pertinente, y las pruebas obrantes en la actuación, declaró no probas las excepciones propuestas y denegó las suplicas de la demanda, por las siguientes consideraciones: Indicó que a folio 91 a 99 del cuaderno del tribunal, obra copia del estudio, realizado por el Comité interdisciplinario, en el que se informa, que la ARS que actualmente están contratadas por el municipio de Riohacha, han incumplido parcialmente sus obligaciones contractuales en lo relacionado con la prestación de los servicios a la comunidad indígena Wayú. Como consecuencia se ese estudio, se dispuso que toda la población de afiliados de la comunidad Wayú, será atendida por la ARS, Asociación Indígena del Cauca. Esta decisión de traslado fue adoptada como mecanismo correctivo y en procura de un mejor servicio para los beneficiarios del mismo. Anotó que en el cuaderno de pruebas, contiene un informe Técnico del Plan de tención Básica Departamental en Salud, desde el año 2003, lo que es indicativo, que sí existe en el departamento unos estudios y planes en relación con los servicios de salud, por consiguiente, conforme a las pruebas aludidas, esa entidad territorial si cumple con las funciones que en esa materia le imponen las leyes y los reglamentos. VI. LOS RECURSOS. Inconforme con la anterior decisión la parte demandante y el Ministerio Público la apelaron, con apoyo en las siguientes argumentaciones: 1. La parte demandante, reiteró que el Municipio de Riohacha y la Gobernación del Departamento de la Guajira, no han cumplido con las acciones de promoción de salud, prevención de enfermedades y vigilancia a la salud pública para prevenir los factores de riesgo ambiental, que amenazan y afectan a la población indígena, niños, ancianos, frente a esta situación se detectó a su ves graves irregularidades y deficiencia, por parte de la Dirección General de la Salud Pública, según visita realizada en octubre de 2003. Motivos suficientes para acceder a las súplicas de la demanda: 2. EI Ministerio Público, se aparta de la sentencia, pues las investigaciones administrativas de la Superintendencia Nacional de Salud por la decisión de adoptada por el alcalde municipal de Riohacha, de trasladar los indígenas como afiliados para la Asociación Indígena del Cauca, no pueden tenerse como pruebas de vulneración o amenaza de los derechos e intereses colectivos de la población indígena y civilizada, destinataria de los recursos del régimen de salud subsidiado. Destacó que el Tribunal debió analizar y debatir el por que $y$ en que pruebas se basaron las entidades territoriales, para presumir que el Municipio de Riohacha, sí realizó mecanismos de control, vigilancia y supervisión. VII. CONSIDERACIONES DE LA SALA. 1. El artículo $2^{\circ}$, inciso segundo, de la Ley 472 de 1998, en desarrollo del artículo 88 de la Constitución Política, dispone que las acciones populares se ejercen para evitar el daño contingente, hacer cesar el peligro, la amenaza, la vulneración o agravio sobre los derechos e intereses colectivos, o restituir las cosas a su estado anterior cuando fuere posible; y al tenor del artículo $9^{\circ}$ ibídem, esas acciones proceden contra toda acción u omisión de las autoridades públicas o de los particulares, que hayan violado o amenacen violar los derechos e intereses colectivos. De acuerdo con lo anterior, se tiene que los supuestos sustanciales para que proceda la acción popular son los siguientes, a saber: a) una acción u omisión de la parte demandada, b) un daño contingente, peligro, amenaza, 
vulneración o agravio de derechos o intereses colectivos, peligro o amenaza que no es en modo alguno el que proviene de todo riesgo normal de la actividad humana $y, c)$ la relación de causalidad entre la acción u omisión y la señalada afectación de tales derechos e intereses; dichos supuestos deben ser demostrados de manera idónea en el proceso respectivo. 2. Con el ejercicio de la presente acción se pretende la protección de los derechos e intereses colectivos relacionados con el con la moralidad administrativa, la seguridad y salubridad pública, el acceso a los servicios públicos a que su prestación sea eficiente y oportuna, derechos a los consumidores y usuarios, derechos a la salud, vida de la población Wayú. En ese contexto, solicita la demandante que a través de la acción de la referencia se ordene al señor Gobernador del Departamento de la Guajira y al alcalde Mayor de Riohacha adelantar y cumplir acciones de vigilancia y control de los factores de riesgo del ambiente que afectan la salud humana a nivel municipal, Departamental, al igual que vectores y zoonosis. Además realizar gestiones de coordinación supervisión y control a las actividades de salud pública que hayan realizado y realicen la ARS; igualmente disponer y ordenar al Departamento de la Guajira y al Municipio de Riohacha estructuré un verdadero plan y atención básica en salud, atendiendo a las normas expedidas para tal propósito indicadas en los hechos de la presente demanda a favor de la población Wayú y civilizada. 3. El a quo en la sentencia impugnada negó las pretensiones de la demanda al estimar que no encuentran vulnerados los derechos colectivos invocados por la demandante. 4. La actora y el Ministerio Público apelan la anterior decisión, la primera reiterando que las entidades territoriales demandas, no han cumplido con las acciones de promoción de salud, prevención de enfermedades y vigilancia a la salud pública para prevenir los factores de riesgo ambiental que afectan lo población indígena; y la segunda precisa que las entidades demandadas no están cumpliendo con la obligación de controlar y vigilar las administradoras al régimen subsidiario en salud a los indígenas. 6. Corresponde, entonces, a la Sala determinar si en efecto las entidades territoriales demandas, han incurrido o no; en las omisiones de su funciones en la prestación del servicio de salud a los indígenas Wayú. 7. En orden a resolver lo pertinente, se precisa que el artículo 25 de la Ley 21 del 4 de marzo de 1991 "Por medio de la cual se aprueba el Convenio número 169 sobre pueblos indígenas y tribales en países independientes, adoptado por la $76^{\underline{a}}$ reunión de la Conferencia General de la OIT, Ginebra 1989" dispone lo siguiente: "Artículo 25. 1. Los gobiernos deberán velar porque se pongan a disposición de los pueblos interesados servicios de salud adecuados o proporcionar a dichos pueblos los medios que les permitan organizar y prestar tales servicios bajo su propia responsabilidad y control, a fin de que puedan gozar del máximo nivel posible de salud física y mental. 2. Los servicios de salud deberán organizarse, en la medida de lo posible, a nivel comunitario. Estos servicios deberán planearse y administrarse en cooperación con los pueblos interesados y tener en cuenta sus condiciones económicas, geográficas, sociales y culturales, así como sus métodos de prevención, prácticas curativas y medicamentos tradicionales. 3. El sistema de asistencia sanitaria deberá dar la preferencia a la formación y al empleo de personal sanitario de la comunidad local y centrarse en los cuidados primarios de salud, mantenimiento al mismo tiempo estrechos vínculos con los demás niveles de asistencia sanitaria. 4. La prestación de tales servicios de salud deberá coordinarse con las demás medidas sociales, económicas y culturales que se tomen en el país". 8. Así mismo, los artículos 153, 156 de la Ley 100 de 1993, dispone en lo pertinente lo siguiente: "ARTÍCULO 153. FUNDAMENTOS DEL SERVICIO PÚBLICO. 
Además de los principios generales consagrados en la Constitución Política, son reglas del servicio público de salud, rectoras del Sistema General de Seguridad Social en Salud las siguientes: 1. Equidad. El Sistema General de Seguridad Social en Salud proveerá gradualmente servicios de salud de igual calidad a todos los habitantes en Colombia, independientemente de su capacidad de pago. Para evitar la discriminación por capacidad de pago o riesgo, el Sistema ofrecerá financiamiento especial para aquella población más pobre y vulnerable, así como mecanismos para evitar la selección adversa. 2. Obligatoriedad. La afiliación al Sistema General de Seguridad Social en Salud es obligatoria para todos los habitantes en Colombia. En consecuencia, corresponde a todo empleador la afiliación de sus trabajadores a este Sistema y del Estado facilitar la afiliación a quienes carezcan de vínculo con algún empleador o de capacidad de pago. 3. Protección integral. El Sistema General de Seguridad Social en Salud brindará atención en salud integral a la población en sus fases de educación, información y fomento de la salud y la prevención, diagnóstico, tratamiento y rehabilitación, en cantidad, oportunidad, calidad y eficiencia de conformidad con lo previsto en el artículo 162 respecto del Plan Obligatorio de Salud. 4. Libre escogencia. El Sistema General de Seguridad Social en Salud permitirá la participación de diferentes entidades que ofrezcan la administración y la prestación de los servicios de salud, bajo las regulaciones y vigilancia del Estado y asegurará a los usuarios libertad en la escogencia entre las Entidades Promotoras de Salud y las Instituciones Prestadoras de Servicios de Salud, cuando ello sea posible según las condiciones de oferta de servicios. Quienes atenten contra este mandato se harán acogedores a las sanciones previstas en el artículo 230 de esta Ley. 5. Autonomía de instituciones. Las instituciones prestadoras de servicios de salud tendrán, a partir del tamaño y complejidad que reglamente el gobierno, personería jurídica, autonomía administrativa y patrimonio independiente, salvo los casos previstos en la presente Ley. 6. Descentralización administrativa. La organización del Sistema General de Seguridad Social en Salud será descentralizada y de ella harán parte las direcciones seccionales, distritales y locales de salud. Las instituciones públicas del orden nacional que participen del sistema adoptarán una estructura organizacional, de gestión y de decisiones técnicas, administrativas y financieras que fortalezca su operación descentralizada. 7. Participación social. El Sistema General de Seguridad Social en Salud estimulará la participación de los usuarios en la organización y control de las instituciones del Sistema General de Seguridad Social en Salud y del sistema en su conjunto. El Gobierno Nacional establecerá los mecanismos de vigilancia de las comunidades sobre las entidades que conforman el sistema. Será obligatoria la participación de los representantes de las comunidades de usuarios en las juntas directivas de las entidades de carácter público. "ARTÍCULO 156. CARACTERÍSTICAS BÁSICAS DEL SISTEMA GENERAL DE SEGURIDAD SOCIAL EN SALUD. El Sistema General de Seguridad Social en Salud tendrá las siguientes características: a) El Gobierno Nacional dirigirá, orientará, regulará, controlará y vigilará el servicio público esencial de salud que constituye el Sistema General de Seguridad Social en Salud; b) Todos los habitantes en Colombia deberán estar afiliados al Sistema General de Seguridad Social en Salud, previo el pago de la cotización reglamentaria o a través del subsidio que se financiará con recursos fiscales, de solidaridad y los ingresos propios de los entes territoriales; c) Todos los afiliados al Sistema General de Seguridad Social en Salud recibirán un Plan Integral de protección de la salud, con atención preventiva, médico-quirúrgica y medicamentos esenciales, que será denominado el Plan Obligatorio de Salud; d) El 
recaudo de las cotizaciones será responsabilidad del Sistema General de Seguridad Social-Fondo de Solidaridad y Garantía, quien delegará en lo pertinente esta función en las Entidades Promotoras de Salud; e) Las Entidades Promotoras de Salud tendrán a cargo la afiliación de los usuarios y la administración de la prestación de los servicios de las Instituciones Prestadoras. Ellas están en la obligación de suministrar, dentro de los límites establecidos en el numeral 5 del artículo 180, a cualquier persona que desee afiliarse y pague la cotización o tenga el subsidio correspondiente, el Plan Obligatorio de Salud, en los términos que reglamente el gobierno; f) Por cada persona afiliada y beneficiaria, la Entidad Promotora de Salud recibirá una Unidad de Pago por Capitación - UPC - que será establecida periódicamente por el Consejo Nacional de Seguridad Social en Salud; g) Los afiliados al sistema elegirán libremente la Entidad Promotora de Salud, dentro de las condiciones de la presente Ley. Así mismo, escogerán las instituciones prestadoras de servicios y/o los profesionales adscritos o con vinculación laboral a la Entidad Promotora de Salud, dentro de las opciones por ella ofrecidas; h) Los afiliados podrán conformar alianzas o asociaciones de usuarios que los representarán ante las Entidades Promotoras de Salud y las Instituciones Prestadoras de Servicios de Salud; i) Las Instituciones Prestadoras de Salud son entidades oficiales, mixtas, privadas, comunitarias y solidarias, organizadas para la prestación de los servicios de salud a los afiliados del Sistema General de Seguridad Social en Salud, dentro de las Entidades Promotoras de Salud o fuera de ellas. El Estado podrá establecer mecanismos para el fomento de estas organizaciones y abrir líneas de crédito para la organización de grupos de práctica profesional y para las Instituciones Prestadoras de Servicios de tipo comunitario y Solidario; j) Con el objeto de asegurar el ingreso de toda la población al Sistema en condiciones equitativas, existirá un régimen subsidiado para los más pobres y vulnerables que se financiará con aportes fiscales de la Nación, de los departamentos, los distritos y los municipios, el Fondo de Solidaridad y Garantía y recursos de los afiliados en la medida de su capacidad; k) Las Entidades Promotoras de Salud podrán prestar servicios directos a sus afiliados por medio de sus propias Instituciones Prestadoras de Salud, o contratar con Instituciones Prestadoras y profesionales independientes o con grupos de práctica profesional, debidamente constituidos; o) Las entidades territoriales celebrarán convenios con las Entidades Promotoras de Salud para la administración de la prestación de los servicios de salud propios del régimen subsidiado de que trata la presente Ley. Se financiarán con cargo a los recursos destinados al sector salud en cada entidad territorial, bien se trate de recursos cedidos, participaciones o propios, o de los recursos previstos para el Fondo de Solidaridad y Garantía. Corresponde a los particulares aportar en proporción a su capacidad socioeconómica en los términos y bajo las condiciones previstas en la presente Ley; p) La Nación y las entidades territoriales, a través de las instituciones hospitalarias públicas o privadas en todos los niveles de atención que tengan contrato de prestación de servicios con él para este efecto, garantizarán el acceso al servicio que ellas prestan a quienes no estén amparados por el Sistema General de Seguridad Social en Salud, hasta cuando éste logre la cobertura universal. 9. De otra parte como elementos probatorios en el expediente se encuentran los siguientes: - A folios 91 a 100 del cuaderno del tribunal se observa copia del informe final y decisión sobre la contratación de las ARS, para la Administración del Régimen Subsidiado del Municipio de Riohacha, en el cual se tomó la siguiente decisión: "Primera: Todos los indígenas afiliados al Régimen Subsidiado de Salud en el Municipio de Riohacha, hasta el 31 de marzo de 2004, a las ARS 
Dusakawi EPSI, Comparta Salud ARS limitada, Caja Salud, Anas Wayú EPSI, Humana Vivir, Caprecon, Asociación Barrios Unidos de Quibdo y Salud Vida, serán trasladados a la ARS Asociación Indígena del Cauca - AIC EPS Indígena, la cual será contratada para la atención de todos los indígenas afiliados al régimen subsidiado de salud en el Municipio de Riohacha. "Segunda: En consecuencia, las ARS ARS Dusakawi EPSI, Comparta Salud ARS limitada, Caja Salud, Anas Wayú EPSI, Humana Vivir, Caprecon, Asociación Barrios Unidos de Quibdo y Salud Vida, seguirán funcionando y serán contratadas con el resto de afiliados no indígenas, haciendo a cada una de ellas deducciones de los afiliados indígenas que por virtud de esta decisión se trasladan a la ARS Asociación Indígena del Cauca - AIC. EPS INDÍGENA. - A folios 162 a 168 del cuaderno del tribunal, obra copia del contrato de prestación de servicio n. 035-2004 plan obligatorio de salud - subsidiado recuperación de la salud detención temprana y protección especifica primer y segundo nivel y baja y mediana complejidad, suscrito entre la Asociación Indígena del Cauca y la IPS Hospital nuestra señora de los remedios. - A folios 169 a 173 del cuaderno del tribunal, se observa copia del contrato de prestación de servicios de salud n. 050 2004, suscrito entre la Asociación Indígena del Cauca y el Centro de Diagnostico de Especialistas Ltda. Cedes Riohacha - Guajira. - A folios 172 a 182 del cuaderno del tribunal obra copia del contrato de prestación de salud n. 058-2004 entre la Asociación Indígena del cauca y Unidad de Cuidados intensivos - Riohacha - Guajira. - A folios 183 a 186 del cuaderno del tribunal obra copia del contrato de suministro de medicamentos n. 059-2002 celebrado entre la Asociación Indígena del Cauca y Droguería Migeshalin - Riohacha - Guajira. 10. De acuerdo con el anterior contexto normativo y probatorio, es claro para la Sala que las entidades demandadas cumple con sus funciones constitucionales y legales, pues se observa que tantos las Instituciones Prestadoras de Salud IPS, como las Entidades Promotoras de Salud, proporcionan lo establecido en la normativa. 11. De lo anterior, se logra deducir que los argumentos expuestos por los apelantes no son de recibo, pues la población Wayú, no está desamparada en los servicios de salud, razón por la cual la sentencia será confirmada en su totalidad. 12. Finalmente, debe la Sala advertir en torno a las actuaciones que deben surtirse cuando se declara fallida la audiencia de pacto de cumplimiento por la inasistencia de las partes, lo siguiente: En primer lugar, de acuerdo con lo señalado en el artículo 27 de la Ley 472 de 1998, la inasistencia a la citada audiencia por parte de los funcionarios públicos competentes, hará que incurran en causal de mala conducta, sancionable con destitución del cargo. En este caso, deberá darse traslado de las actuaciones pertinentes a la autoridad disciplinaria que sea competente, para que adelante las investigaciones de rigor. En segundo término, tratándose de la parte actora, su inasistencia injustificada a la audiencia especial de pacto de cumplimiento, da lugar a que el juez le imponga las sanciones de ley. Esta Sala en reiterada jurisprudencia ha puesto de presente que la inasistencia del actor popular a la audiencia de pacto de cumplimiento obliga al a quo a imponerle las sanciones previstas en la Ley. Ha dicho la Sala: "En sentencia del 25 de agosto de 2001 proferida por la Sección Primera del Consejo de Estado dentro de la AP-1500123-31-000-2000-2099-01, con ponencia del Consejero Dr. Gabriel Eduardo Mendoza Martelo, se precisó que del texto del artículo antes trascrito (artículo 27 de la Ley 472 de 1998) claramente se advierte que para efectos de la audiencia especial de pacto de cumplimiento la Ley 472 de 1998 únicamente previó que la inasistencia a la misma por parte de los funcionarios competentes, constituía causal de mala conducta, sancionable con la destitución del cargo. Sin embargo, el artículo 44, ibídem, señala que en los procesos por acciones populares se aplicarán las disposiciones del Código de 
Procedimiento Civil y del Código Contencioso Administrativo, dependiendo de la jurisdicción que le corresponda, en los aspectos no regulados en la presente Ley, mientras no se opongan a la naturaleza y finalidades de tales acciones', lo cual, en principio, permite considerar que el juzgador está autorizado para acudir a otras disposiciones que sí prevén la sanción pecuniaria como consecuencia de la inasistencia a una audiencia o diligencia, verbigracia, el artículo 74 de la Ley 446 de 1998, 101 del CPC, o el artículo 114 del CCA. Claro está, que no puede perderse de vista que además de esas normas, citadas a manera de ejemplo en sentencia proferida en el año 2001 para resolver ese caso concreto en ese momento y en lo que resultare pertinente, también cabe tener presente el artículo 39 del CPC relacionado con los poderes disciplinarios del juez, en virtud de cuyo numeral $1^{\circ}$ dicho funcionario puede 'sancionar con multas de dos a cinco salarios mínimos mensuales a sus empleados, a los demás empleados públicos, y a los particulares que sin justa causa incumplan las órdenes que les imparta en ejercicio de sus funciones o demoren su ejecución". Esto cobra más importancia si se concibe a la audiencia de pacto de cumplimiento como la primera oportunidad para lograr la reivindicación del derecho colectivo conculcado, materializándose así esa naturaleza altruista propia de la acción popular que igualmente debe caracterizar a quien la ejerce, y por tanto desprovista de todo interés económico. Posteriormente, en sentencia del 6 de octubre de 2005, proferida dentro de la acción popular 90074, con ponencia de la Consejera Dra. María Claudia Rojas Lasso, se dispuso: 'Advierte la Sala, que en adelante, en caso de no asistencia de la parte actora a la audiencia de Pacto de Cumplimiento deberá el a-quo imponer a ésta las sanciones previstas en la ley.' A partir de tal precedente se ha venido advirtiendo que la inasistencia del actor a la audiencia de pacto de cumplimiento, sin que se excusara por ello o la justificara, no debe pasarse por alto, razón por la cual ha encontrado necesario recordar que, en adelante, cuando ello ocurra, se tiene el deber de imponer las sanciones previstas en la ley." En el caso presente la Sala advierte que la audiencia de pacto de cumplimiento se declaró fallida por la inasistencia sin excusa de algunos representantes legales de las entidades Promotoras de la Salud lo cual no puede pasarse por alto. Ahora bien, la Sala instará al Tribunal para que en adelante, cuando ello ocurra, imponga las sanciones previstas en la ley. Así mismo, deberá dar traslado de las piezas procesales pertinentes a la autoridad disciplinaria competente, en caso de que la inasistencia a la citada audiencia sea de las autoridades públicas. En mérito de lo expuesto, el Consejo de Estado, Sala de lo Contencioso Administrativo, Sección Primera, administrando justicia en nombre de la República y por autoridad de la ley, FALLA. PRIMERO: CONFÍRMASE la sentencia apelada. SEGUNDO: EXHÓRTASE al a quo para que en adelante, en caso de inasistencia injustificada de la parte actora a la audiencia de pacto de cumplimiento, imponga las sanciones previstas en la ley. Así mismo, deberá dar traslado de las piezas procesales pertinentes a la autoridad disciplinaria competente, en caso de que la inasistencia a la citada audiencia sea de las autoridades públicas. Notifíquese y cúmplase, RAFAEL E. OSTAU DE LAFONT PIANETA. MARÍA CLAUDIA ROJAS LASSO. Presidente. MARCO ANTONIO VELILLA MORENO

\section{CONSEJO DE ESTADO \\ SALA DE LO CONTENCIOSO ADMINISTRATIVO - SECCIÓN PRIMERA}

Radicación número: 44001-23-31-000-2004-00213-01(AP)

Consejero ponente: Rafael E. Ostau de Lafont Pianeta

Fecha: 8.7.10 